Camila Bonin Pinto

\title{
Efeito da desregulação da via UPR sobre a expressão da ciclina A1 em linfócitos B humanos
}

Dissertação apresentada ao Programa de PósGraduação em Imunologia do Instituto de Ciências Biomédicas da Universidade de São Paulo, para a obtenção do Título de Mestre em Ciências. 


\section{Efeito da desregulação da via UPR sobre a expressão da ciclina A1 em linfócitos B humanos}

Dissertação apresentada ao Programa de PósGraduação em Imunologia do Instituto de Ciências Biomédicas da Universidade de São Paulo, para a obtenção do Título de Mestre em Ciências.

Área de concentração: Imunologia

Orientador:

Profa. Dra. Maristela Martins de Camargo

Versão corrigida. A versão original eletrônica encontra-se disponível tanto na Biblioteca do ICB quanto na Biblioteca Digital de Teses e Dissertações da USP (BDTD). 
DADOS DE CATALOGAÇĀO NA PUBLICAÇĀO (CIP)

Serviço de Biblioteca e Informaçăo Biomédica do

Instituto de Cièncias Biomédicas da Universidade de Săo Paulo

reproduçăo năo autorizada pelo autor

Pinto, Camila Bonin.

Efeito da desregulação da via UPR sobre a expressāo da ciclina A1 em linfócitos B humanos / Camila Bonin Pinto. -- Sāo Paulo, 2012

Orientador: Profa. Dra. Maristela Martins de Camargo.

Dissertação (Mestrado) - Universidade de São Paulo. Instituto de Ciências Biomédicas. Departamento de Imunologia. Área de concentração: Imunologia. Linha de pesquisa: Via unfolded protein response.

Versão do titulo para o inglès: Effect of the deregulation of the UPR pathway in the expression of cyclin A1 in human B lymphocytes.

1. UPR 2. Linfócitos B 3. CVID 4. Ciclo celular I. Camargo, Profa Dra. Maristela Martins de II. Universidade de São Paulo. Instituto de Ciências Biomédicas. Programa de Pós-Graduação em Imunologia III. Titulo. 
UNIVERSIDADE DE SÃO PAULO

INSTITUTO DE CIENNCIAS BIOMÉDICAS

Candidato(a): $\quad$ Camila Bonin Pinto.

Título da Efeito da desregulaçăo da via UPR sobre a expressäo da ciclina A1 em linfócitos B humanos.

Orientador(a): $\quad$ Profa. Dra. Maristela Martins de Camargo.

A Comissăo Julgadora dos trabalhos de Defesa da Dissertação de Mestrado, em sessão pública realizada a .........

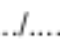
considerou
( ) Aprovado(a)
( ) Reprovado(a)

\begin{abstract}
Examinador(a): Assinatura:
Nome:

Instituição:

Examinador(a): Assinatura:

Nome:

Instituição:

Presidente: Assinatura:

Nome:

Instituição:
\end{abstract}


Cidade Universitária "Armando de Salles Oliveira"

São Paulo, 10 de novembro de 2010.

\section{PARECER 973/CEP}

A Comissão de Ética em Pesquisas com Seres Humanos do ICB, em 10.11.2010, APROVOU o projeto intitulado: "Efeito da desregulação da via UPR sobre a expressão da ciclina A1 em linfócitos B humanos" sob responsabilidade de execução dos autores Profa. Dra. Maristela Martins de Camargo e a aluna Camila Bonin Pinto.

Cabe aos pesquisadores executantes elaborar e apresentar a este Comitê, relatórios anuais (parciais ou final), de acordo com a resolução 196/06 do Conselho Nacional da Saúde, item IX. 2 letra c.

O primeiro relatório deverá ser encaminhado à Secretaria deste CEP em

10.11.2011.

Atenciosamente,

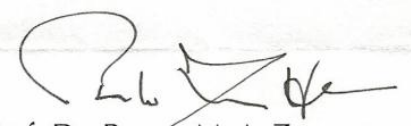

Prof. Dr. PAOLO M. A. ZANOtTO

Coordenador da Comissão de Ética em

Pesquisas com Seres Humanos - ICB/USP

Comissão de Ética em Pesquisa com Seres Humanos do Instituto de Ciências Biomédicas / USP Aprovada pela Comissão Nacional de Ética em Pesquisa - CONEP, em 10 de fevereiro de 1998. 
Cidado Universitiaia "Asmando de Salles Oltreirg"

Decl. CEPSH.054/11.

\author{
DECLARACÄO
}

Fim adendo an Parecer 973/C.F.P, de 10-novembro-2010), declaro que esta Comissão näo faz restrições às alteraçōes propostas para o Projeto

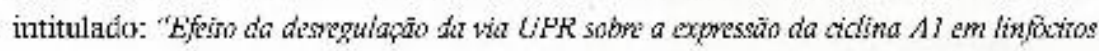
$\pi$ humanes" sob responsabilidade dos autores Profa. Dra. MAristka A MarTivs IJ Camargo e a aluna Camula Bonin Pinto, pois as mesmas não afetam us aspectos éticos da pesquisa.

São Paulo, 29 de setembro de 2011.

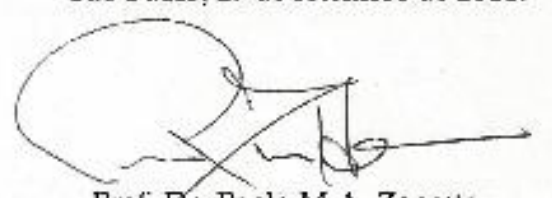

Prof. Dr. Panlo M.A. Zanoulo

Coordenador da Comissäo de Ética em Pesquisas com Seres Humanos - ICB /USP

Comissáo de Ética cm Pesquisa com Seres Hunanos do Instituto de Ciéncias Blomédlcas - USP Aproveda pela Comissác Nacional de Ética em Pasquisa - CONFP, em 10 de. tevereim de 14g8. 
Dedico este trabalho à minha família, Domingos, Rosana, Carolina e Leon pelo grande incentivo, dedicação e carinho. 


\section{AGRADECIMENTOS}

À minha orientadora, Prof ${ }^{a}$. Dr ${ }^{\mathrm{a}}$. Maristela Martins de Camargo, por ter aberto as portas do seu laboratório e permitido que eu ingressasse em sua equipe, pela sua valiosa orientação, incentivo, confiança, ensinamentos, dedicação e paciência.

À minha família,

Aos meus pais, pela excelente formação que me deram, além do amor e carinho que sempre dedicaram a mim. Não há palavras que expressem o meu profundo sentimento de gratidão. À minha irmã, Carol, pelo apoio, carinho, incentivo e presença em todos os momentos.

Ao Leon, companheiro e amigo, por todo amor e carinho, pelas conversas, risadas, discussões e principalmente pela paciência e disposição em me ouvir.

À Leda e Luciana, por estarem sempre ao meu lado e torcendo pelas minhas conquistas.

A toda a minha família, tios, primos e, principalmente, à minha avó Neide, pelas orações e carinho.

Aos colaboradores

À Profa. Dra. Cristina Kokron do Serviço de Imunologia e Alergia do Hospital de Clínicas da Universidade de São Paulo, que viabilizou a coleta das amostras dos pacientes.

À técnica de enfermagem Rosana, pela coleta das amostras dos pacientes.

À Profa. Dra. Luiza Guilherme Guglielmi, pela imortalização dos linfócitos B.

À Dra. Mirsada Imamovic, pelos reagentes cedidos que auxiliaram a realização desse projeto.

Ao Paciente $\mathrm{P}$, por ser sempre tão solicito e simpático. 
Aos professores José Alexandre Barbuto, Sergio Schenkman e Irene Yan, pela grande contribuição no exame de qualificação.

Aos amigos do Departamento de Imunologia,

Aos colegas de laboratório que estiveram presentes ao longo deste projeto: Bruno Miotto, Camila Domingues de Oliveira, Susana Rosa, Cauê Zortéa, Carla Patrícia Amorin e Fernanda Sodré pela amizade, companheirismo e carinho, ajuda e pelas discussões sobre diversos protocolos.

À Michele e Tatiana, dois anjos que me ensinaram o valor de uma verdadeira amizade. Pelo carinho e apoio em todas as horas e por terem sido fundamentais para a realização deste projeto.

À Fernanda e Susana, companheiras de trabalho com as quais continuo aprendendo a compartilhar conhecimentos e ideias e que me ensinam muito. Obrigada pelo apoio, pelo carinho, conversas, risadas, horas de bancada, pela ajuda em diversos experimentos e por tudo que aprendi com vocês.

Às amigas, Samantha, Tarsila, Laura Sette, Elisa, Maira, Natalia, Thais, Laura Canal e Fernanda por fazerem esses anos serem inesquecíveis. Obrigada pelo apoio e carinho, que essa amizade dure para sempre.

Aos amigos do Departamento de Imunologia do ICB - USP, em especial Bruna Bizzarro, Dani, Ceres, Mari Koga, Karen, Isabela, Bruna Zelanter, Grazi, Esther, Mônica, Adriana, Dani e Renan, pela amizade e pelas experiências compartilhadas.

Aos docentes do Departamento de Imunologia do ICB - USP, por todos os ensinamentos e pela disponibilidade em compartilhar reagentes e equipamentos.

A todos os funcionários do Departamento de Imunologia do ICB - USP por contribuírem de uma forma ou de outra para a realização deste projeto.

Muito obrigada a todos que de alguma maneira contribuíram para este trabalho! 
Este trabalho foi realizado com o apoio da Fundação de Amparo à Pesquisa do Estado de São Paulo (FAPESP) e Conselho Nacional de Pesquisa e Desenvolvimento (CNPq) 
The show must go on, Inside my heart is breaking My make-up may be flaking But my smile still stays on Queen 


\section{RESUMO}

Pinto BP. Efeito da desregulação da via UPR sobre a expressão de ciclina A1 em linfócitos B humanos. [dissertação (Mestrado em Imunologia)]. São Paulo: Instituto de Ciências Biomédicas, Universidade de São Paulo; 2012.

A via Unfolded Protein Response (UPR) é uma via de sinalização ativada pelo estresse do Retículo endoplasmático (ER). Existem três sensores presentes no ER que detectam a presença de proteínas não dobradas: IRE $\alpha$, PERK e ATF6. Anteriormente foi descrito um paciente com Imunodeficiência Comum Variável (CVID) que apresenta um atraso na ativação da via UPR associado com o acúmulo de imunoglobulinas dentro do ER. Linfócitos B imortalizados pelo vírus Epsein Barr (EBV-B) desse e de outros pacientes com CVID apresentam uma taxa de proliferação diminuída quando comparados com EBV-B de doadores saudáveis. A Ciclina A1 é uma proteína envolvida na regulação do ciclo celular e tem a expressão aumentada quando ocorre a indução do IRE1 $\alpha$, sugerindo uma regulação entre o ciclo celular e o estresse do ER. Nosso principal objetivo foi analisar se o estresse do ER pode alterar o ciclo celular dos linfócitos B dos pacientes com CVID e de controles saudáveis. Para investigar a relação da UPR com o ciclo celular, estabelecemos um sistema no qual drogas estressoras do ER foram usadas para ativar a via UPR, seguido de análises de ciclo celular, apoptose e expressão relativa de genes associados a via UPR em diferentes linhagens de linfócitos B e em células ex vivo. Cada amostra foi analisada por citometria de fluxo, PCR em tempo real e RT-PCR. Nossos resultados demonstram que a ativação crônica da UPR interrompe o ciclo celular de EBV-B através da quebra da natureza cíclica da Ciclina A1. Sob a ativação crônica do ER, a expressão de Ciclina A1 se manteve elevada por até $24 \mathrm{~h}$ de cultura. Como consequiência observamos o aumento do número de células nas fase $\mathrm{S}$ ou $\mathrm{G} 1$ do ciclo celular. Essa parada foi dependente da linhagem EBV-B estudada e da droga utilizada. Além disso, a ativação crônica da UPR aumenta a apoptose através da ativação do braço da PERK da via UPR aumentando a expressão do fator pró-apoptótico CHOP. Células ex vivo e EBV-B do paciente $\mathrm{P}$ também foram analisadas e apresentaram uma taxa metabólica muito baixa e número aumentado de células em apoptose. Não foi possível observar as alterações do ciclo celular nas células do paciente devido à falta de resposta proliferativa frente aos diferentes estímulos. Entretanto, observamos que a deficiência da resposta do paciente $\mathrm{P}$ frente à ativação da via UPR parece ser no reconhecimento de proteínas não dobradas. Isso porque os linfócitos $\mathrm{B}$ do paciente esboçam uma resposta quando o estresse do ER é gerado por drogas como a tapsigargina e a brefeldina $\mathrm{A}$, mas não pelo DTT. Nossos resultados sustentam a hipótese de que a proliferação deficiente observada no paciente $\mathrm{P}$ pode ser resultado de uma ativação deficiente da via UPR. Estabelecemos um sistema que nos permite investigar como o stress de ER altera o ciclo celular e vice-versa. A identificação dos mecanismos correguladores que existem entre UPR e componentes do ciclo celular proverá entendimento dos mecanismos que coordenam a resposta de um linfócitos B depois da ativação antigênica

Palavras-chave: UPR. Linfócitos B. CVID. Ciclo celular. 


\begin{abstract}
Pinto BP. Effect of the deregulation of the UPR pathway in the expression of cyclin A1 in human B lymphocytes. [Masters Thesis (Immunology)]. São Paulo: Instituto de Ciências Biomédicas, Universidade de São Paulo; 2012.

The unfolded protein response (UPR) is a signaling pathway activated by endoplasmic reticulum (ER) stress. Unfolded proteins are sensed by three ER residents, IRE1 $\alpha$, PERK and ATF6. Previously we described a patient (Patient P) with Common Variable Immunodeficiency (CVID) whose delayed activation of the UPR correlates with accumulation of immunoglobulins inside the ER. Epstein Barr virus (EBV)-immortalized B cells (EBV-B) from this and some other CVID patients have a slower rate of proliferation when compared to EBV-B cells from healthy donors. Cyclin A1 is a protein involved in cell cycle regulation and has its expression increased significantly when induced by IRE1a, suggesting an intersection between cell cycle and ER stress.Our main goal is to clarify the deficient proliferation of B lymphocytes from CVID patients, investigating whether ER stress can alter the ability of a B cell to cycle.To investigate the modulation of the UPR through the cell cycle, we established a system where a combination of ER stressors are used to activate the UPR pathway followed by the analysis of the cell cycle, apoptosis and expression of UPR targets in several lineages of B cells as well as ex vivo B cells. Cells from each sample were analyzed by flow cytometry (proliferation, cell cycle and apoptosis), real time PCR and RTPCR.Our results showed that chronic UPR stress interrupted cell cycling of EBV-B cells through dysruption of the cyclic nature of cyclin A1. Upon chronic ER stress, the expression of cyclin A1 remained high even after 24 hours of culture. As a consequence we observed increased numbers of cells at S and G1 phases, depend of the cell type and drug. Furthermore, chronic ER stress triggered early apoptosis through activation of the PERK branch of the UPR and increased levels of CHOP transcripts, a pro apoptotic factor downstream of PERK. EBV$\mathrm{B}$ and ex vivo cells from patient $\mathrm{P}$ were also analyzed and presented low metabolic rate and a high apoptosis rate even in the absence of ER stressors. We were unable to observe cell cycle alterations in this patient's cells due to their lack of proliferative response to several tested stimuli. However we noted that the deficiency of UPR pathway activation by Patient $P$ appears to be on the recognition of unfolded proteins. Patient's P lymphocytes outline a response when the ER stress is generated by drugs such as thapsigargin and brefeldin A, but not with DTT.Our results support the hypothesis that deficient proliferation observed in some CVID patients might be the result of deficient UPR activationWe established a system that allows us to investigate how ER stress interferes with cell cycling and vice-versa. The identification of the co-regulatory mechanisms existing between UPR and cell cycling components will provide us with insights in the mechanisms that coordinate a B cell's response after antigenic activation
\end{abstract}

Keywords: UPR. B cells. CVID. Cell cycle. 


\section{LISTA DE FIGURAS}

Figura 1 - Via de sinalização em resposta à proteínas desdobradas no retículo endoplasmático (via Unfolded Protein Response - UPR).

Figura 2 - Expansão do ER durante a diferenciação dos linfócitos B em plasmócitos

Figura 3 - Cinética de proliferação das células imortalizadas do controle e do Paciente P.

Figura 4 - Esquema da atividade dos complexos ciclinas e cdks durante a progressão do ciclo celular.

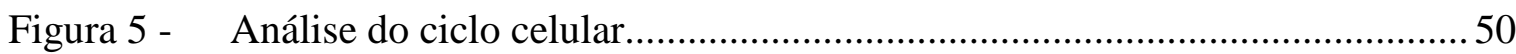

Figura 6 - Análise do ciclo celular na titulação do estresse do ER causado por DTT....... 54

Figura 7 - Expressão relativa dos genes BiP, CHOP e ciclina A1 após a indução da via UPR com DTT.

Figura 8 - A transcrição de $\mathrm{BiP}$ após a indução do estresse com $5 \mathrm{mM}$ de DTT é maior na condição crônica.

Figura 9 - A transcrição de CHOP após a indução do estresse com 5 mM de DTT é maior na condição crônica e está relacionada com o aumento da morte celular.

Figura 10 - As células dos Controles saudáveis são mais sensíveis à morte celular induzida por $\mathrm{CHOP}$

Figura 11 - Distúrbio na transcrição de Ciclina A1 após a indução do estresse com 5 mM de DTT agudo e crônico.

Figura 12 - O estresse do ER provocado pelo tratamento com DTT causa a parada do ciclo celular em G1 na condição aguda e em S e G2 na condição crônica.....

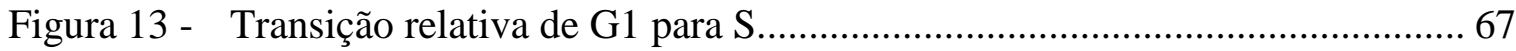

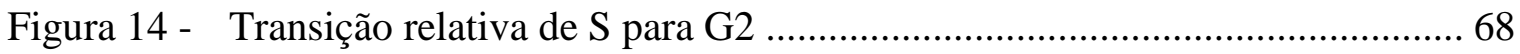

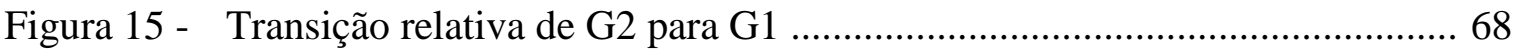

Figura 16 - Parada das células na fase G1 do ciclo celular após o estresse do ER provocado pela incubação com tapsigargina por $24 \mathrm{~h}$

Figura 17- Parada das células após a indução da via UPR é dependente da droga utilizada como estressor. 
Figura 18 - Atraso da proliferação celular provocado pelo estresse induzido pelo tratamento com DTT e nocodazol................................................................. 75

Figura 19 - Parada do ciclo celular em S após o estresse crônico com DTT e em G2 após o tratamento com nocodazol.............................................................. 76

Figura 20 - A parada das células em G2 provocada pelo nocodazol não ativou a via UPR.

Figura 21- Atividade metabólica do linfócitos B imortalizados do Paciente $\mathrm{P}$ e de um Controle saudável.

Figura 22 - O DTT agudo não induz ativação da via UPR no Paciente P....................... 80

Figura 23 - Ativação deficiente da via UPR no Paciente P.......................................... 80

Figura 24 - Expressão relativa dos genes BiP, CHOP, EDEM e GRP94 da coleta 3 no Paciente $\mathrm{P}$

Figura 25 - A resposta deficiente do Paciente P frente ao estresse causado pelo DTT não é decorrente de um dano estrutural.....

Figura A.1 - Análise do ciclo celular por citometria de fluxo utilizando PI e fixação por etanol.

Figura C.1 - Quantificação do splicing do XBP1 após a indução do estresse por DTT no Controle saudável.

Figura C.2 - Análise do ciclo celular após o tratamento agudo com 5 mM de DTT 100

Figura C.3 - Análise do ciclo celular após o tratamento crônico com 5 mM de DTT.......100

Figura D.1 - Tentativa de sincronização dos linfócitos EBV com meio privado de ${ }_{101}$ SFB. 


\section{LISTA DE TABELAS}

Tabela 1 - Concentração ótima dos oligonucleotídeos para cada gene............................ 48

Tabela 2 - Valores de eficiência da reação para cada gene. 49

Tabela 3 - Porcentagem de células nas fases do ciclo celular após o tratamento com DTT

Tabela 4 - Porcentagem de células mortas após o tratamento com DTT.

Tabela 5 - Acúmulo de células do Controle 1 e tumoral 1 e 2 após a indução da UPR com DTT $5 \mathrm{mM}$

Tabela 6 - Porcentagem de células apoptóticas e necróticas............................................ 79

Tabela B.1 - Porcentagem de células mortas após a incubação com DTT.........................97

Tabela C.1 - Porcentagem de células mortas no Controle 1..............................................98

Tabela C.2 - Porcentagem de células mortas no Controle 2 2......................................... 98

Tabela C.3 - Porcentagem de células mortas no Tumoral 1 1............................................. 99

Tabela C.4 - Porcentagem de células mortas no Tumoral 2 …........................................ 99

Tabela D.1. - Porcentagem de células em cada fase do ciclo celular................................. 101

Tabela D.2 - Tentativa de sincronização dos linfócitos EBV-B com meio privado de

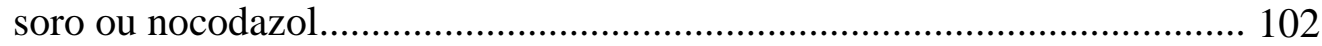




\section{LISTA DE QUADROS}

Quadro 1 - Células imortalizadas por EBV e linhagens tumorais. 40

Quadro 2 - Níveis séricos de anticorpos no soro do Paciente $\mathrm{P}$ na época do diagnóstico

Quadro 3 - Programa de ciclagem PCR semi quantitativo.

Quadro 4 - Sequência dos oligonucleotídeos iniciadores utilizados na reação de PCR semi quantitativo.

Quadro 5 - Sequência dos oligonucleotídeos iniciadores utilizados na reação de qPCR........

Quadro 6 - Representação esquemática das condições de tratamento de estresse agudo e crônico. 


\section{LISTA DE ABREVIATURAS}

APRIL - do inglês A proliferation-inducing ligand

ATP - do inglês adenosine triphosphate

BAFF - do inglês B cell-activating factor

BAFFR - receptor da molécula BAFF

BCL-6 - do inglês B cell leukemia/lymphoma-6

BCR - do inglês B cell receptor (receptor de linfócito B)

$\mathrm{BiP}-$ do inglês binding protein

BLIMP-1 - do inglês B lymphocyte inducer of maturation program 1

bZIP - do inglês basic leucin-zipper

cAMP - do inglês cyclic adenosine monophosphate

$\mathrm{CD}$ - do inglês cluster of differentiation

cDNA - DNA complementar

$\mathrm{C} / \mathrm{EBP}$ - do inglês CCAAT enhancer binding protein

$\mathrm{CG}$ - centro germinativo

$\mathrm{CHOP}$ - do ingles C/EBP-homologous protein

CREB - do inglês cAMP response-element-binding

CVID - do inglês Common Variable Immunodeficiency (imunodeficiência comum variável)

DTT - Dithiothreitol

EBV - do inglês Epstein Barr vírus (vírus Epstein Barr)

EBV-B - linfócitos B imortalizados com EBV

eIF $2 \alpha$ - do inglês eucaryotic translation initiation factor 2, a $\square$ subunit (subunidade alfa do fator de iniciação da tradução 2)

ER - Retículo Endoplasmático

ERAD - do inglês ER-associated degradation (degradação associada ao ER)

ERSE - do inglês ER stress element response (elemento responsivo ao estresse do ER)

GADD34 - do inglês growth arrest and DNA damage-inducible gene 34

GRP - do inglês glucose-regulated protein

IRE1 - do inglês inositol-requiring enzyme 1

JNK - do inglês Jannus Kinase

LPS - lipopolissacarídeo

$\mathrm{NK}$ - do inglês natural killer

ORF - do inglês open reading frame (fase de leitura aberta)

PBMC - do inglês peripheral blood mononuclear cell (célula mononuclear de sangue periférico)

PERK - do inglês PKR-like ER kinase 
PP1 - proteína fosfatase 1

RNAm - RNA mensageiro

TACI - do inglês transmembrane activator and calcium-modulator and cyclophilin ligand interactor

$\mathrm{TNF}$ - do inglês tumor necrosis factor (fator de necrose tumoral)

TRAF2 - do inglês TNF receptor-associated factor 2

UPR - do inglês Unfolded Protein Response

UPRE - do inglês unfolded protein response element (elemento responsivo a proteínas não dobradas)

XBP-1 - do inglês X-box binding protein 1 
1 INTRODUÇÃ

1.1 O Retículo endoplasmático e o dobramento de proteínas ........................................... 23

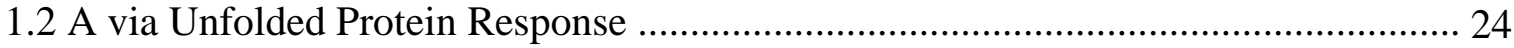

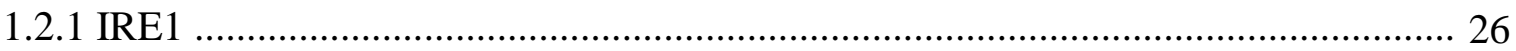

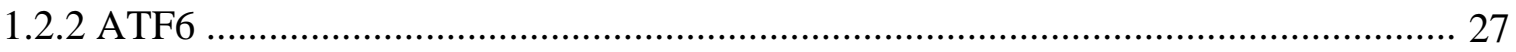

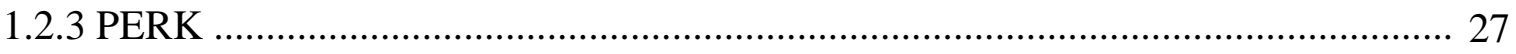

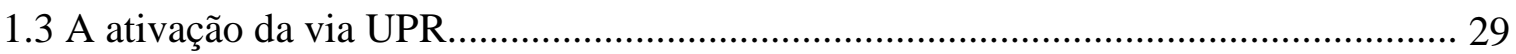

1.4 O papel da via UPR na diferenciação dos plasmócitos ............................................ 30

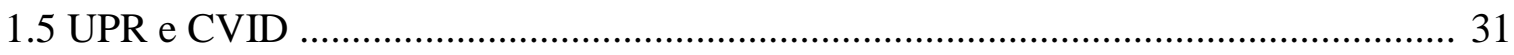

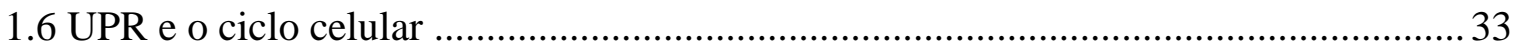

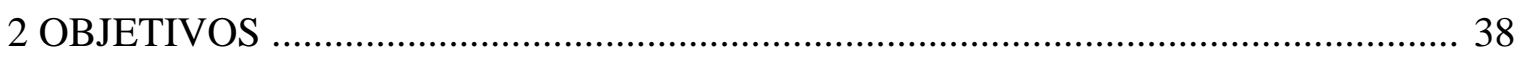

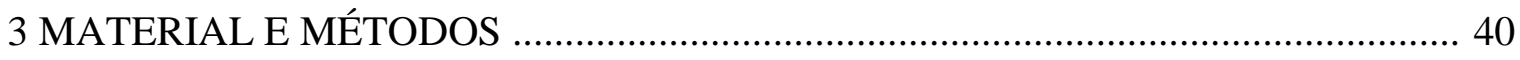

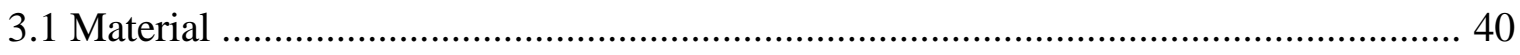

3.1.1 Imortalização dos linfócitos B......................................... 41

3.1.2 Cultivo de células imortalizadas por EBV ……............................................... 41

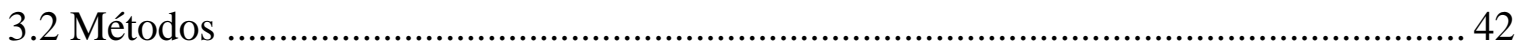

3.2.1 Separação de linfócitos B ex-vivo por RosetteSep ................................................ 42

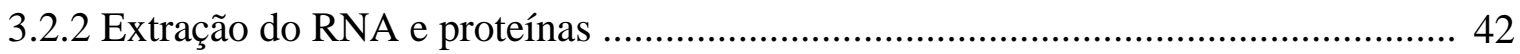

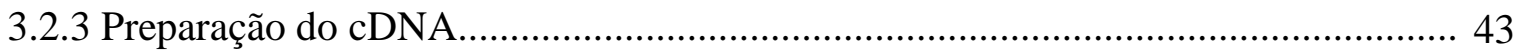

3.2.4 Reação em cadeia da polimerase (PCR) semi quantitativo .................................... 43

3.2.5 Fracionamento dos fragmentos amplificados em gel de agarose .......................... 44

3.2.6 Reação em cadeia da polimerase (PCR) em tempo real (q PCR) ........................... 44

3.2.7 Ensaio de ciclo celular com Iodeto de Propídio .................................................... 46

3.2.8 Ensaio de apoptose e necrose com AnexinaV-FITC e Iodeto de Propídio............... 46

3.2.9 Proliferação celular com CFSE (5(6)-Carboxyfluorescein N-hydroxysuccinimidyl ester. 
3.2.10 Ensaio de viabilidade por MTT (3-(4-Dimethylthiazol-2yl)2,5

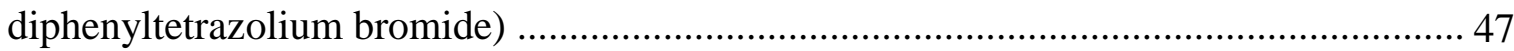

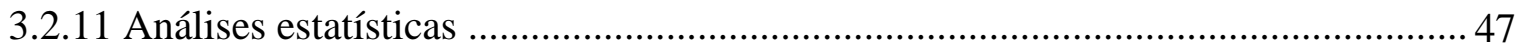

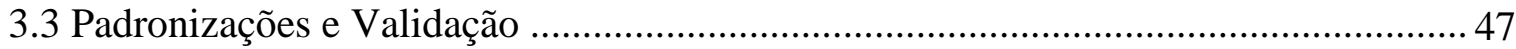

3.3.1 Padronização da técnica de Reação em Cadeia da Polimerase em tempo real (qPCR)

3.3.2 Padronização da análise do Ciclo Celular 49

4 RESULTADOS E DISCUSSÃO

4.1. Titulação do DTT com estressor do ER.

4.1.1 A dose de $5 \mathrm{mM}$ crônico provocou a parada do ciclo em $\mathrm{S}$ 53

4.1.2 A dose de 5mM de DTT ativou a via UPR além de provocar um aumento na morte celular

4.2 Avaliação e comparação do estresse agudo e crônico induzido por DTT em linfócitos B imortalizados de indivíduos saudáveis e linhagens tumorais 56

4.2.1 O estresse crônico com $5 \mathrm{mM}$ de DTT provocou maior ativação da UPR.

4.2.2 A transcrição de CHOP está correlacionada com o aumento da morte celular nas células dos controles

4.2.3 A ativação da via UPR e a transcrição de Ciclina A1 estão relacionadas com a parada do ciclo celular

4.3 Ativação da via UPR e estudo do ciclo celular com outras drogas estressoras de ER.71

4.3.1 A tapsigargina induz a parada do ciclo celular em G1 71

4.4 Avaliação e comparação do estresse agudo e crônico induzido por DTT na proliferação celular

4.4.1 A incubação com $5 \mathrm{mM}$ de DTT induz um atraso na proliferação tanto nos controles quanto nas Tumorais

4.4.2 A interrupção do ciclo celular não é capaz de ativar a via UPR. 76

4.5 Análise da ativação da via UPR e ciclo celular em linfócitos B do Paciente P. 77

4.5.1 Os linfócitos $\mathrm{B}$ imortalizados do Paciente $\mathrm{P}$ apresentam baixa atividade metabólica 
4.5.2 Os linfócitos $\mathrm{B}$ do Paciente $\mathrm{P}$ não ativam a UPR em resposta ao estresse com DTT

4.5.3 A ausência da ativação da UPR pelo Paciente P após a incubação com DTT não é

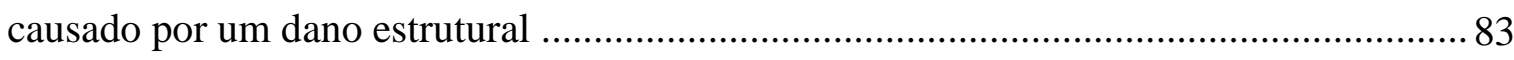

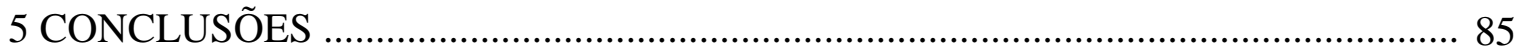

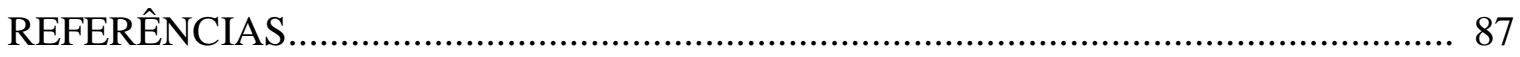

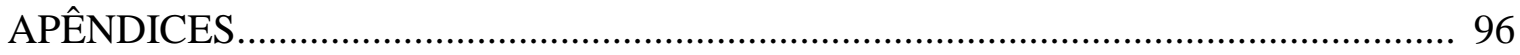

APÊNDICE A - Padronização da análise do ciclo celular................................................ 96

APÊNDICE B - Titulação do estresse com DTT............................................................ 97

APÊNDICE C - Comparação do estresse agudo e crônico com 5 mM de DTT................ 98

APÊNDICE D - Sincronização das células controles...................................................... 101 
1 INTRODUÇÃO 
1.1 O retículo endoplasmático e o dobramento de proteínas

O retículo endoplasmático (ER) é uma organela exclusiva de células eucarióticas, formado por uma invaginação da membrana plasmática e constituído por um extenso labirinto de ramificações tubulares achatadas (1).

O ER é uma organela chave para a secreção de proteínas, tendo um papel importante em passos que incluem o dobramento, as modificações pós-traducionais e a formação de complexos protéicos. Aproximadamente um terço de todas as proteínas celulares é translocado para dentro do lúmen do ER e este deve assegurar que as proteínas sejam dobradas corretamente (1).

O dobramento de uma proteína começa assim que sua síntese se inicia, nos ribossomos citosólicos, e só é considerado encerrado quando esta proteína sai do ER (1-3). No caso do ER de mamíferos, o dobramento das proteínas é facilitado por dois sistemas de chaperonas residentes nessa organela: calnexina/calretirulina e BiP (Binding Protein, HSPA5 - heat shock $70 \mathrm{kDa}$ protein 5 ou GRP78 - glucose responsive protein), que se associam com as cadeias polipeptídicas assim que estas emergem no lúmen do ER. A BiP é responsável pela detecção de regiões desdobradas de peptídeos nascentes, sendo o principal sistema de dobramento de proteínas não glicosiladas ou naquelas em que a glicosilação ocorre tardiamente (4). A glicosilação das cadeias polipeptídicas nascentes também aumenta a sua solubilidade e diminui sua agregação (5).

A fim de que apenas proteínas dobradas corretamente possam sair e atingir o seu destino final, o ER possui mecanismos de controle de qualidade dos diferentes estágios de dobramento. Este controle de qualidade, que identifica proteínas mal ou não dobradas e as redireciona para a degradação via ubiquitina/proteassoma é denominado de ERAD (ERassociated protein degradation) (6). Proteínas que apresentam uma mutação ou um domínio estrutural que impede seu dobramento correto, mesmo com a ajuda de chaperonas, devem ser impedidas de entrar na via secretória e se acumulam no ER. Quando proteínas que são exportadas do ER sem o dobramento correto associam-se a algumas doenças humanas como diabetes do tipo I e fibrose cística (6). Além disso, a precipitação de proteínas em formas maldobradas pode levar a morte celular por apoptose. Várias doenças estão associadas a este fenômeno, como por exemplo: Doença de Huntington (7), Mal de Alzheimer (8) e a fibrose cística (9).

O ER deve aumentar a sua capacidade de dobramento de proteínas em células que se encontram em um estágio específico e em tecidos com altos níveis de proteínas secretadas. Os 
linfócitos B ativados, que secretam grandes quantidades de anticorpos, e as células $\beta$ pancreáticas, produtoras de insulina, são alguns exemplos de células que requerem um aumento da capacidade de dobramento de proteínas do ER (10).

O acúmulo de proteínas não dobradas e/ou mal dobradas resulta no estresse do ER. Para resolver estes acúmulos transitórios, o ER pode aumentar sua capacidade de dobrar proteínas e/ou aumentar sua capacidade de destruí-las. Nas células eucarióticas um dos mecanismos que medeia essa regulação na tentativa de resolver o estresse do ER é a via Unfolded Protein Response (UPR). A UPR induz a transcrição de chaperonas do retículo endoplasmático para aumentar o dobramento de proteínas, e atenua a tradução de proteínas para diminuir a sobrecarga do ER. A via UPR também regula a transcrição de genes associados ao ERAD, o que aumenta a degradação protéica, processo no qual proteínas mal dobradas são exportadas para o citosol e degradadas pelo sistema ubiquitina/proteassoma. A via UPR ainda ativa o programa de apoptose se todas essas medidas anteriores falharem (11, 12).

\subsection{A via Unfolded Protein Response}

A Unfolded Protein Response (UPR) é uma complexa via de sinalização que é ativada em todos os organismos eucarióticos em resposta a perturbações no ambiente do ER que possam interferir no dobramento correto de proteínas. A via UPR foi originalmente descrita na levedura Saccharomyces cerevisae e é altamente conservada evolutivamente, e está presente desde fungos a mamíferos $(13,14)$.

Análises da via UPR iniciaram-se no fim dos anos 80, quando foi verificado que o acúmulo de proteínas não dobradas no retículo endoplasmático induzia a expressão das chaperonas GRP78 e GRP94 (15). O uso da levedura Saccharomyces cerevisae como modelo de estudo da via UPR levou a uma rápida compreensão dos mecanismos moleculares desta via.

O estresse do retículo endoplasmático pode ser causado por várias condições fisiológicas e patológicas que alteram sua homeostasia, tais como um desbalanço de cálcio (16), níveis diminuídos de glicose (17), isquemia tecidual (18), infecções virais (19), mutações que alteram proteínas (20) e a diferenciação terminal de linfócitos B em plasmócitos (21).

Durante a ativação da via UPR em vertebrados, a presença de estresse é detectada por três proteínas transmembranares do ER: PERK (PKR-like ER kinase), ATF6 (Activating 
transcription factor 6) e IRE1 (Inositol-requiring enzyme1) (22, 23). Essas proteínas associam-se pelos seus domínios luminais com a chaperona BiP, e quando liberadas, cada proteína inicia um mecanismo regulatório diferente (Figura 1).

Figura 1 - Via de sinalização em resposta às proteínas desdobradas no retículo endoplasmático (via Unfolded Protein Response - UPR)

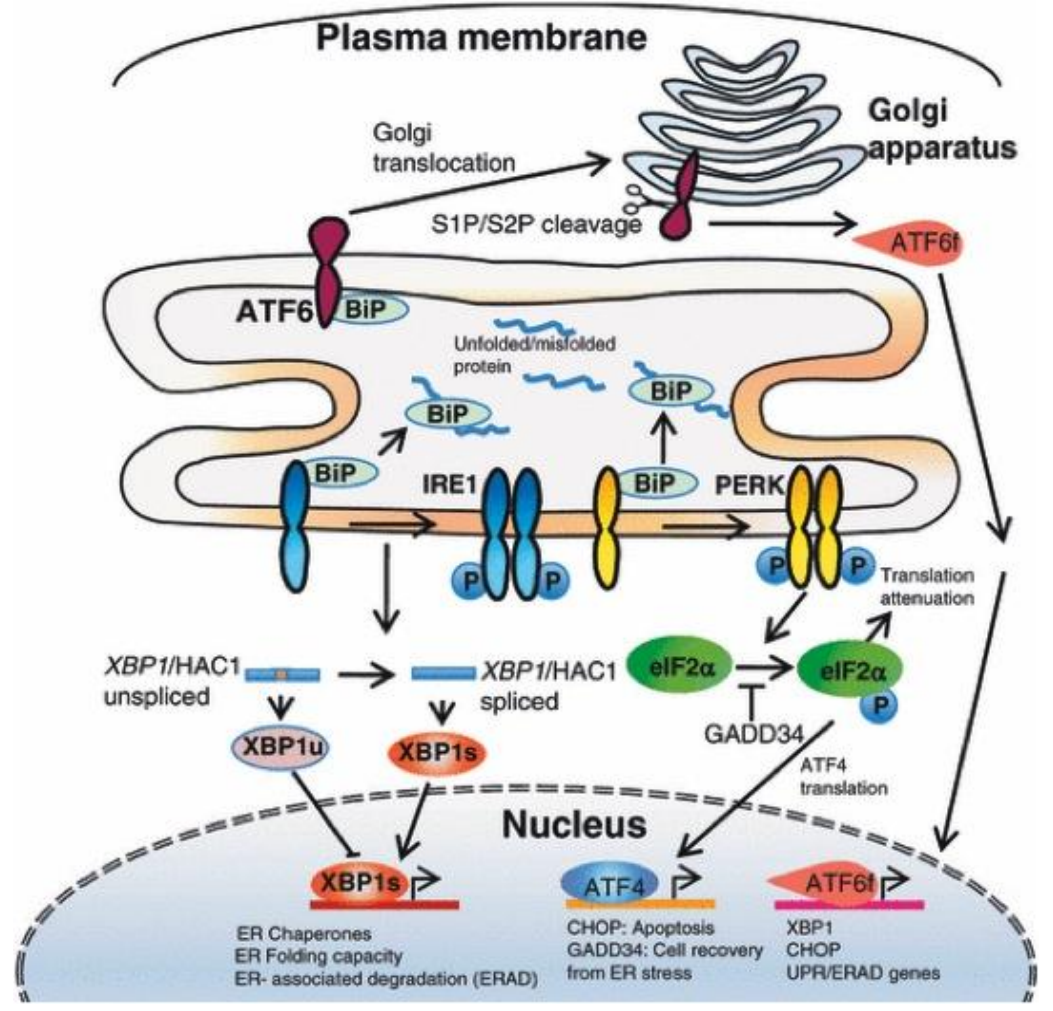

As proteínas transmembranares IRE1, PERK e ATF6 após se desligarem da BiP são ativadas e induzem a transcrição de genes responsáveis pelo aumento da produção de chaperonas, diminuição da carga de proteínas e pela melhora na capacidade de degradação associada ao retículo (ERAD). O estresse do ER desencadeia a via UPR com o objetivo de aumentar a eliminação de proteínas mal dobradas e consequentemente diminuir o estresse do ER.

Fonte: Adaptado de Costa et al., 2011 (24)

A BiP é uma das chaperonas mais importantes do ER e auxilia o dobramento de proteínas nascentes assim que estas entram no ER pelo canais protéicos Sec 61. Durante a ativação da via UPR, a BiP se dissocia das proteínas transmembranares IRE1, ATF6 e PERK pois possui maior afinidade por proteínas não dobradas que se encontram no lúmen do ER (25). Essa dissociação permite que tanto a IRE1 quanto a PERK se dimerizem e tornem-se ativadas $(23,26)$. A dissociação da BiP com o ATF6 permite que este migre para o complexo de Golgi (27). 
A BiP desliga-se facilmente dos sensores transmembranares, mesmo quando existem baixas concentrações de proteínas não dobradas (26). Entretanto não é sabido o mecanismo que garante que a BiP fique ligada aos sensores na ausência de estresse. O desligamento da BiP das proteínas transmembranares IRE1, PERK e ATF6 poderia por si só ativar a via UPR, idenpendentemente de outros sinais. Entretanto esse não é o caso para a ativação do ATF6. Um sinal desconhecido também é necessário para o transporte do ATF6 do ER para o Golgi (27).

\subsubsection{IRE1}

A IRE1 é uma kinase serina/treonina transmembranar do tipo I cujo domínio Nterminal se localiza no lúmen do ER e a porção C-terminal se estende pelo citoplasma (28). Existem dois homólogos do gene ire1 em mamíferos: ire1 $\alpha$, que é expresso na maioria das células e tecidos, e ire1 $\beta$, cuja expressão está primariamente restrita às células epiteliais intestinais (29).

A porção citosólica da IRE1 contém tanto um domínio kinase quanto um endoribonuclease, ambos são requeridos para o splicing não convencional do RNA mensageiro (mRNA) do XBP1. O XBP1 é um membro da família CREB/ATF de fatores de transcrição, originalmente identificado como importante para a diferenciação dos linfócitos B em plasmócitos (21).

O domínio endoribonuclease da IRE1 promove uma clivagem sítio específico no mRNA do XBP1, que remove um íntron de 26 nucleotídeos. A remoção deste íntron produz uma mudança de fase de leitura do mRNA do XBP1, resultando numa proteína de 376 aminoácidos que atua como a forma ativa do fator de transcrição XBP1 (XBP1spliced XBP1s) (30). A forma unspliced do mRNA (XBP1u) atua como dominante-negativo do fator de transcrição. No núcleo, o XBP-1s se liga ao ERSE (ER stress responsive element), induzindo a transcrição de chaperonas, e ao UPRE (unfolded protein responsive element), induzindo a transcrição de genes relacionados à degradação protéica, incluindo o EDEM (ER degradation enhancing a-mannosidade-like protein) (31). O EDEM é uma proteína transmembranar tipo II do ER. Sua superexpressão aumenta a degradação de glicoproteínas mal dobradas que contenham um motivo oligossacarídeo específico, o Man8-(GluNAcMannooctaose-di-(N-acetyl-D-glucosamine) (32).

A IRE1 também tem um papel importante na regulação da apoptose dependente da ativação da via UPR. Seu domínio citoplasmático pode recrutar a proteína adaptadora TRAF2 
(TNF receptor-associated factor 2), que por sua vez recruta e ativa a caspase-12, um indutor de morte específico para o estresse do ER (33). Durante a ativação da via UPR, TRAF2 se dissocia da IRE1, levando à ativação da JNK kinase (JNKK), que ativa JNK. A ativação de JNK resulta na ativação do fator de transcrição API (activing protein-1), que está envolvido com a morfogênese embrionária, a proliferação e a apoptose (34).

A função da IRE, durante a ativação da via UPR, envolve desde a regulação da expressão de genes relacionados à degradação protéica e a chaperonas, quanto na regulação da apoptose.

\subsubsection{ATF6}

O ATF6 é outro membro da família CREB/ATF de fatores de transcrição (24). Mediante a ativação da UPR, a interação do ATF6 com a BiP é quebrada, e o ATF6 migra para o complexo de Golgi, onde sofre clivagem proteolítica pelas proteases S1P e S2P (site-1 e site-2 proteases), liberando seu fragmento N-terminal, chamado de ATF6f, que então se transloca para o núcleo (35).

No núcleo, o ATF6f ativa o ERSE (ER stress response element), que controla a expressão de genes que codificam para chaperonas residentes do ER como a BiP e GRP94 (33). Além disso, o ATF6 também induz a transcrição de XBP-1 $(27,35)$.

\subsubsection{PERK}

O braço sinalizado pela proteína PERK é aquele que possui funções mais diversificadas dentro da via UPR, incluindo a repressão da tradução e a ativação de um fator de transcrição, o ATF4 $(37,38)$. A PERK também está envolvida tanto na via de sinalização pró-apoptótica quanto na de sobrevivência, sendo importante para decidir o destino das células (39). E, finalmente, a PERK está envolvida com a parada das células do ciclo celular durante o estresse do ER (40).

Assim como a IRE1, a PERK é uma kinase serina/treonina transmembranar do tipo I e possui a sua cauda N-terminal no lúmen do ER (16). Quando ativada, a PERK fosforila a subunidade alfa do fator de iniciação translacional-2 (eIF2 $\alpha$ ). A fosforilação do eIF2 $\alpha$ mantém esse fator na forma inativa e interfere na formação do complexo iniciador da tradução 43S, levando à repressão da tradução (16). Esta inibição da tradução reduz o influxo de proteínas recém sintetizadas no ER (16). 
O ATF4 é um fator de transcrição que pertence à família CREB de fatores de transcrição, e pode induzir a transcrição de CHOP/GADD153 (C/EBP homologous protein) e GADD34 (growth-arrest DNA-damage gene 34) (16). O GADD34 é uma proteína citosólica que se associa com a proteína fosfatase 1 (PP1), que por sua vez desfosforila o eIF2 $\alpha$ e promove a retomada da síntese protéica, um mecanismo de retroalimentação que assegura que a via não seja hiperativada (42). Em fibroblastos murinos deficientes em PERK, a transcrição de CHOP durante a ativação da via UPR encontra-se diminuída, demonstrando que a CHOP é um alvo dependente da ativação da PERK (37).

Dados experimentais correlacionam a transcrição de CHOP com a apoptose. A superexpressão de CHOP aumenta a apoptose, enquanto que células deficientes de CHOP têm a morte reduzida (43). A CHOP pode induzir a expressão do DR5 (death receptor 5) e do TRB3 (tribbles-related protein 3) de forma estresse-dependente e modular a morte celular associada a UPR (44). O DR5 é um membro da família TNFR e pode mediar a morte celular através do complexo FADD de sinalização (44).

A CHOP também sensibiliza as células à morte induzida por estresse através da supressão do fator antiapoptótico B cell lymphoma-2 (Bcl-2) e a superexpressão de Bim, o único fator pro-apoptótico da família Bcl-2 (45). Além disso, a CHOP pode induzir a apoptose por meio da superexpressão de Ero-1, uma tiol-oxidase que medeia a formação de pontes dissulfeto para promover o dobramento de proteínas no ER, mas também gera como subproduto espécies reativas de oxigênio (ROS) que podem contribuir para a ativação de uma gama de vias pro-apoptóticas (45).

A PERK tem um papel na ativação de genes apoptóticos, sendo também responsável pela clivagem proteolítica e ativação da procaspase-12, uma caspase associada ao ER (33). É sabido que a caspase-12 não é ativada em MEF (murine embryonic fibroblast) $\mathrm{PERK}^{\top} /$ (39). Além disso, células $\mathrm{PERK}^{\top}{ }^{\top}$ são mais susceptíveis à morte celular durante a ativação da via UPR (39). Essas observações sugerem que a ativação da PERK leva a eventos que protejem a célula da morte enquanto induz, ao mesmo tempo, alguns eventos apoptóticos. Ou seja, a PERK medeia eventos promovendo a sobrevivência e a morte celular simultaneamente, sem se comprometer especificamente com nenhuma das vias (46-48). 
1.3 A ativação da via UPR

A ativação dos três sensores da UPR, IRE1, ATF6 e PERK, leva a uma reprogramação transcricional pela indução de três fatores de transcrição: XBP1, ATF6f e ATF4. Cada um desses fatores de transcrição é ativado por um mecanismo exclusivo: o XBP1 é produzido pela IRE1 via o splicing do mRNA do XBP1; ATF6f é ativado por uma clivagem proteolítica do seu precursor o ATF6; e a tradução do ATF4 é aumentada devido a sua associação preferencial com poliribossomos durante a ativação do braço PERK da UPR $(4,6)$.

O perfil genômico de fibroblastos derivados de embriões de camundongos deficientes para XBP1 ou ATF4, ou tecido deficiente de ATF6f, revelou que, cada fator de transcrição é responsável por uma parcela de genes alvos da UPR (37, 49-52). Por exemplo, a transcrição de EDEM, DnaJ/Hsp40, p58 ${ }^{\mathrm{PK}}$, ErdJ4, HEDJ, PDI-P5, PAMP4 é regulada por XBP1 (52). A indução transcricional desses genes após a ativação da UPR em células deficientes de XBP1 é reduzida (52). Muitas proteínas codificadas por esses genes estão envolvidas no ERAD, como por exemplo o EDEM (32). O EDEM codifica para a proteína ER degradation enhancing alfamannosidade like, envolvida no reconhecimento de substratos alvos para a degradação. Sendo assim, um papel importante do braço IRE1-XBP1 durante a ativação da UPR é a degradação de proteínas permanentemente não dobradas, via $\operatorname{ERAD}(11,12,37)$.

Por sua vez o ATF6f é capaz de induzir a transcrição de XBP1 e está possivelmente envolvido com a regulação positiva da chaperona BiP, uma vez que induz a transcrição dessa chaperona $(27,53)$.

O braço da PERK-ATF4 pode ser responsável pelo destino das células durante a UPR, uma vez que os genes alvos incluem CHOP, MGP, GADD45 e $\operatorname{HERP}(4,16,45)$.

Os três braços sinalizadores da UPR são responsáveis pela ativação de genes envolvidos em aspectos diferentes da própria via, mostrando a complexidade destes mecanismos regulatórios.

Além desta complexidade já conhecida, dados recentes mostram genes alvos dependentes de múltiplos fatores de transcrição. Células deficientes de SP1 ou SP2, proteases responsáveis pela clivagem do ATF6 no Golgi, exibem uma transcrição diminuída de BiP e GRP98 durante a UPR. Este fato evidencia que a ativação do ATF6 também é necessária para indução do ERSE (ER-response element) durante a UPR, assim como é necessária a do XPB1 $(27,34,49)$. A indução da transcrição de $\mathrm{BiP}$ é também inibida em células $\mathrm{PERK}^{\top} /$, sugerindo que a transcrição de chaperonas do ER como BiP e GRP98 pode também depender do braço PERK-ATF4 (43). 
1.4 O papel da via UPR na diferenciação dos plasmócitos

O papel da via UPR durante a diferenciação de linfócitos B em plasmócitos foi primeiramente observado quando Reimold e colaboradores demonstraram que o fator de transcrição XBP1 é essencial para a diferenciação terminal dos linfócitos B (21). A diferenciação das células B em plasmócitos envolve a remodelagem da via secretora. O ER sofre um processo de expansão, necessário para acomodar grandes quantidades de moléculas de imunoglobulinas (Igs) recém-sintetizadas e assegurar a maturação e montagem das subunidades monoméricas de Igs em complexos multiméricos (Figura 2). Uma vez que este processo aumenta a quantidade de proteínas a serem dobradas no ER, e o acúmulo de proteínas não dobradas estressa o ER, a ativação da via UPR é requerida durante o desenvolvimento do plasmócito $(21,54)$.

Figura 2 - Expansão do ER durante a diferenciação de linfócitos B em plasmócitos

LB

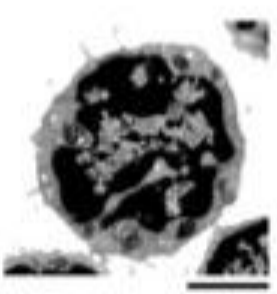

$2 \mu \mathrm{m}$

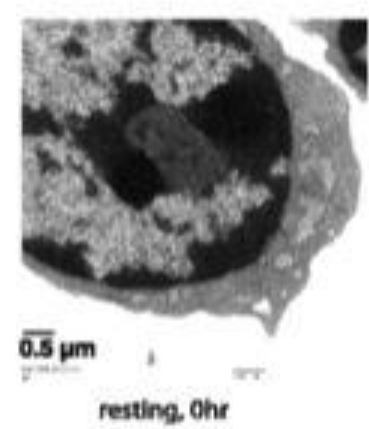

Plasmócito

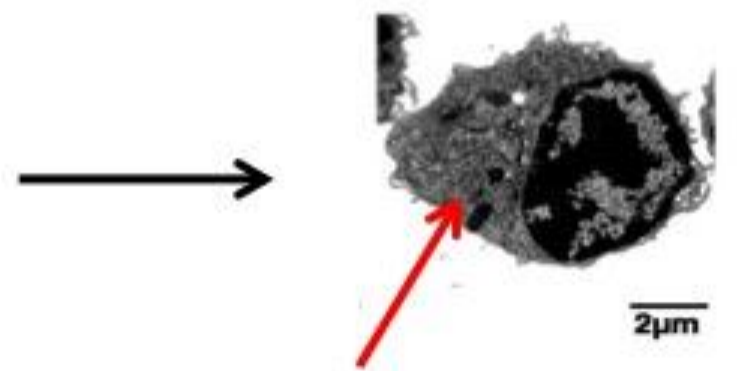

Expansão do RE

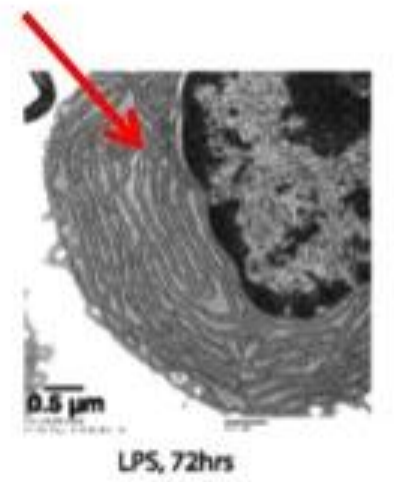

É possível observar a expansão do ER durante o processo de diferenciação de linfócitos B em plasmócitos. Tal evento ocorre para acomodar as imunoglobulinas produzidas e depende da ativação da via UPR.

Fonte: Modificado de Skalet et al. (2005) (55). 
As funções de XBP1 foram inicialmente estudadas em linhagens de mieloma humano, nas quais se verificou um aumento na proliferação de plasmócitos malignos proporcionalmente à expressão de XBP1 induzida por IL-6. A maior expressão de transcritos de XBP1 foi detectada em infiltrados de plasmócitos presentes em doenças inflamatórias, como artrite reumatóide, e em culturas primárias de linfócitos B de camundongos estimuladas com anti-CD40 ou LPS (21). O efeito de XBP1 sobre a biologia dos linfócitos B tornou-se ainda mais evidente após a demonstração de que animais quiméricos deficientes de XBP1 e RAG (XBP1-/- RAG-2-/-) apresentavam defeitos severos na imunidade humoral (21).

Os linfócitos $\mathrm{B}$ dos camundongos quiméricos XBP1\%RAG-2\% mostraram-se menos diferenciados, com expressão aumentada de c-myc e menor expressão da cadeia $\mathrm{J}$ de imunoglobulinas, sendo que esta última é necessária para a geração de plasmócitos secretores de IgM e IgA. No entanto, a reintrodução de XBP1s nas células in vitro induziu proliferação, mudança de classe de imunoglobulinas, expressão de moléculas de superfície e secreção normal de citocinas, demonstrando que o XBP1 é essencial para a formação dos plasmócitos (21).

\subsection{UPR e CVID}

A Imunodeficiência Comum Variável (CVID - common variable immuno deficiency) é a imunodeficiência primária clinicamente importante mais comum em humanos adultos. Estima-se que sua prevalência seja de 1 paciente em 10.000 a 50.000 pessoas (56). O primeiro caso de CVID foi descrito por Janeway e colaboradores em 1953: uma mulher de 39 anos com infecções sinopulmonares recorrentes, bronquite e meningite por Haemophilus influenza (57).

A CVID é definida clinicamente pela presença de três características principais: hipogamaglobulinemia, que é a redução ou ausência nos níveis séricos de dois ou mais isotipos de anticorpos ( $\operatorname{IgG}, \operatorname{IgA}$ ou $\operatorname{IgM}$ ), infecções recidivantes principalmente do trato respiratório e gastrointestinal e a deficiência na resposta humoral, tanto relacionada à infecção natural quanto à vacinação (58).

A produção de imunoglobulinas pelos plasmócitos envolve uma série de eventos e depende da participação de várias vias. Deste modo a hipogamaglobulinemia observada nos pacientes com CVID, pode resultar de falhas desde a apresentação dos antígenos até a secreção das imunoglobulinas.

Nosso grupo identificou anteriormente um paciente com CVID (Paciente P) que 
apresenta a ativação do eixo IRE1 $\alpha / \mathrm{XBP} 1$ atrasada quando comparado com um controle saudável. Dada a importância do XBP1s na ativação da maquinaria secretória de imunoglobulinas por plasmócitos, foi postulado que esse defeito poderia estar relacionado à hipogamaglobulinemia apresentada pelo paciente.

Células B imortalizadas com EBV ou obtidas ex vivo do Paciente P e de um indivíduo saudável foram tratadas com LPS ou Brefeldina A. Foi constatado que o splicing de XBP1 e a transcrição dos genes HSPA5 (codifica para BiP) e IRE1A ocorria de maneira muito mais lenta nas células do Paciente $\mathrm{P}$ após o tratamento do que nas células do controle. Além disso, foi observado nos linfócitos B obtidos do sangue periférico do Paciente P, que a IgM colocalizava com a BiP no interior do retículo endoplasmático, diferentemente do esperado e do observado nas células do controle nas quais a IgM encontrava-se na superfície celular. Essa observação indica a retenção das cadeias de imunoglobulinas no lúmen do ER. $O$ sequenciamento do XBP1 e dos domínios quinase e endonuclease da IRE1 $\alpha$ do Paciente P não mostrou mutações que poderiam explicar a ativação defeituosa. Foi também demonstrado que o tratamento destas células com DMSO, uma chaperona química, foi capaz de resgatar parcialmente a homeostasia do ER nestas células, levando ao desligamento da via UPR e alguma secreção de $\operatorname{IgM}$ e $\operatorname{IgG}(59)$.

Durante a execução desse trabalho, foi observado que as células imortalizadas com EBV do Paciente $\mathrm{P}$ demostravam uma proliferação reduzida em relação às células imortalizadas do controle saudável. Foi realizada uma curva de crescimento na qual as duas culturas foram semeadas com o mesmo número de células e quantificadas na presença de Azul de Trypan (Figura 3).

Figura 3 - Cinética de proliferação das células imortalizadas do controle e do Paciente P

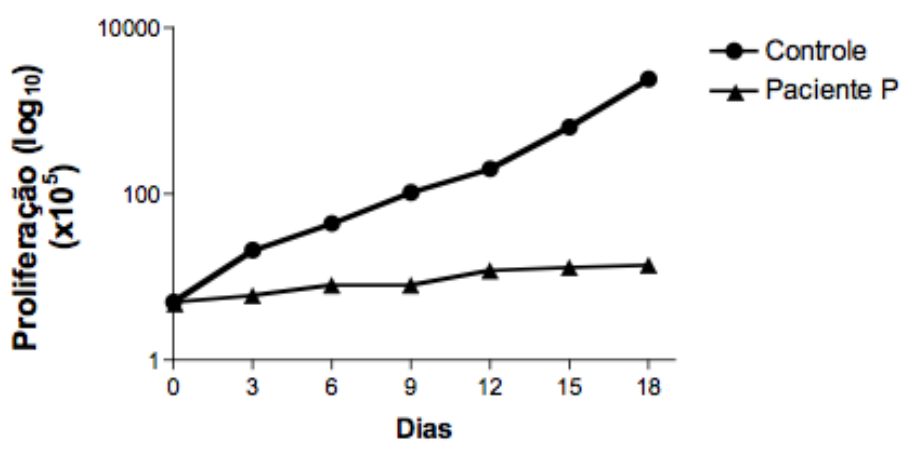

Os linfócitos B imortalizados do Paciente $\mathrm{P}$ possuem uma proliferação reduzida quando comparados com os de um controle saudável. ${ }^{* *} \mathrm{p}=0,02$.

Fonte: Kuribayshi (2006) (60) 
Em acordo com esta observação, Guo e colaboradores também verificaram que as células imortalizadas com EBV de alguns pacientes com CVID possuíam uma taxa de proliferação reduzida quando comparadas com as células imortalizadas por EBV provenientes de indivíduos saudáveis (61).

Ao longo dos anos, alguns estudos têm surgido relacionando a via UPR com o ciclo celular. Em princípio, o estresse do ER poderia indiretamente impedir a progressão do ciclo celular, interferindo na maturação de receptores de fatores de crescimento ou outros moduladores mitóticos/mitogênicos. Além disso, o estresse do ER poderia impedir as células de completar a divisão celular em circunstâncias nas quais o dobramento apropriado de proteínas estivesse prejudicado.

\subsection{UPR e o ciclo celular}

Nas células eucarióticas há uma rede complexa de regulação que governa a progressão do ciclo celular. O ciclo celular é dividido nas fases G1, S (onde ocorre a duplicação do DNA), G2 e M (onde ocorre agregação cromossômica e a divisão celular) (62).

As proteínas kinases cdks (cyclin-depend kinases) fazem parte do sistema de controle do ciclo celular. As ciclinas são proteínas reguladoras das cdks, e têm esse nome pois são sintetizadas e degradadas a cada ciclo celular. A ativação do complexo cdk-ciclina desencadeia os eventos do ciclo celular $(62,63)$

A ativação da cdk4 ou da cdk6 e a ativação da cdk2 são requeridas para a transição G1 para S do ciclo celular e a ativação da kinase cdc2 (cdk1) é necessária para a transição da fase G2 para a M (64). A cdk2 pode se ligar com as ciclinas A ou E, e o cdc2 com as ciclinas A ou B. A atividade kinase do complexo ciclina A-cdk2, cujo pico ocorre em G1-S, é requerida para a entrada na fase $S$ (62). Além disso, a ciclina A também forma um complexo com a cdc2 cujo pico de ativação ocorre na transição de G2 para a mitose. A atividade kinase do complexo cdc2-ciclina A é requerida para a entrada na mitose (65) (Figura 4). 
Figura 4 - Esquema da atividade dos complexos ciclinas - cdks durante a progressão do ciclo celular

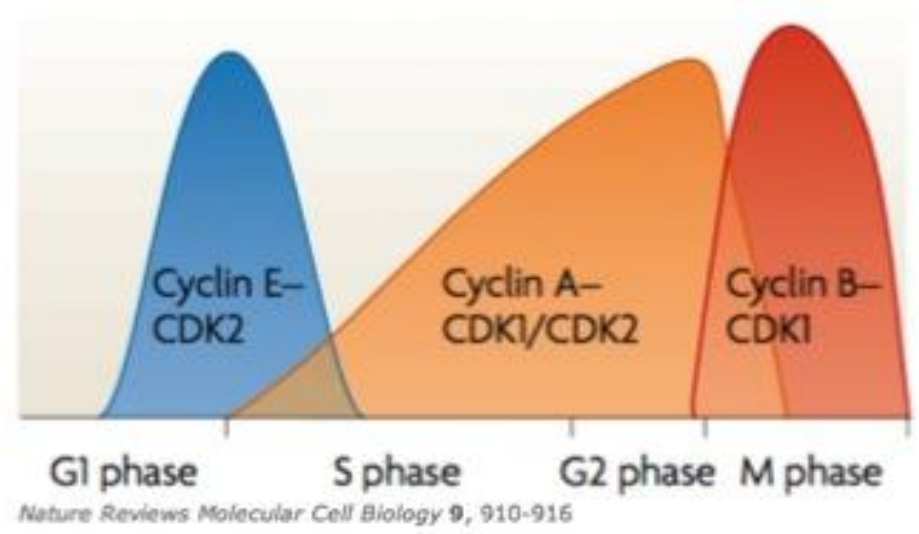

De acordo com o modelo clássico da regulação do ciclo celular, as ciclinas D e as kinases cdk4 e cdk6 regulam os eventos envolvidos com o início da fase G1. O complexo ciclina E-cdk2 inicia a fase S, e os complexos ciclina A-cdk2 e ciclina A-cdk1 regulam o final da fase $\mathrm{S}$. Enquanto o complexo ciclina B -cdk1 é responsável pelo início da mitose.

Fonte: Adaptado de Hochegger et al.(2008) (66)

Alguns autores têm explorado a relação entre o ciclo celular e o estresse do ER. Em 1991, mesmo antes da descrição da ativação da via UPR, Gosh e colaboradores (67) observaram que o tratamento de linhagens celulares musculares de hamster com tapsigargina, um estressor farmacológico do ER, bloqueava o ciclo celular e inibia a síntese de DNA.

A tapsigargina bloqueia a entrada de $\mathrm{Ca}^{+}$no ER aumentando a concentração de cálcio citosólicos e depletando o cálcio de dentro do retículo. A depleção de cálcio provoca o estresse do ER ativando a via UPR (67).

Brewer e colaboradores demonstraram que a tunicamicina induz a perda de ciclina D1 e a parada do ciclo celular em G1 (40). A tunicanicina é outro estressor conhecido do ER que bloqueia a $\mathrm{N}$-glicosilação de proteínas pela inibição de transferência de $\mathrm{N}$-acetilglicosamina fosfato para dolicol fosfato, o primeiro passo na síntese do precursor oligossacarídico (68). A não glicosilação das cadeias polipeptídicas diminui a sua solubilidade e a aumenta sua agregação, o que provoca a ativação da via UPR (5). Nesse estudo, fibroblastos murinos NIH $3 \mathrm{~T} 3$ foram incubados na presença de $0,5 \mathrm{ug} / \mathrm{ml}$ de tunicamicina resultando na parada das células em G0-G1 após 16 h, embora ainda fosse possível observar células nas fases S e G2 do ciclo celular. O tratamento com tunicamicina também foi capaz de induzir o acúmulo das proteínas BiP e CHOP e a diminuição dos níveis de ciclina D1 (69).

Foi demonstrado também que a fosforilação do eIF2 $\alpha$, que dependente da ativação da PERK, leva à inibição da síntese de proteínas em geral e leva à degradação ubiquitina- 
dependente da ciclina D1 pelo proteassoma 26S (70). A ciclina D1 funciona como uma subunidade regulatória de haloenzimas que controlam a progressão através da fase G1 do ciclo celular (71).

Em 2009, outra ciclina foi associada com a ativação da via UPR. Thorpe e colaboradores identificaram a IRE1 $\alpha$ como uma reguladora de proliferação de linhagens celulares derivadas de câncer de próstata humana. Estes autores demonstraram que em circunstâncias onde a atividade da IRE1 $\alpha$ estivesse prejudicada, as células proliferavam vagarosamente, mesmo na ausência de estresse do ER. Em contraste, quando sua atividade estava elevada havia uma estimulação da proliferação celular. Utilizando RNA de interferência para XBP-1 total verificou-se que as células com níveis reduzidos de XBP-1 apresentavam a capacidade de proliferação diminuída. A fim de identificar os genes alvos dependentes de IRE1 $\alpha / \mathrm{XBP} 1$, estes autores compararam a expressão de genes em células controles com células que superexpressavam IRE1 $\alpha$. O gene que codifica para Ciclina A1 teve sua expressão aumentada significativamente, sugerindo sua indução por IRE1 $\alpha$ (72).

A Ciclina A1 humana é altamente expressa em linhagens celulares leucêmicas mielóides, nos testículos e no cérebro, e em baixos níveis em muitas linhagens celulares de diversos tecidos. Tem um importante papel durante a meiose nos testículos, entretanto seu papel durante a mitose ainda não está totalmente esclarecido (73).

Yang e colaboradores encontraram em humanos uma sequência protéica homóloga à Ciclina A1 encontrada em camundongos (84\% de similaridade), que também possui homologia e maior similaridade com a Ciclina A1 encontrada em Xenopus $(59 \%$ de similaridade) do que com a Ciclina A de humanos (48\% de similaridade). Estes autores demonstraram que a Ciclina A1 também é capaz de associar-se a cdk2 e regular a entrada da célula na fase $\mathrm{S}(74)$.

Em contraste, em 2012 Li e colaboradores observaram que em hepatócitos HepG2 a superexpressão da IRE1 $\alpha$ inibe, enquanto o silenciamento por RNA de interferência (siRNA) aumenta, a proliferação celular (75). A superexpressão de IRE1 $\alpha$ inibiu a expressão endógena da kinase PLK1 (Pólo-like kinase 1). A PKL1 pertence à família de kinases serina/treonina com o domínio polo Box, e é importante para assegurar a mitose, uma vez que atua na maturação do centrossomo durante a fase tardia do G2 e no início da prófase no estabelecimento do fuso mitótico $(62,75)$. Portanto níveis reduzidos de PKL1 provocados pela superexpressão de IRE1 $\alpha$, atrasariam a mitose provocando a inibição da proliferação. Após o tratamento com tunicamicina, as células que superexpressavam IRE1 $\alpha$ tiveram o número de células em G1 aumentado e na fase $\mathrm{S}$ diminuídos. Em contraste, as células 
deficientes para IRE1 $\alpha$ tiveram o número de células aumentado na fase $\mathrm{S}$, sugerindo que o nível de ativação da IRE1 $\alpha$ poderia influenciar na fase do ciclo celular que as células acumulam durante o estresse da via UPR (75).

Embora os trabalhos mencionados apresentem mecanismos de ação diferentes quanto à ativação da via UPR sobre o ciclo celular, todos apontam para uma regulação do ciclo dependente da via UPR.

Consideramos que estudar a interação da ativação da via UPR com o ciclo celular possa nos fornecer mais dados sobre os aspectos imunológicos da relação da CVID, UPR o defeito na proliferação dos linfócitos B imortalizados do Paciente P. Além de tentar identificar mecanismos responsáveis pela hipogamaglobulinemia presente no subgrupo de pacientes acometidos pela CVID. 
2 OBJETIVOS 
Neste projeto tivemos como objetivo estudar a relação da ativação via UPR com o ciclo celular. Para isso foram usados linfócitos B de indivíduos saudáveis, células tumorais e linfócitos B do Paciente P.

Consideramos que estudar a interação da ativação da via UPR com o ciclo celular possa nos fornecer mais dados sobre o defeito de proliferação apresentado por um subgrupo de pacientes com CVID, incluindo o Paciente P.

Hipótese 1: O defeito de proliferação observado nos linfócitos $\mathrm{B}$ do Paciente $\mathrm{P}$ está relacionado com a ativação defeituosa da via UPR.

Objetivo 1: Estudar a relação entre a ativação da via UPR e o ciclo celular no Paciente P e em linfócitos B imortalizados por EBV de indivíduos saudáveis, na presença e ausência de estressores do ER.

Hipótese 2: A UPR responde diferencialmente a cada estressor do ER, alterando o ciclo celular de maneira estressor-específica.

Objetivo 2: Estudar a resposta da via UPR frente a estímulos diferentes de estresse do ER nos linfócitos $\mathrm{B}$ do Paciente $\mathrm{P}$ e linfócitos $\mathrm{B}$ imortalizados com EBV de indivíduos saudáveis. 
3 MATERIAL E MÉTODOS 


\subsection{Material}

Este projeto utilizou células $\mathrm{B}$ imortalizadas por EBV do Paciente $\mathrm{P}$ e de indivíduos saudáveis, obtidos anteriormente pelo laboratório (Parecer do Comitê de Ética em pesquisa com Seres Humanos CEPSH 669/ICB-USP e Cadastro de Biorepositório CEPSH.020.11 de 03/03/11). Além disso, foram também coletadas amostras de sangue periférico do Paciente $\mathrm{P}$ e indivíduos saudáveis (CEPSH 973/ICB-USP). Na Tabela 1 caracterizamos as células imortalizadas e linhagens tumorais utilizadas, e na tabela 2 apresentamos os níveis séricos de imunoglobulinas na data do diagnótico do Paciente P.

Quadro 1 - Células imortalizadas por EBV e linhagens tumorais.

\begin{tabular}{|ccccc|}
\hline Indivíduo/Linhagem & Idade & Sexo & Observação \\
\hline Paciente P & 25 & F & CVID - LB imortalizados com EBV \\
L156 (Controle 2) & d & d & Saudável - LB imortalizados com EBV \\
Piedade (Controle 1) & 27 & F & Saudável - LB imortalizados com EBV \\
CSV (Controle 3) & d & M & Saudável - LB imortalizados com EBV \\
CBR (Controle 4) & 25 & F & Saudável - LB imortalizados com EBV \\
RAJI (Tumoral 1) & 11 & M & Tumoral - Linfócitos B de um linfoma de Burkitt \\
TOLEDO (Tumoral 2) & adulto & F & Tumoral - Linfócitos B de um linfoma não Hodgkin \\
\hline
\end{tabular}

$\mathrm{d}=$ desconhecido

Quadro 2 - Níveis séricos de anticorpos no soro do Paciente P na época do diagnóstico

\begin{tabular}{|ccc|}
\hline Anticorpo & Paciente $\mathrm{P}(\mathrm{mg} / \mathrm{dL})$ & Indivíduo Saudável $(\mathrm{mg} / \mathrm{dL})$ \\
IgG & 328 & $770-2000$ \\
IgM & 26 & $25-310$ \\
IgA & 21 & $160-470$ \\
\hline
\end{tabular}


Nesse projeto foram utilizadas linfócitos B imortalizados de 4 indivíduos saudáveis, sendo que as linhagens do Controle 1 e do Controle 2 foram cedidas pelo professor Antonio Condino, já linhagens dos Controles 3 e 4 foram imortalizados pela professora Luiza Guilherme. As linhagens Tumoral 1 e 2 foram cedidas pelo professor Roger Chamas, estas são linfócitos B provenientes de linfomas non-Hodgkins (quadro 1), diferindo apenas pelo fato da linhagem Tumoral 1 ser uma forma incomum e mais agressiva desse linfoma (Burkitt) que comumente afeta crianças. Esse linfoma é caracterizado como agressivo e de crescimento rápido.

\subsubsection{Imortalização dos linfócitos B}

A imortalização dos linfócitos $\mathrm{B}$ foi realizada de acordo com o protocolo já estabelecido (Middleton, 1991) pela equipe da Profa. Dra. Luiza Guilherme Guglielmi, do Laboratório de Imunologia do Instituto do Coração do Hospital das Clínicas da Faculdade de Medicina da Universidade de São Paulo. As células do paciente em estudo e dos indivíduos saudáveis encontram-se armazenadas no Laboratório de Imunorregulação Molecular, onde este projeto foi desenvolvido.

Foram adicionadas $10^{7}$ células mononucleares do sangue periférico em 2,5 ml de meio RPMI-10 (Invitrogen) completo contendo 10\% de SBF, $2 \mathrm{mM}$ de L-glutamina, e 2,5 $\mathrm{ml}$ de sobrenadante com vírus Epstein-Barr (EBV). Incubou-se por 2 horas em banho-maria a $37{ }^{\circ} \mathrm{C}$. Em seguida, $5 \mathrm{ml}$ de RPMI-10 (Invitrogen) contendo 10\% de SBF, $2 \mathrm{mM}$ de L-glutamina e 1 $\mu \mathrm{g} / \mathrm{ml}$ de ciclosporina A foram adicionados. O volume final de $10 \mathrm{ml}$ foi transferido para uma garrafa de cultura. Incubou-se a $37{ }^{\circ} \mathrm{C}, 5 \% \mathrm{CO}_{2}$ por três semanas.

\subsubsection{Cultivo de células imortalizadas por EBV}

Os linfócitos B imortalizados por EBV (EBV-B) foram mantidos na estufa a $37{ }^{\circ} \mathrm{C}$ e $5 \% \mathrm{CO}_{2}$, em meio RPMI Advanced, $10 \%$ soro fetal bovino (SFB), $100 \mathrm{U} / \mathrm{ml}$ de penicilina, $0,1 \mathrm{mg} / \mathrm{ml}$ de streptomicina e $2 \mathrm{mM}$ de glutamax. As células foram repicadas a cada três dias. 


\subsection{Métodos}

\subsubsection{Separação de linfócitos B ex-vivo por RosetteSep}

Para realizarmos a separação dos linfócitos B foram adicionados $50 \mu 1$ de RosetteSep Human B Cell Enrichment Cocktail (Stem Cell Technologies - Vancouver, Canada) por cada ml de sangue total em EDTA. Seguiu-se incubação de 20 minutos à temperatura ambiente. Após a incubação o sangue foi diluído em igual volume em PBS, contendo $2 \%$ de Soro Bovino Fetal (SBF) (Invitrogen Corporation - Carlsbad, CA, EUA). Essa mistura foi colocada cuidadosamente sobre o Ficoll-Paque (GE Healthcare - Uppsala, Suécia) de acordo com as instruções do fabricante e, em seguida, centrifugada por 20 minutos a 1200 xg à temperatura ambiente. Após a centrifugação, observou-se a formação de um anel contendo os linfócitos B. Esse anel foi recuperado e duas lavagens sucessivas foram feitas com PBS $2 \%$ SFB. O precipitado de células B foi colocado em meio de cultura RPMI (Invitrogen) e as células foram quantificadas e a viabilidade verificada pela utilização de Azul de Trypan (Cambrex Bio Science - Walkersville, MD, EUA).

\subsubsection{Extração do RNA e proteínas}

Células tratadas ou não tratadas foram submetidas à extração de RNA total e separação de proteínas usando o kit PARIS (Protein And RNA Isolation System, - Ambion). As células foram inicialmente centrifugadas a $300 \mathrm{xg}$ por 10 minutos para retirada do meio de cultura. Em seguida, foram lavadas com $1 \mathrm{ml}$ de PBS nas mesmas condições. Foi utilizado 25 $\mu \mathrm{L}$ de cada fração (citoplasmática e nuclear) para o isolamento de RNA. À mistura das duas frações foi adicionado o mesmo volume de 2X Lysis/Binding Solution (Ambion). Em seguida foi colocado o equivalente ao volume de lisado de etanol $100 \%$. Essa mistura foi colocada sobre uma coluna com filtro e centrifugada a 13000 xg por 1 minuto. Três lavagens subsequentes foram feitas com solução de lavagem na mesma velocidade e tempo de centrifugação. Na última etapa o filtro foi colocado em outro tubo e $40 \mu \mathrm{L}$ de solução de eluição previamente aquecida $\left(95{ }^{\circ} \mathrm{C}\right)$ foi adicionada ao filtro. O RNA total foi obtido após centrifugação de 13000 xg por 1 minuto. A concentração de cada amostra foi determinada pela leitura da densidade óptica no espectrofotômetro GeneQuant pro (GE Healthcare). 


\subsubsection{Preparação do cDNA}

O cDNA foi sintetizado utilizando o kit High Capacity RNA to cDNA (Applied Biosystems). Foi preparado um mix contendo por amostra: $10 \mu \mathrm{l}$ de tampão $2 \mathrm{X}$ RT, $1 \mu 1 \mathrm{de}$ enzima mix 20X RT e água livre de DNase e RNase em quantidade suficiente para $20 \mu 1$. Para cada reação foram utilizados $9 \mu \mathrm{l}$ do RNA e $11 \mu \mathrm{l}$ do mix previamente descrito. As amostras foram submetidas às seguintes temperaturas no termociclador: $37{ }^{\circ} \mathrm{C}$ por 60 minutos e $95{ }^{\circ} \mathrm{C}$ por 5 minutos.

\subsubsection{Reação em cadeia de polimerase (PCR) semi quantitativo}

Os cDNAs foram amplificados para o XBP total utilizando o termociclador PTC-100 Programmable Therma Controler (MJ Research). As temperaturas e os oligonucleotídeos utilizados encontram-se no quadro 3 e 4 , respectivamente.

Foi preparado um mix contendo:

A concentração final de $1 \mathrm{X}$ de Taq polimerase reation buffer

- 0,2 mM de oligonucleotídeo Foward (Tabela 4)

- 0,2 mM de oligonucleotídeo Reverse (Quadro 4)

$-0,2 \mathrm{mM}$ de dNTP

- 12,5U de Taq polimerase

- quantidade suficiente (qsp) de água livre de DNAse e RNAse para um volume final de $25 \mu \mathrm{l}$

As amostras foram incubadas no termociclador da seguinte maneira:

Quadro 3 - Programa de ciclagem PCR semi quantitativo

\begin{tabular}{|ccc|}
\hline Temperatura & Tempo & Ciclos \\
\hline $94{ }^{\circ} \mathrm{C}$ & $1 \mathrm{~min}$ & 01 \\
$94{ }^{\circ} \mathrm{C}$ & $1 \mathrm{~min}$ & 35 \\
$50{ }^{0} \mathrm{C}$ & $1 \mathrm{~min}$ & 35 \\
$72{ }^{0} \mathrm{C}$ & $1 \mathrm{~min}$ & 35 \\
$72{ }^{\circ} \mathrm{C}$ & $10 \mathrm{~min}$ & 01 \\
$4{ }^{0} \mathrm{C}$ & & 01 \\
\hline
\end{tabular}


Quadro 4 - Sequência dos oligonucleotídeos iniciadores utilizados na reação de PCR semiquantitativo

\begin{tabular}{|cc|}
\hline Nome & Sequência \\
\hline F - XBP & AAACAGAGTAGCAGCTCAGACTGC \\
R - XBP & GTATCTCTAAGACTAGGGGCTTGGTA \\
\hline
\end{tabular}

3.2.5 Fracionamento dos fragmentos amplificados em gel de agarose

Para verificar a amplificação dos genes de interesse nos PCRs realizados, as amostras foram submetidas à eletroforese em gel de agarose 3,0 ou 3,5\% em tampão 1X TAE (TrisAcetato-EDTA). Aplicou-se $10 \mu \mathrm{L}$ de cada amostra por poço em $1 \mathrm{X}$ tampão de amostra para DNA [10 mM Tris-HCl (pH 7,6), 0,03\% azul de bromofenol, 0,03\% xileno cianol, 60\% glicerol e $60 \mathrm{mM}$ EDTA](30). Padrões de peso molecular foram utilizados para verificação dos tamanhos dos fragmentos obtidos. A eletroforese foi realizada a $100 \mathrm{~V}$ constantes. Após o fracionamento, o gel foi corado com brometo de etídeo e fotodocumentado.

3.2.6 Reação em cadeia da polimerase (PCR) em tempo real (qPCR)

Os cDNAs foram amplificados para Ciclina A1, BiP, CHOP, EDEM, GRP94 e GAPDH utilizando o termociclador Mx3005P qPCR Systems (Stratagene) ou 7500 Fast-Real time PCR System (Applied Biosystems). As reações foram realizadas utilizando Fast SYBR ${ }^{\circledR}$ Green Master Mix (Applied Biosystems) e os dados foram analisados no programa MxPro ${ }^{\mathrm{TM}}$ QPCR Software ou no7500 Fast-Real time PCRSftware. A quantificação relativa dos produtos foi calculada pelo método $2-{ }_{\mathrm{T}}^{\Delta \Delta \mathrm{C}}$ utilizando o GAPDH como gene housekeeping. As sequências dos oligonucleotídeos utilizados foram desenhados utilizando o programa OligoPerfect da Invitrogen e encontram-se na quadro 5. 
Quadro 5 - Sequência dos oligonucleotídeos iniciadores utilizados na reação de qPCR

\begin{tabular}{|cc|}
\hline NOME & SEQUÊNCIA \\
\hline F-EDEM & 5'-AGAAAAATGCACCAGGATGG-3' \\
R-EDEM & 5'-AGGAAACAAGGCCCTCAGAT-3' \\
F-GRP94 & 5'-TGGATGTGGGAACAGATGAA-3' \\
R-GRP94 & 5'-ACATTCCCTCTCCACACAGG-3' \\
F-CHOP & 5'-CAGAACCAGCAGAGGTCACA-3' \\
R-CHOP & 5'-TCACCATTCGGTCAATCAGA-3' \\
F-BiP & 5'- CGAGGAGGAGGACAAGAAGG - 3' \\
R-BiP & 5'- CACCTTGAACGGCAAGAACT - 3' \\
F-Ciclina A1 & 5' - GCCACCTGCAGTTCTTCTTC - 3' \\
R-Ciclina A1 & 5' - CAACGTGCAGAAGCCTATGA -3' \\
F-GAPDH & 5' - ACCACAGTCCATGCCATCAC - 3' \\
R-GAPDH & 5' - TCCACCACCCTGTTGCTGTA - 3' \\
\hline
\end{tabular}

$\mathrm{O}$ método utilizado para análise da expressão do genes foi o $2^{-\Delta \Delta \mathrm{Ct}}$. Neste método os dados são representados como a expressão relativa do gene normalizada tanto pelo controle endógeno, no nosso caso o GAPDH, como pela amostra não tratada, no nosso caso a amostra "sem tratamento $0 \mathrm{~h}$ " (76).

$(\mathrm{Ct}$ alvo $-\mathrm{Ct}$ controle endógeno $) \mathrm{t}_{\mathrm{X}}-(\mathrm{Ct}$ alvo $-\mathrm{Ct}$ controle endógeno $) \mathrm{t}_{0}=\Delta \Delta \mathrm{Ct}$

Para as amostras não tratadas $\left(\mathrm{t}_{0}\right)$ o $\Delta \Delta \mathrm{Ct}$ é igual a 0 então o $2^{-\Delta \Delta \mathrm{Ct}}$ é igual a 1 , portanto por definição a expressão relativa do gene na amostra não tratada, no tempo 0 h, é igual a 1 . Considera-se que o tratamento induziu a expressão do gene alvo quando o $2^{-\Delta \Delta \mathrm{Ct}}$ é maior que 1. 
3.2.7 Ensaio de ciclo celular com Iodeto de Propídio

Um milhão de células $\left(1 \times 10^{6}\right)$ foram ressuspendidas em $200 \mu \mathrm{l}$ de PBS. A esta suspensão celular foram acrescentados $2 \mathrm{ml}$ de álcool $70 \%$ e incubadas por 30 min a $4^{\circ} \mathrm{C}$. As células foram centrifugadas, o precipitado ressupendido em $800 \mu \mathrm{l}$ de PBS, $100 \mu \mathrm{l}$ de RNase $(1 \mathrm{mg} / \mathrm{ml})$ e $100 \mu \mathrm{lde}$ PI $(400 \mathrm{mg} / \mathrm{ml})$ e incubadas por $30 \mathrm{~min}$ a $4{ }^{\circ} \mathrm{C}$ no escuro. As amostras foram adquiridas por citômetria de fluxo (FACS Canto) e os dados obtidos foram analisados no software FlowJo 9 (Tree Star, Inc.).

3.2.8 Ensaio de apoptose e necrose com AnexinaV-FITC e Iodeto de Propídio

Um milhão de células $\left(1 \times 10^{6}\right)$ foram cultivadas em meio RPMI completo $\left(10^{6}\right.$ cels $\left./ \mathrm{ml}\right)$ na presença de LPS (1 a $10 \mu \mathrm{g} / \mathrm{ml})$, Nocodazole $(20 \mu \mathrm{g} / \mathrm{ml})$, ou DTT (1 a $5 \mathrm{mM}$ ) por um período de 6 a 48 horas. As células foram mantidas na estufa a $37{ }^{\circ} \mathrm{C}$ e $5 \% \mathrm{CO}_{2}$. Após o período de incubação, foram lavadas duas vezes com PBS e ressuspendidas em Tampão de ligação (100 mM HEPES/NaOH, pH 7,5; 1,4 M NaCl e $25 \mathrm{mM} \mathrm{CaCl}_{2}$ ) na concentração de $1 \times 10^{6}$ células por ml. A esta suspensão foram acrescentadas Anexina V-FITC (Annexin VFITC Apoptosis Detection Kit -SIGMA) na concentração final de $5 \mathrm{mg} / \mathrm{ml}$ e Iodeto de Propídio na concentração final de $1 \mathrm{mg} / \mathrm{ml}$. As amostras foram incubadas por 10 minutos à temperatura ambiente e protegidas da luz. Em seguida, as amostras foram adquiridas em citômetro de fluxo (FACS Canto-BD) e os dados obtidos foram analisados no software FlowJo 9 (Tree Star, Inc.).

3.2.9 Proliferação celular com CFSE (5(6)-Carboxyfluorescein N-hydroxysuccinimidyl ester)

Para marcação, $5 \mu \mathrm{M}$ CFSE foi adicionado a suspensões unicelulares de células imortalizadas, numa concentração final de $1 \times 10^{6}$ células $/ \mathrm{ml}$ em PBS. Após 10 min de incubação a temperatura ambiente, foi adcionado 10 volumes de PBS com 5\% SFB, seguidos de centrifugação imediata a 300 xg, 5 min a $4{ }^{\circ} \mathrm{C}$. Foram feitas duas lavagens em PBS com 10\% SFB antes da ressuspensão das células em meio de cultura. Para os ensaios de proliferação, as células foram tratadas com diferentes estímulos e após os períodos desejados, a diluição do CFSE nas células-filhas foi analisada por citometria de fluxo.

3.2.10 Ensaio de viabilidade por MTT (3-(4-Dimethylthiazol-2yl)2,5 diphenyltetrazolium bromide) 
As células na concentração de $1 \times 10^{6}$ células/ml foram cultivadas na presença de LPS $(10 \mu \mathrm{g} / \mathrm{ml})$, por um período de 1 a 3 dias em uma placa de 96 poços. O sobrenadante foi descartado e as células ressuspendidas em $180 \mu \mathrm{l}$ de meio RPMI sem SFB e $20 \mu \mathrm{l}$ da solução de MTT (50 $\mu \mathrm{g} / \mathrm{ml}$ em DMSO). Em seguida, foram incubadas por 4 horas na estufa a $37{ }^{\circ} \mathrm{C}$ e $5 \% \mathrm{CO}_{2}$. Após a incubação, o sobrenadante foi removido e as células ressuspendidas em 200 $\mu 1$ de solução solubilizadora (20 ml de álcool isopropílico e $162 \mathrm{ml}$ de ácido clorídrico (37\%) diluídos em $20 \mathrm{ml}$ de uma solução Triton 10\%) e incubadas sob agitação por no mínimo 4 horas. A leitura foi realizada em um espectrofotômetro de placa a $570 \mathrm{~nm}$.

\subsubsection{Análises estatísticas}

As análises estatísticas foram realizadas com o auxílio do software GraphPad Prism, versão 5.0c (GraphPad Software). O teste estatístico utilizado foi o ANOVA, seguido pelo teste Bonferroni.

\subsection{Padronizações e Validação}

3.3.1 Padronização da técnica de Reação em Cadeia da Polimerase em tempo real (qPCR)

Inicialmente foi realizada a titulação dos oligonucleotídeos. Cento e vinte e cinco, 250 e $500 \mathrm{nM}$ de oligonucleotídeos por reação foram avaliados utilizando o Fast SYBR Green Master Mix (Applied Biosystem). A titulação dos primers é uma etapa importante, que deve ser realizada antes de iniciar as reações de PCR, uma vez que o excesso de primers leva à formação de primer dimers que aumentam o background da reação e também o Ct (Cycle Threshold). O Ct, é definido como o número de ciclos necessários para que um sinal fluorescente ultrapasse o limiar de detecção do aparelho.

As reações foram feitas em triplicatas para cada uma das concentrações de oligonucleotídeos. Quando cada triplicata amplifica no mesmo $\mathrm{Ct}$, indica reprodutibilidade técnica, o que foi observado no nosso caso.

A curva de dissociação é outro aspecto importante nas reações de PCR que utilizam a metodologia SYBR Green porque essa reação é inespecífica, ou seja, o fluoróforo pode se ligar a qualquer DNA dupla-fita. A curva de dissociação pode informar a presença de amplificações inespecíficas, como contaminação ou a presença de dímeros de 
oligonucleotídeos (primer dimers). Nesse caso a curva apresenta mais de um pico de dissociação.

Dessa forma, a tabela 1 resume a concentração ótima obtida para cada gene. Cada concentração foi escolhida baseando-se em reações com melhor reprodutibilidade técnica, menor $\mathrm{Ct}$ e ausência de primer dimers.

Tabela 1 - Concentração ótima dos oligonucleotídeos para cada gene

\begin{tabular}{cc}
\hline Gene & Título \\
\hline BiP & $500 \mathrm{nM}$ \\
CHOP & $500 \mathrm{nM}$ \\
EDEM & $500 \mathrm{nM}$ \\
GRP94 & $500 \mathrm{nM}$ \\
GADD34 & $250 \mathrm{nM}$ \\
Ciclina A1 & $500 \mathrm{nM}$ \\
Ciclina D1 & $250 \mathrm{nM}$ \\
GAPDH & $500 \mathrm{nM}$ \\
\hline
\end{tabular}

Após a titulação foi realizada a curva de eficiência de cada oligonucleotídeo com o título escolhido. A faixa aceitável da eficiência (E) da reação de um determinado gene deve estar entre 90 e $110 \%$, isso indica que na fase exponencial o produto duplica a cada ciclo de amplificação, ou seja, E=2. O ideal é que se utilizem amostras de cDNA em diferentes diluições de modo que se observe o comportamento da reação de uma concentração máxima até uma concentração mínima de molde (template). Neste procedimento foram utilizados os cDNAs puros e diluídos $(1 / 10 ; 1 / 100 ; 1 / 1000 ; 1 / 10000)$. A eficiência é calculada pelo ângulo formado pela reta (slope) da curva padrão e o eixo x, a partir da fórmula:

$$
\mathrm{E}=10^{(-1 / \text { slope })}-1
$$

Para alguns genes a eficiência da reação não alcançou as porcentagens desejadas (entre 90 e 110\%) e por isso esses oligonucleotídeos não são considerados prontos para uso. A reação deverá ser refeita. 
Tabela 2 - Valores de eficiência da reação para cada gene

\begin{tabular}{ccc}
\hline Gene & Eficiência(\%) & Pronto para uso? \\
\hline BiP & 102,34 & SIM \\
CHOP & 91,11 & SIM \\
EDEM & 92,28 & SIM \\
GRP94 & 96,55 & SIM \\
GADD34 & 120,78 & NÃO \\
Ciclina A1 & 110,10 & SIM \\
Ciclina D1 & 177,16 & NÃO \\
GAPDH & 95,82 & SIM \\
\hline
\end{tabular}

\subsubsection{Padronização da análise do ciclo celular}

A análise do ciclo celular de uma população pode ser feita através da marcação de DNA com iodeto de propídio, seguida pela leitura da fluorescência por citometria de fluxo. Células quiescentes ou em G1 têm apenas uma cópia de DNA (2N) e portanto intensidade de fluorescência 1X. Células em G2/M têm duas cópias de DNA (4N) e consequentemente intensidade $2 X$. Uma vez que as células na fase $S$ estão sintetizando DNA, estas terão valores de fluorescência variáveis entre as populações $1 \mathrm{X}$ e $2 \mathrm{X}$. O histograma resultante consiste de três populações: duas curvas de Gauss (picos $1 \mathrm{X}$ e $2 \mathrm{X}$ ) e a população na fase $\mathrm{S}$. As populações adjacentes se sobrepõem umas as outras, e por isso é necessário um programa de modelagem para atribuir valores percentuais para cada população. Os dados foram adquiridos utilizando o citômetro FACS Canto (BD) com o parâmetro PI-A (área). Na figura 5, está representada a análise realizada pelo software FlowJo, utilizando o modelo Dean-Jett-Fox. 
Figura 5 - Análise do ciclo celular pelo Flowjo

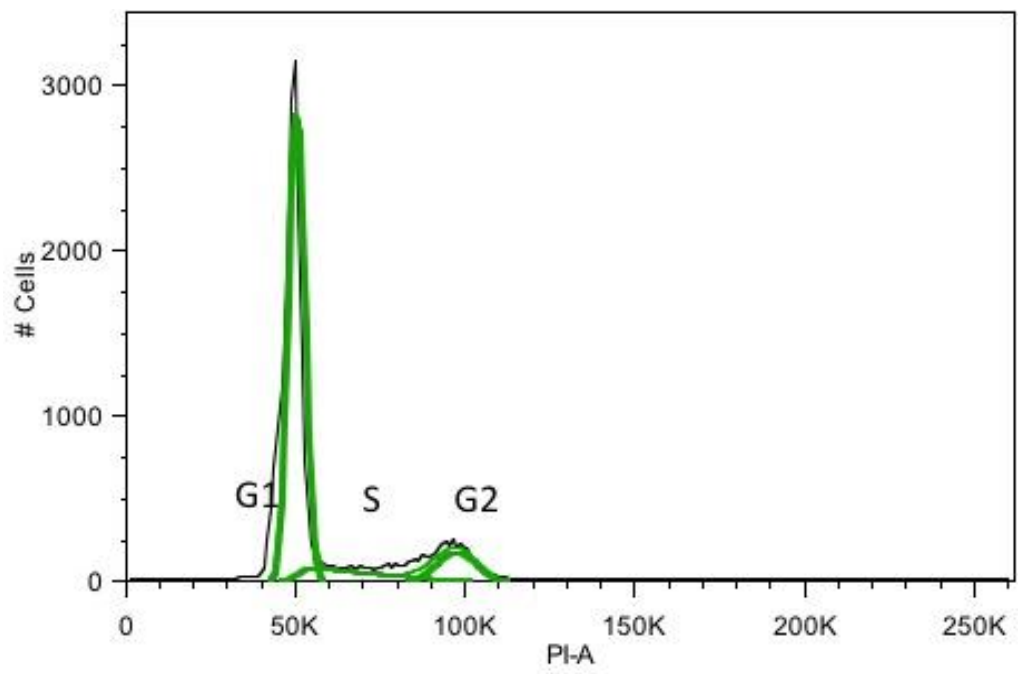

Representação gráfica da análise do ciclo celular feito pelo software FlowJo utilizando o modelo Dean-Jett-Fox. As células na fase G1 terão apenas uma cópia de DNA, células em G2/M terão duas cópias de DNA.

Com a finalidade de identificar a capacidade do método de distinguir alterações no ciclo celular foram realizados diferentes testes. Para tanto as células foram incubadas por 48 horas na presença de Nocodazol, que induz a parada do ciclo celular na fase G2-M, ou na presença de Hidroxiuréia, um agente antineoplástico que interfere na síntese de DNA durante a fase $\mathrm{S}$ retendo a maioria das células em G1 (apêndice A, Figura A.1). Assim, verificamos que foi possível distinguir as alterações no ciclo celular pela citometria de fluxo, uma vez que se observa o aumento do número de células em G1 nas amostras tratadas com Hidroxiuréia e em G2-M nas tratadas com Nocodazol. Contudo, o método apresentava uma desvantagem pois o aumento no número de células mortas, identificado pelo aumento no número de células que aparecem a esquerda de G1, interfere no cálculo do modelo. 
4 RESULTADOS E DISCUSSÃO 
Estabelecemos um sistema no qual os linfócitos B foram cultivados em diferentes condições, contendo ou não agentes que promovem o estresse do ER, pelo tempo de até 24 h. Em seguida, as células foram processadas simultaneamente para:

(i) análise do ciclo celular e apoptose por citometria de fluxo,

(ii) quantificação dos transcritos por PCR quantitativo (qPCR), para HSPA5 (heat shock 70kDa protein 5 ou BiP), DDIT3 (DNA-damage-inducible transcript 3 ou CHOP), EDEM1 (ER degradation enhancer, mannosidase alpha-like 1 ou EDEM), HSP90B1 (heat shock protein 90kDa beta (Grp94), member 1), CCNA1 (Ciclina A1) e GAPDH (glyceraldehyde-3-phosphate dehydrogenase)

A ativação da via UPR pode ser induzida por diferentes compostos que interferem na homeostasia do ER, tais como: tunicamicina (tun), tapsigargina (tg), e o dithiothreitol (DTT). Todas estas drogas causam estresse do ER, mas por diferentes mecanismos de ação.

A tunicamicina bloqueia a $\mathrm{N}$-glicosilação de proteínas causando o acúmulo no lúmen do ER de proteínas dobradas e não glicosiladas promovendo o estresse $(5,68)$.

A tapsigargina bloqueia a entrada de cálcio no ER. A depleção dos níveis deste íon provoca o estresse do ER ativando a via UPR (77).

O DTT promove a quebra das pontes disssulfeto, impedindo o dobramento de proteínas que necessitem dessa ligação. O DTT provoca o estresse por acúmulo de proteínas não dobradas no lúmen do ER. Ele foi o principal agente estressor utilizado nesse projeto, uma vez que é o único que provoca o estresse do ER pelo acúmulo de proteínas não dobradas. No caso da tunicamicina e da tapsigargina o estresse é causado pelo acúmulo e precipitação de proteínas já dobradas.

Decidimos comparar o efeito do estresse agudo e crônico causado pelo DTT em linfócitos B imortalizados com EBV (EBV-B). No estresse agudo, as células foram incubadas na presença de diferentes doses de DTT durante 1 hora, lavadas e mantidas em cultura por até 24 horas. No estresse crônico, o DTT foi mantido na cultura por todo o período da incubação (Quadro 6). 
Quadro 6 - Representação esquemática das condições de tratamento de estresse agudo e crônico

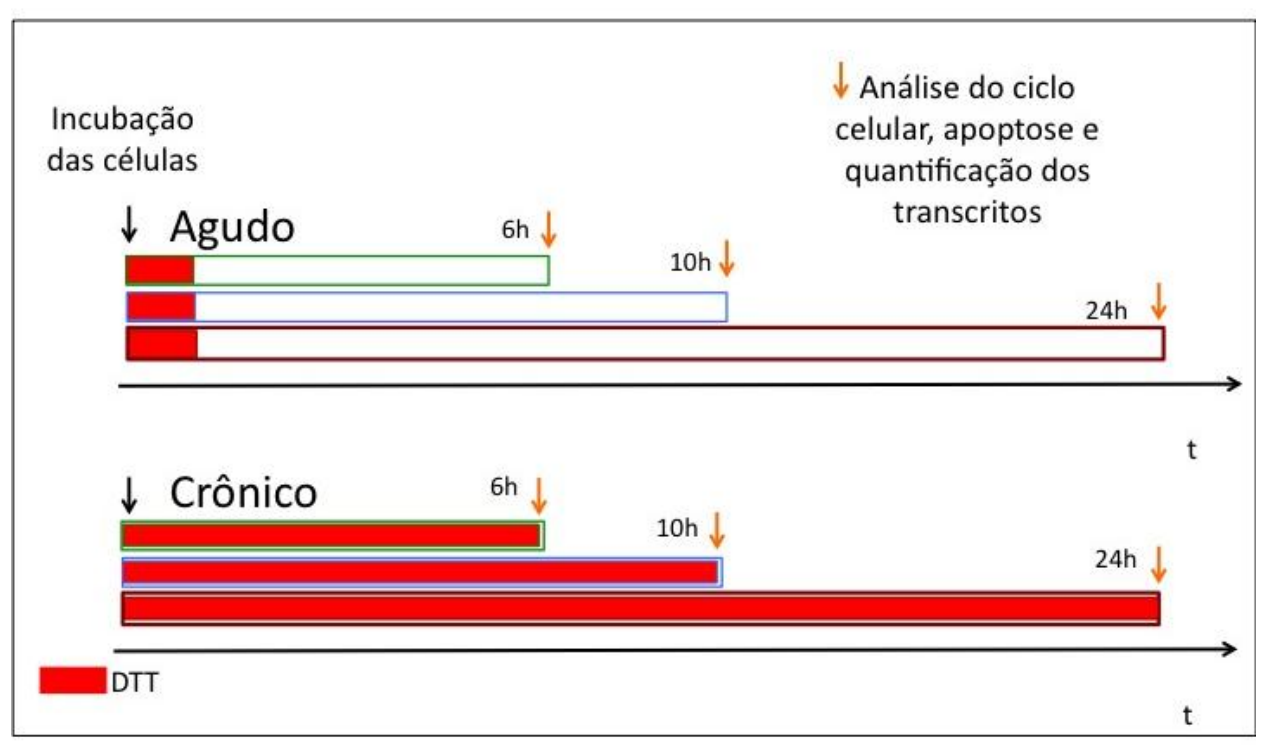

\subsection{Titulação do DTT como estressor do ER}

Com a finalidade de estabelecer a concentração de DTT a ser utilizada nos experimentos de estresse realizamos uma titulação. Para isso, os EBV-B de um indivíduo saudável (Controle 2) foram incubados na presença de diferentes doses de DTT, 0,05; 0,5; 5 e $10 \mathrm{mM}$, por $10 \mathrm{~h}$ seguindo o protocolo de estresse agudo e crônico. Em seguida, analisamos o ciclo celular, a expressão relativa dos genes BiP, CHOP e Ciclina A1 e também a apoptose de cada amostra.

\subsubsection{A dose de $5 \mathrm{mM}$ de DTT crônico provocou a parada do ciclo em $\mathrm{S}$}

O ciclo celular do Controle 2 (figura 6 e tabela 3) parece não ter sido afetado pelas menores doses de DTT $(0,05 \mathrm{mM}$ e $0,5 \mathrm{mM})$, tanto na condição de estresse agudo e crônico. De fato, verificamos que a porcentagem de células em cada fase do ciclo celular não é alterada pelos tratamentos.

No entanto, observamos que as maiores doses de DTT agudo (5 mM e $10 \mathrm{mM})$ promoveram a diminuição do número de células na fase $\mathrm{S}$ e o aumento na fase $\mathrm{G} 1$ do ciclo celular (tabela 3). Isso sugere que neste controle o tratamento agudo com DTT provoca a parada das células na fase G1, após 10 horas de incubação. Contudo, no estresse crônico este aumento do número de células na fase G1 não foi observado. Nas células tratadas com 
$5 \mathrm{mM}$ de DTT crônico a parada ocorreu na fase $\mathrm{S}$ do ciclo celular, uma vez que o tratamento promoveu um aumento de $24 \%$ para $33 \%$ no número de células na fase $\mathrm{S}$ (tabela 3). Na dose de $10 \mathrm{mM}$ de DTT crônico a análise foi impossibilitada pelo elevado número de células mortas.

Figura 6 - Análise do ciclo celular na titulação do estresse do ER causado por DTT

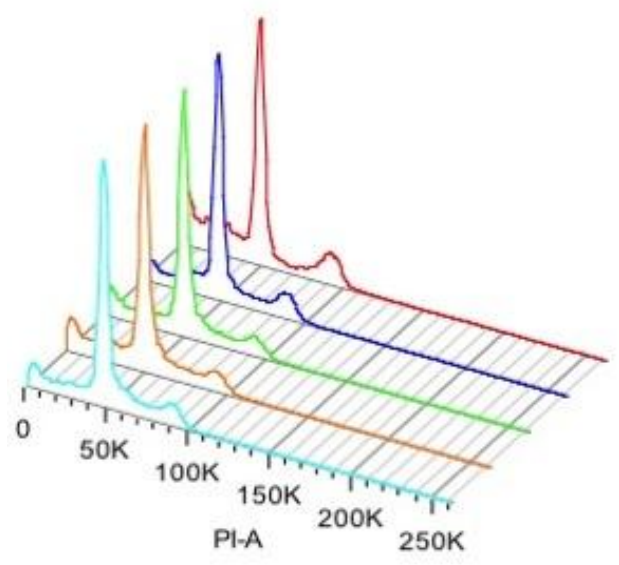

Agudo

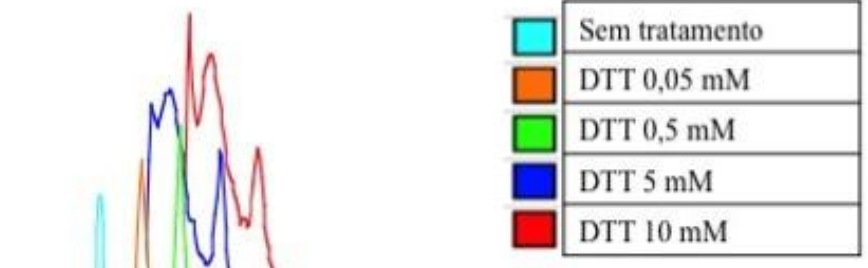

0
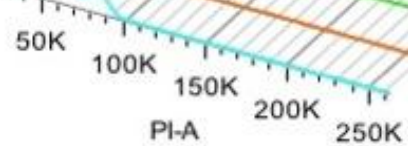

Crônico

A dose de $5 \mathrm{mM}$ de DTT agudo provocou um aumento do número de células na fase G1, enquanto que no tratamento crônico houve acúmulo na fase S. Os EBV-B do Controle 2 (L156) foram incubados com doses crescentes de DTT $(0,05 ; 0,5 ; 5$ e $10 \mathrm{mM})$ nas condições aguda ou crônica por $10 \mathrm{~h}$. As amostras foram marcadas com PI e analisadas por citometria de fluxo.

Tabela 3 - Porcentagem de células nas fases do ciclo celular após o tratamento com DTT

\begin{tabular}{ccccc}
\hline Tratamento & $\mathrm{mM}$ de DTT & $\% \mathrm{G} 1$ & $\% \mathrm{~S}$ & $\% \mathrm{G} 2$ \\
\hline \multirow{3}{*}{10 h Agudo } & - & 58 & 26 & 13 \\
& 0,05 & 57 & 26 & 13 \\
& 0,5 & 61 & 25 & 11 \\
& 5 & 63 & 18 & 15 \\
\hline \multirow{3}{*}{10 h Crônico } & 10 & 67 & 9 & 19 \\
& - & 58 & 24 & 13 \\
& 0,05 & 57 & 25 & 14 \\
& 0,5 & 63 & 20 & 13 \\
& 5 & 40 & 33 & 14 \\
\hline
\end{tabular}


4.1.2 A dose de $5 \mathrm{mM}$ de DTT crônico ativou a via UPR além de provocar um aumento na morte celular

$\mathrm{Na}$ análise da quantificação dos transcritos dos genes BiP, Ciclina A1 e CHOP (figura 7) podemos observar que, em geral, o estresse agudo não provocou a ativação da via UPR após $10 \mathrm{~h}$ de tratamento. Durante o estresse agudo, o aumento (expressão relativa maior que 1) da transcrição de BiP e Ciclina A1 foi mínimo e não houve um aumento na transcrição de CHOP.

Figura 7 - Expressão relativa dos genes BiP, CHOP e Ciclina A1 após a indução da via UPR com DTT
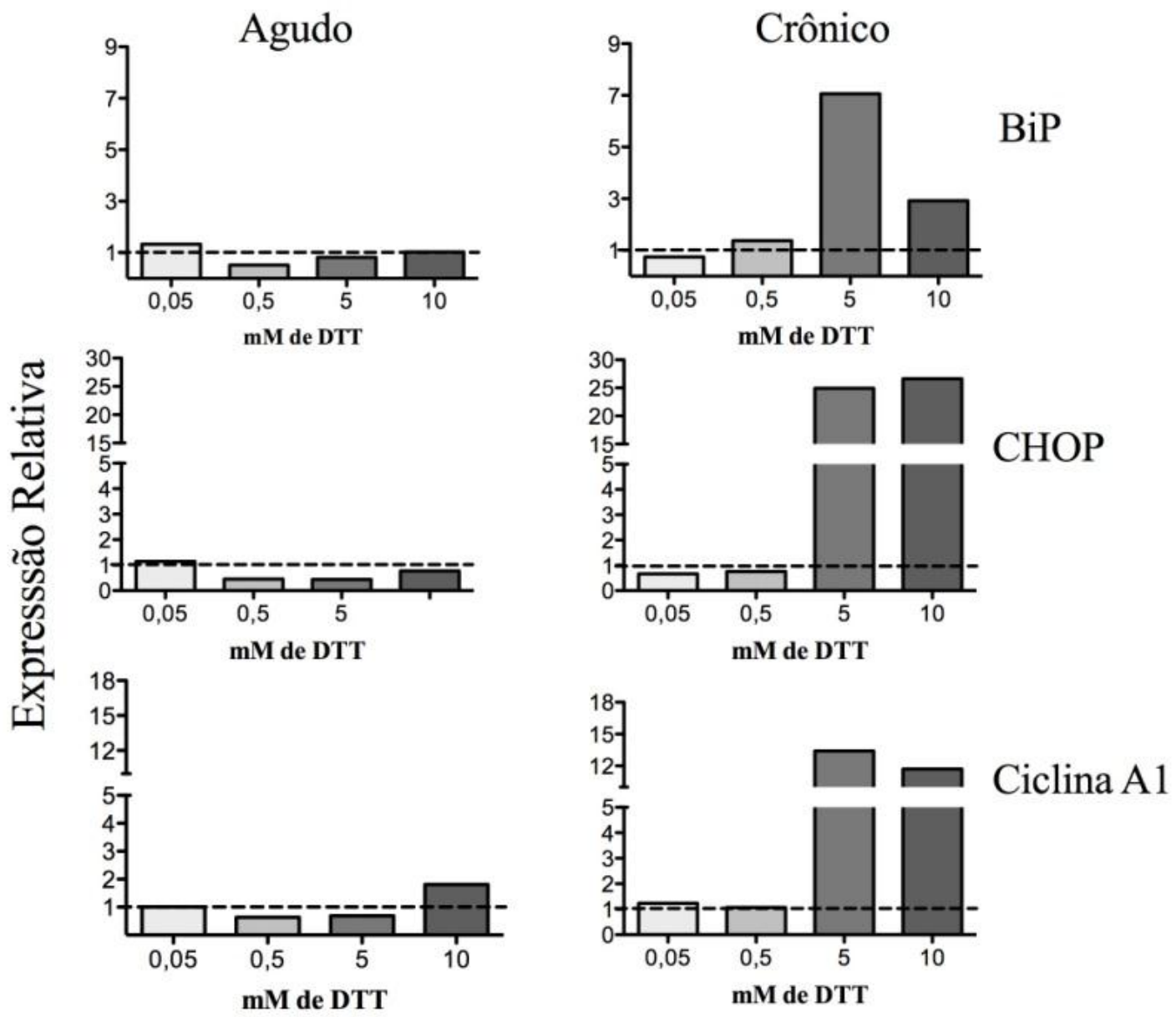

A dose de $5 \mathrm{mM}$ de DTT crônico ativou a via UPR e aumentou os transcritos de Ciclina A1Os EBV-B do Controle 2 (L156) foram incubados com doses crescentes de DTT $(0,05 ; 0,5 ; 5$ e 10 $\mathrm{mM}$ ) nas condições aguda ou crônica por 10 horas. No gráfico, está representada a expressão relativa por $2^{-\Delta \mathcal{L}^{C} \mathrm{t}}$. 
Durante a indução do estresse crônico, houve um aumento na expressão relativa de BiP, o qual foi mais pronunciado na dose de $5 \mathrm{mM}$ de DTT (aproximadamente 8 vezes maior do que no controle não tratado). Nesta concentração de DTT também houve aumento da transcrição de Ciclina A1 e de CHOP (13 e 25 vezes, respectivamente).

Considerando que CHOP é um fator pró-apoptótico, o aumento da sua expressão relativa pode estar relacionado com o maior número de células mortas (pico à esquerda de G1, figura 6 e A.1). De fato, observamos que durante a incubação crônica com 5 mM de DTT, houve um aumento de 25 vezes na transcrição de CHOP, que pode ser correlacionado com uma elevação na morte celular de 18\% para 66\% (tabela 4).

Tabela 4 - Porcentagem de células mortas após o tratamento com DTT

\begin{tabular}{cccc}
\hline & Dose de DTT & \% vivas & \% mortas \\
\hline Sem Tratamento & - & 82 & 18 \\
\hline \multirow{3}{*}{ Agudo } & 0,05 & 78 & 22 \\
& 0,5 & 80 & 19 \\
& 5 & 81 & 19 \\
& 10 & 69 & 30 \\
\hline \multirow{2}{*}{ Crônico } & 0,05 & 82 & 18 \\
& 0,5 & 83 & 16 \\
& 5 & 34 & 66 \\
& 10 & 32 & 68 \\
\hline
\end{tabular}

Com base nos resultados descritos acima, verificamos que para o Controle 2, a dose de $5 \mathrm{mM}$ de DTT foi capaz de interferir no ciclo celular. Quando esta dose foi utilizada, houve acúmulo de células em G1 após o estresse agudo, e em S após o estresse crônico. Observamos também que na condição crônica ocorreu ativação da via UPR, uma vez que houve aumento na transcrição de BiP e CHOP. Além disso, foi verificado o acúmulo dos transcritos de Ciclina A1. Por fim, encontramos uma relação entre a indução de CHOP e o aumento da morte celular. Portanto, nos experimentos seguintes utilizamos a dose de 5 $\mathrm{mM}$ tanto na indução aguda quanto crônica do estresse do ER. 
4.2 Avaliação e comparação do estresse agudo e crônico induzido por DTT em linfócitos B imortalizados de indivíduos saudáveis e linhagens tumorais

Para comparar a ativação da via UPR e seu efeito sobre o ciclo celular nas condições de estresse agudo e crônico induzido por DTT, utilizamos os EBV-B de dois controles saudáveis: Controle 1 (Piedade) e Controle 2 (L156); e de duas linhagens tumorais: a Tumoral 1 (Raji, CCL-86) e a Tumoral 2 (Toledo, CRL-2631). As células Tumoral 1 e 2 são linfócitos B provenientes de linfomas non-Hodgkins (quadro 1), diferindo apenas pelo fato da linhagem Tumoral 1 ser uma forma incomum e mais agressiva desse linfoma (Burkitt), que comumente afeta crianças.

Após as otimizações, os experimentos foram realizados da seguinte forma: as células que se encontravam em cultura foram centrifugadas e ressuspendidas na concentração de $1 \times 10^{6}$ células/ml. Após estes procedimentos, as células foram incubadas nas condições de estresse agudo ou crônico com 5mM de DTT (quadro 6).

\subsubsection{O estresse crônico com $5 \mathrm{mM}$ de DTT provocou maior ativação da via UPR}

Nestes ensaios analisamos a expressão relativa de BiP nos diferentes controles (Controle 1 e 2 e Tumoral 1 e 2) nas condições sem tratamento, 5 mM de DTT agudo e 5 mM de DTT crônico (figura 8).

$\mathrm{Na}$ condição sem tratamento foi observado um aumento na transcrição de BiP apenas nas células EBV-B do Controle 1. Este aumento foi maior após $6 \mathrm{~h}$ de incubação (40 vezes). Entretanto, quando estas células foram tratadas com DTT, tanto na condição aguda quanto na crônica, verificou-se um aumento ainda maior na transcrição de BiP. Na condição aguda, a expressão relativa de BiP aumentou 120 vezes e na crônica 133 vezes. Estes resultados indicam que a transcrição de BiP foi induzida pelo tratamento com DTT, mesmo em uma linhagem na qual já ocorre uma expressão relativa basal (figura 8) .

Também podemos observar um padrão no aumento da expressão relativa da $\mathrm{BiP}$. Quando induzimos o estresse agudo com $5 \mathrm{mM}$ de DTT, observou-se um pico na expressão relativa de BiP após 6 h e, em seguida, uma diminuição. Esta observação sugere que ocorreu o desligamento da via UPR como uma consequência da retirada do agente estressor. No entanto, quando o estresse é induzido em condições crônicas com $5 \mathrm{mM}$ de DTT, houve um aumento dos transcritos de BiP após 6 h (Controle 1: 133 vezes ; Controle 2: 16 vezes; Tumoral 1: 4,7 vezes e Tumoral 2: 4,8 vezes), uma diminuição em $10 \mathrm{~h}$ 
(Controle 1: 93,3 vezes; Controle 2: 1,1 vezes; Tumoral 1: 1,4 vezes e Tumoral 2: 2,2 vezes) seguida de um novo aumento após 24 h (Controle 1: 108 vezes; Controle 2: 5,9 vezes; Tumoral 1: 3,4 vezes e Tumoral 2: 11,2 vezes) (Figura 8).

Figura 8 - A transcrição de BiP após a indução do estresse com $5 \mathrm{mM}$ de DTT é maior na condição crônica.

\section{$\mathrm{BiP}$}

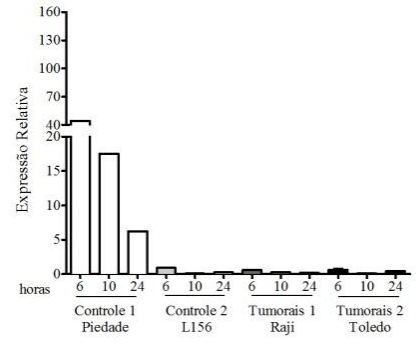

Sem tratamento

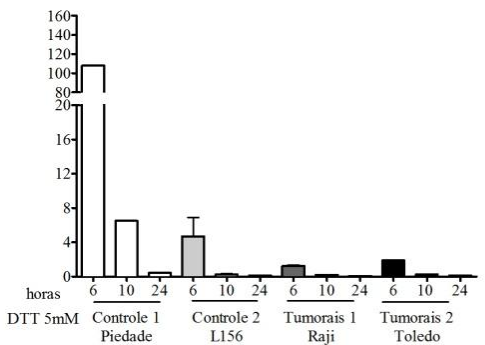

Agudo

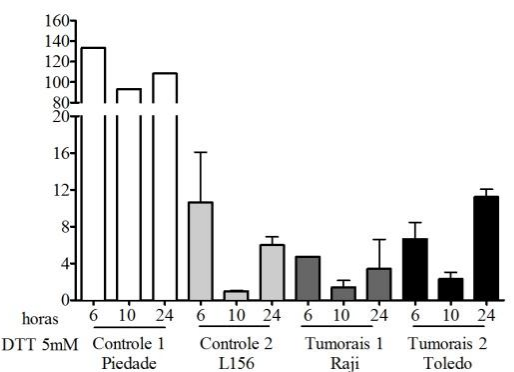

Crônico

Expressão relativa de BiP após a indução aguda e crônica da via UPR. Os linfócitos B imortalizados foram incubados por 6, 10 e 24 horas na presença de $5 \mathrm{mM}$ de DTT. No gráfico, está representada a expressão relativa por $2^{-\Delta \Delta \mathrm{Ct}}$

Durante o estresse crônico há um aumento da transcrição de BiP em todas as linhagens estudadas, sendo esse maior nas células EBV-B dos controles que nas tumorais. Estes resultados sugerem que os controles são menos resistentes e mais responsivos ao estresse causado pelo DTT. Além disso, a via UPR parece estar intrinsecamente ativada no Controle 1, uma vez que se observou o aumento da expressão relativa de BiP mesmo na ausência de tratamento. Entretanto, na presença de estresse, o aumento da transcrição de BiP nesse controle foi maior. Observamos também a ocorrência de splicing do XBP1 a partir de 6 h de incubação com DTT, com um pico após 10 h (Apêndice C, Figura C.1).

A via UPR está altamente induzida em diversos tipos de tumores e está associada com o prognóstico e a resistência aos tratamentos antineoplásicos (78). Células cancerosas possuem metabolismo rápido de glicose e uma alta taxa de crescimento, o que leva a pobre vascularização da massa tumoral, baixa oferta de oxigênio, e a privação de nutrientes (79). Além disso, as células cancerosas podem expressar proteínas mutantes que podem não ser corretamente dobradas. Estas características podem causar o estresse do ER e consequentemente a ativação da via UPR. Evidências crescentes sugerem que a via UPR fornece sinais de sobrevivência necessários para o crescimento do tumor (78, 80-82). 
As linhagens Tumorais utilizadas em nosso estudo, apresentaram uma menor transcrição de $\mathrm{BiP}$, quando comparadas com os controles, e por isso parecem ser mais resistentes ao estresse da via UPR causado pelo DTT. No entanto, o padrão de ativação da via é similar em todas as linhagens.

4.2.2 A transcrição de CHOP está correlacionada com o aumento da morte celular nas células controles

Como discutido anteriormente, a CHOP é um fator pró-apoptótico cuja transcrição é regulada pelo braço PERK da via UPR (47). Deste modo, decidimos efetuar ensaios para quantificar a expressão relativa de CHOP e a avaliar a morte celular nas linhagens controles e tumorais. Em todas as linhagens observamos que não houve aumento na expressão relativa de CHOP na ausência de estresse (figura 9). No entanto, durante o tratamento agudo, observou-se um pequeno aumento na transcrição de CHOP, mas este não foi acompanhado pela elevação do número de células mortas (Apêndice C, Tabela C.1, C.2, C.3 e C.4).

Figura 9 - A transcrição de CHOP após a indução do estresse com 5 mM de DTT é maior na condição crônica e está correlacionada com o aumento da morte celular nas células controles

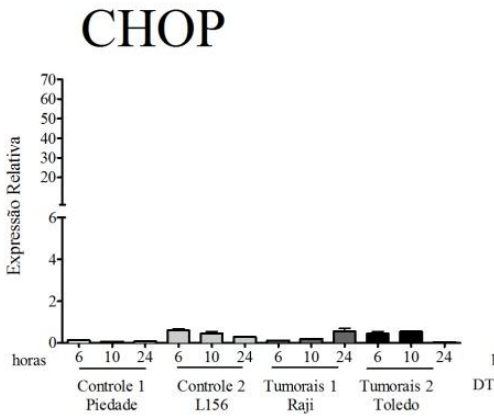

Sem tratamento

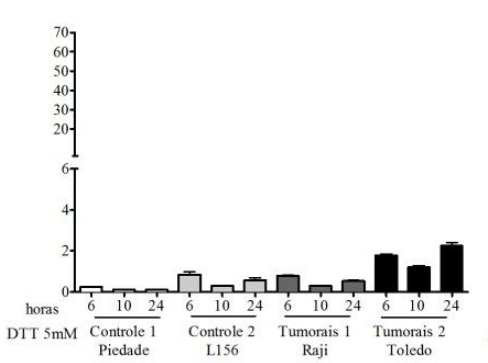

Agudo

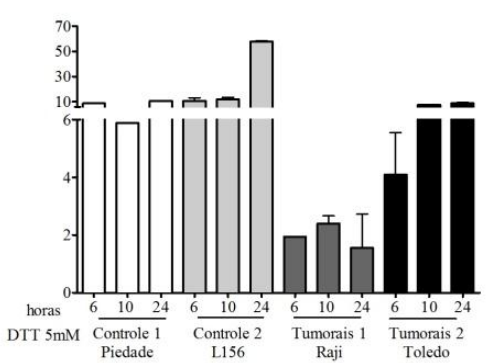

Crônico

Expressão relativa de CHOP após a indução aguda e crônica da via UPR com $5 \mathrm{mM}$ DTT. Os linfócitos B imortalizados foram incubados por 6,10 e 24 horas na presença de $5 \mathrm{mM}$ de DTT. No gráfico, está representada a expressão relativa por $2^{-\Delta \Delta C t}$.

Por outro lado, durante a ativação crônica da via UPR com DTT, verificou-se um aumento nos transcritos de CHOP. Esse aumento foi maior nas células do Controle 2, após $24 \mathrm{~h}$ de tratamento (50 vezes), e pode ser correlacionado com o aumento da apoptose, que nesse controle chegou a $82 \%$ (figura 10 e apêndice C). Podemos observar também uma 
elevação dos transcritos de CHOP nas células Tumoral 1 e 2 ( 3 e 10 vezes, respectivamente) (figura 9). No entanto, o aumento da expressão relativa de CHOP é menor nas linhagens tumorais do que aquele observado nos controles (figura 10 e apêndice C).

As células EBV-B dos controles se mostraram muito mais sensíveis ao estresse da via UPR, tanto o causado pela incubação aguda quanto crônica com DTT, do que as células tumorais (figuras 8 e 9). Quando comparamos a expressão relativa de CHOP com a morte celular ao longo do tempo (figura 10 e apêndice $\mathrm{C}$ ), verificamos que à medida que a expressão de CHOP aumenta, também ocorre um aumento no número de células mortas.

Por exemplo, quando comparamos as amostras sem tratamento com as tratadas com $5 \mathrm{mM}$ de DTT crônico após $24 \mathrm{~h}$ de incubação, observamos que o número de células mortas do Controle 1 aumentou de $22 \%$ para $40 \%$, e do Controle 2 de $22 \%$ para $82 \%$, (figura 10 e tabelas C.1, C.2, C.3 e C.4 do apêndice C). É importante ressaltar que foram observadas células mortas mesmo na ausência de tratamento, sendo que aproximadamente $25 \%$ das células dos Controles 1 e 2 estavam mortas no ponto 0 h (tabelas C. 1 e C.2). No entanto, durante o tratamento agudo a porcentagem de células mortas não foi alterada, assim como também não se observou o aumento da expressão relativa de CHOP (tabelas C.1 e C.2). Estes resultados indicam uma correlação entre o aumento da expressão relativa de CHOP e o aumento da morte celular.

Estudos anteriores demostraram que a CHOP participa da via UPR mediando a morte celular. A superexpressão de CHOP promove a parada do ciclo celular e apoptose (46). Além disso, camundongos deficientes de CHOP são parcialmente resistentes à apoptose mediada pelo estresse do ER (47). 
Figura 10 - As células dos controles saudáveis são mais sensíveis à morte celular induzida por CHOP
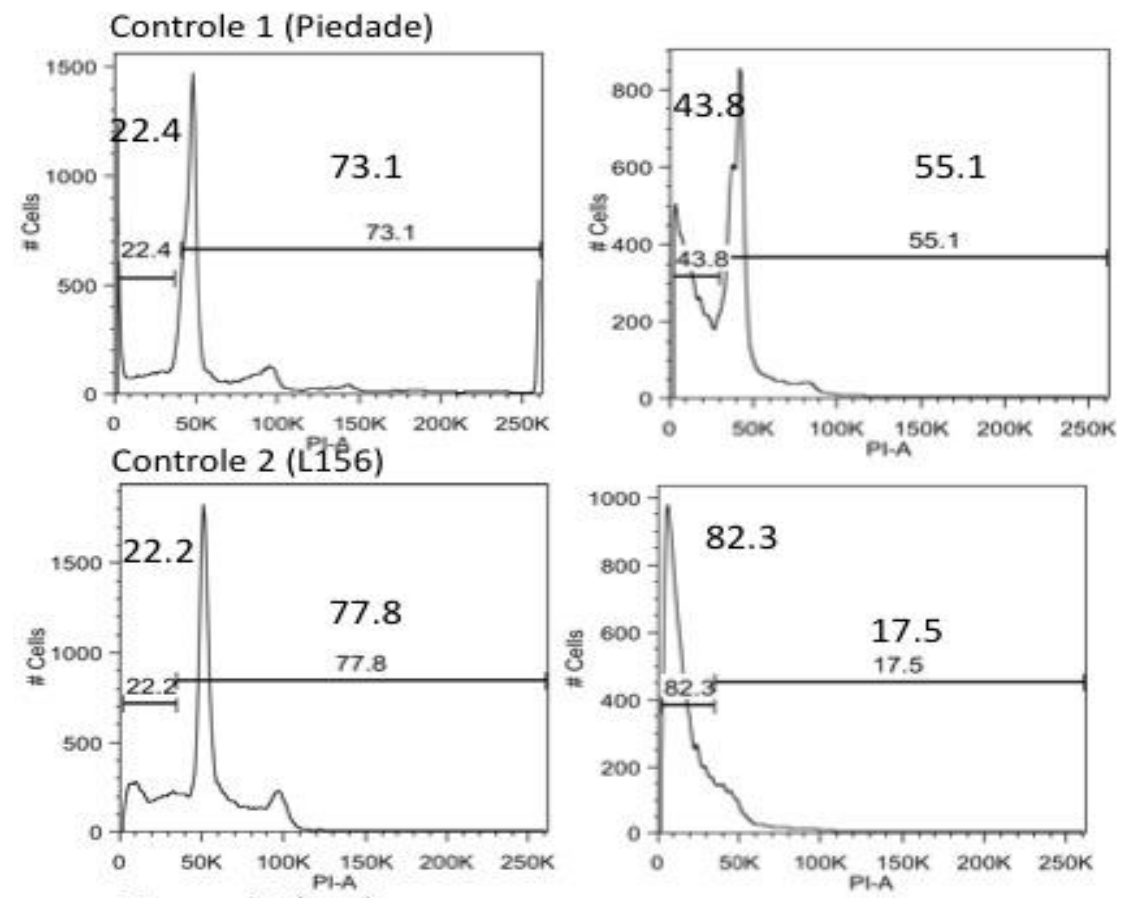

$24 \mathrm{~h}$
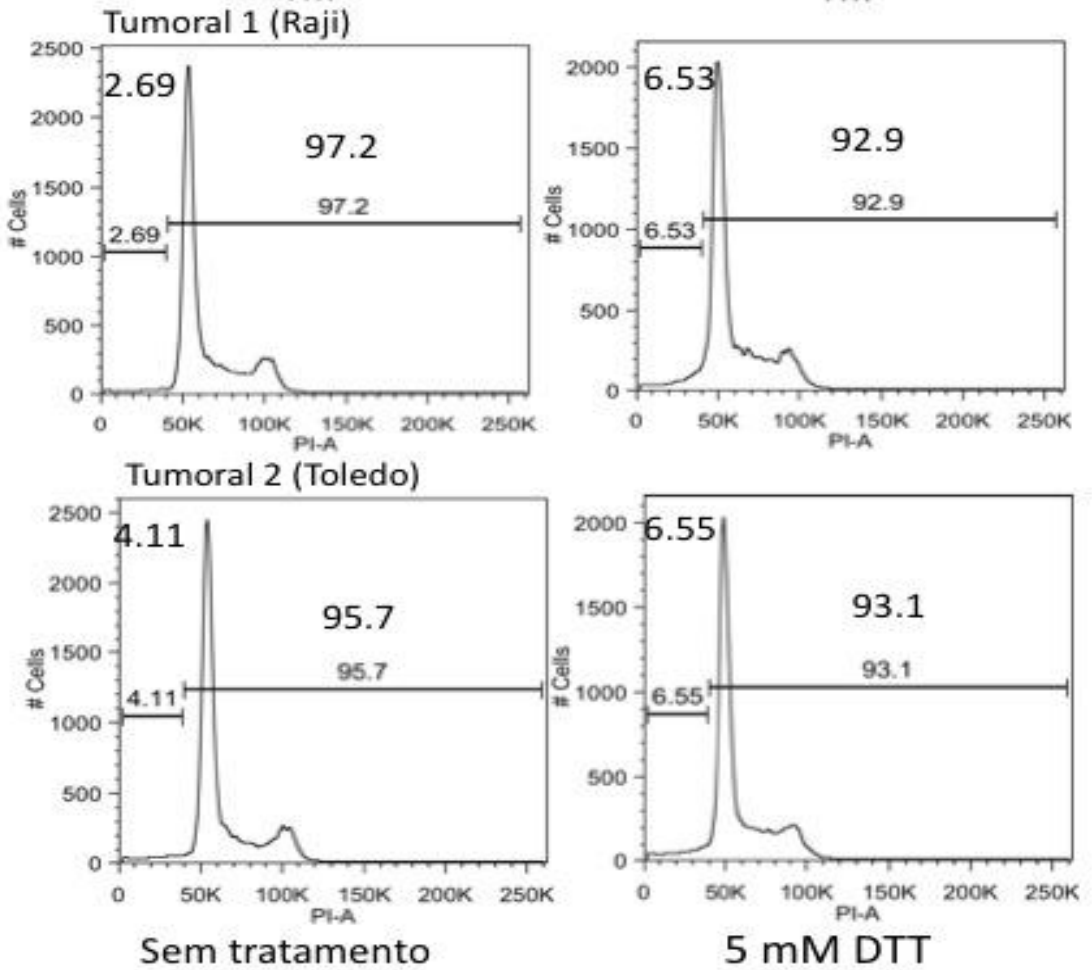

Morte celular dos EBV-B após $24 \mathrm{~h}$ de incubação com $5 \mathrm{mM}$ de DTT crônico. As células foram incubadas com DTT $5 \mathrm{mM}$ por $24 \mathrm{~h}$ e depois marcadas com PI para a análise do ciclo celular. Células com menos de $2 \mathrm{~N}$ de DNA são consideradas mortas (gate da esquerda). 
A condição de estresse crônico foi capaz de ativar o braço da PERK da via UPR e, consequentemente, aumentar a expressão de CHOP induzindo a morte celular. Entretanto, observamos que as células tumorais apresentaram uma menor porcentagem de morte celular do que os controles, mesmo quando a indução de CHOP foi semelhante. Podemos sugerir que as células tumorais são capazes de reverter a morte celular induzida por CHOP.

Embora a ativação da via UPR seja essencial na diferenciação de linfócitos B em plasmócitos (19), não existe atualmente qualquer evidência da ativação de PERK durante essa diferenciação (72). Além disso, camundongos $\mathrm{RAG}^{2} \%$ reconstituídos com células de fígado fetal hematopoiéticas, que têm o eIF2 $\alpha$ não fosforilável (eIF2 $\alpha$ S51A), apresentaram células-B esplênicas maduras e níveis normais de imunoglobulinas no soro. Este fato sugere que a fosforilação de eIF2 $\alpha$ promovida pela PERK pode ser dispensável para o desenvolvimento de plasmócitos in vivo. Foi observado também que os linfócitos B se desenvolvem normalmente em camundongos Perk $\%$ (83).

Além disso, em células B esplênicas de camundongos tratadas com LPS foi observada a expressão do fator de transcrição do XBP1s a partir do primeiro dia de incubação, com o pico de ativação no segundo dia, o qual foi mantido até o quarto dia. A forma ativa do ATF6 foi observada a partir do segundo dia de tratamento com LPS. Entretanto, não foi observada a presença de PERK ativada (fosforilada) durante os 4 dias de incubação com LPS. Isso sugere que a diferenciação de linfócitos B em plasmócitos envolve um tipo de UPR que inclui a ativação de IRE e ATF6, mas não de PERK (84). Sendo assim, a ativação da UPR durante a diferenciação dos plasmócitos é distinta da UPR presente em outros tipos de células secretoras especializadas e em células sujeitas a estresse do ER induzido farmacologicamente. A atenuação na tradução de proteínas mediada pela ativação da PERK seria contraprodutiva nos plasmócitos, uma vez que essas células precisam sintetizar e secretar grandes quantidades de imunoglobulinas. Diferentemente dos plasmócitos, o braço da PERK parece ser ativado nas células tumorais do nosso estudo. Porém o aumento da expressão relativa de CHOP não está diretamente relacionado com o aumento da morte celular, contudo, essa relação é muito clara nas células dos controles. 
4.2.3 A ativação da via UPR e a transcrição de Ciclina A1 estão relacionadas com a parada do ciclo celular

Em relação a expressão relativa de Ciclina A1 observamos que os picos de trancrição relativa ocorreram em diferentes períodos quando comparamos as diferentes linhagens. As ciclinas são proteínas reguladoras do ciclo celular e, juntamente com as cdks regulam a transição entre as diferentes fases do ciclo celular (54), portanto esta diferença entre as linhagens era esperada, uma vez que possuem uma taxa de proliferação distinta e não estavam sincronizadas. Sendo assim, não notamos nenhum padrão de expressão da Ciclina A1, entre as diferentes linhagens, na análise sem tratamento (figura 11).

No entanto, o tramento com DTT $5 \mathrm{mM}$ alterou a expressão relativa de Ciclina A1 quando comparamos individualmente cada linhagem tratada com o controle sem tratamento. Por exemplo, após $6 \mathrm{~h}$ em cultura sem tratamento, a expressão relativa de Ciclina A1 foi de aproximadamente 2 vezes o valor basal nas células do Controle 2. Quando estas foram tratadas com $5 \mathrm{mM}$ de DTT agudo, essa expressão aumentou para 10 vezes. As células foram incubadas na mesma placa e processadas simultaneamente, ou seja, esta alteração na expressão relativa de Ciclina A1 em um mesmo período de incubação é, provavelmente, consequência direta da ativação da via UPR pelo tratamento com DTT.

Figura 11 - Distúrbio na transcrição de Ciclina A1 após a indução do estresse com $5 \mathrm{mM}$ de DTT agudo e crônico

\section{Ciclina A1}

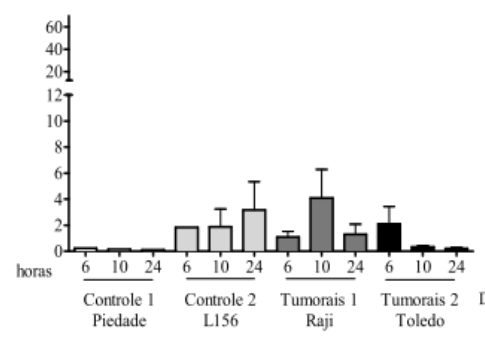

Sem tratamento

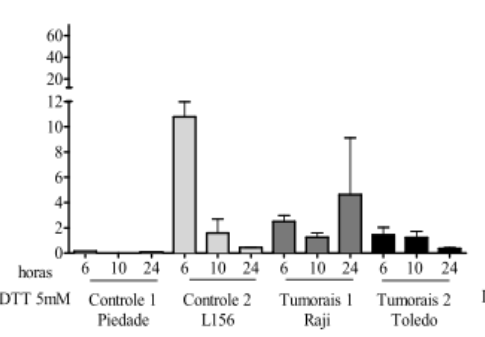

Agudo

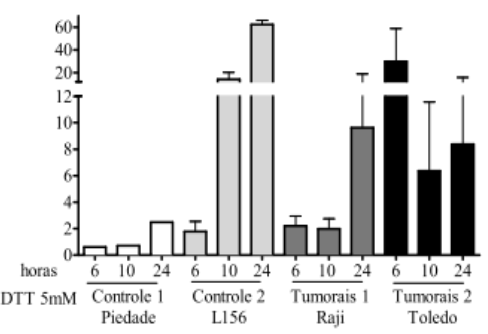

Crônico

Os linfócitos B imortalizados foram incubados por 6, 10 e 24 horas na presença de $5 \mathrm{mM}$ de DTT agudo ou crônico. No gráfico, está representada a expressão relativa por $2^{-\Delta \Delta \mathrm{Ct}}$. Distúrbio na expressão relativa de Ciclina A1 após a indução aguda e crônica da via UPR com 5 mM DTT. 
Nesta figura, notamos que os níveis dos transcritos de Ciclina A1 se mantiveram altos durante todo o período da incubação crônica com DTT (figura 11). Este aumento nos níveis dos transcritos de Ciclina A1 poderia interferir na natureza cíclica da proteína Ciclina A1, provocando um distúrbio no ciclo celular. Este distúrbio poderia causar a interrupção do ciclo celular e o acúmulo das células em uma fase específica. No entanto, até o momento não sabemos se o aumento nos transcritos de Ciclina A1 é correspondente a aumentos na expressão da proteína Ciclina A1.

Na figura 11, observamos que o aumento contínuo na expressão relativa de Ciclina A1 após o tratamento com DTT crônico coincide com os pontos de ativação da via UPR, observados anteriormente pelo aumento dos transcritos de BiP e CHOP (figura 8 e 9). Este aumento também coincide com a parada das células na fase G1 ou S do ciclo celular (figura 12 e tabela 5).

Foi realizado também as análises do ciclo celular de todas as linhagens, e na figura 12 foram representadas apenas as análises do ponto 10 horas, os demais pontos são apresentados nas figuras C.2 e C.3 (apêndice C). Podemos observar que o distúrbio na transcrição de ciclina e a ativação da via UPR causa a interrupção do ciclo celular, o que pode ser verificado através do acúmulo das células em uma determinada fase do ciclo celular. Esse acúmulo ocorre em fases diferentes do ciclo celular, dependendo tanto do tipo celular quanto da condição do tratamento, agudo ou crônico.

Podemos observar na tabela 5 que no Controle 1 , o tratamento com $5 \mathrm{mM}$ de DTT agudo provocou a parada das células na fase G1 do ciclo celular (6 h: 77\%; 10 h: 77\% e 24 h: 76\%), apesar de não ter ocorrido um aumento na transcrição relativa de Ciclina A1 (figura 11). Por outro lado, o tratamento agudo parece não causar qualquer alteração no ciclo celular das células tumorais e do Controle 2.

Quando olhamos para o tratamento com $5 \mathrm{mM}$ de DTT crônico, verificamos que esse provocou um aumento no número de células na fase $\mathrm{S}$, no caso das linhagens Tumorais (Tumoral 1: 6 h: 28\%, 10 h: 29\% e 24 h: $34 \%$; Tumoral 2: 6 h: $26 \%, 10$ h: $26 \%$ e 24 h: $36 \%$ ) e na fase G1 no caso do Controle 1 (6 h: 43\%, 10 h: $47 \%$ e 24 h: 53\%;). Na análise do Controle 2, observou-se uma tendência para o acúmulo das células na fase G2; entretanto, os dados podem não ser fidedignos, uma vez que o número de células mortas nesse experimento é muito elevado e pode ter comprometido a análise $(82 \%$, figura $10 \mathrm{e}$ apêndice C). Além disso, foi observado em outro experimento (tabela 3) que o tratamento com $5 \mathrm{mM}$ de DTT crônico provocou a parada das células do Controle 2 na fase $S$, e não em G2 como no experimento anterior (figura 12). Como discutido anteriormente o número 
de células mortas nestes experimentos foi muito elevado, sendo de $82 \%$ e $66 \%$ respectivamente (figura 10 e tabela 4), podendo ter comprometido a análise. Em contrapartida, quando observamos os experimentos realizados com as linhagens tumorais houve uma grande reprodutibilidade experimental e um número baixo de células mortas.

Figura 12 - O estresse do ER provocado pelo tratamento com DTT causa a parada do ciclo celular em G1 na condição aguda e em S e G2 na condição crônica

Controle 1 (Piedade)

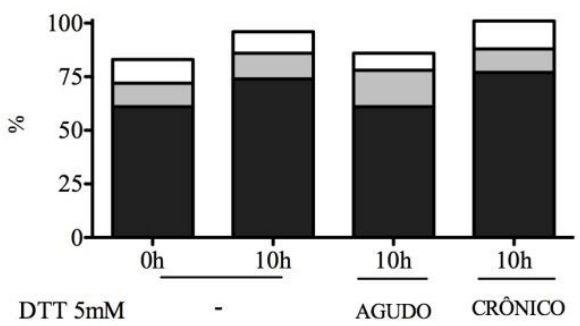

Tumorais 1 (Raji)

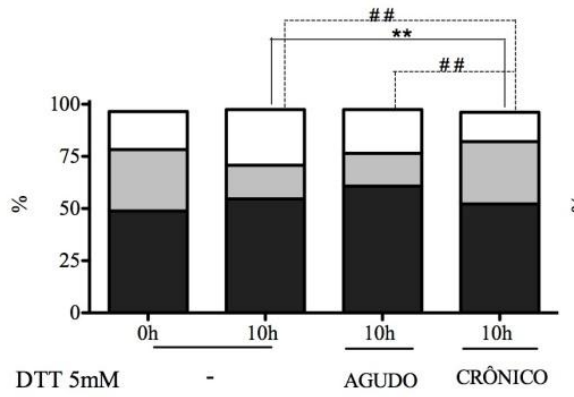

Controle 2 (L156)

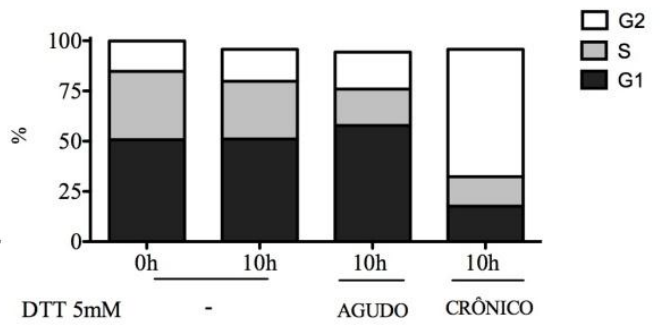

Tumorais 2 (Toledo)

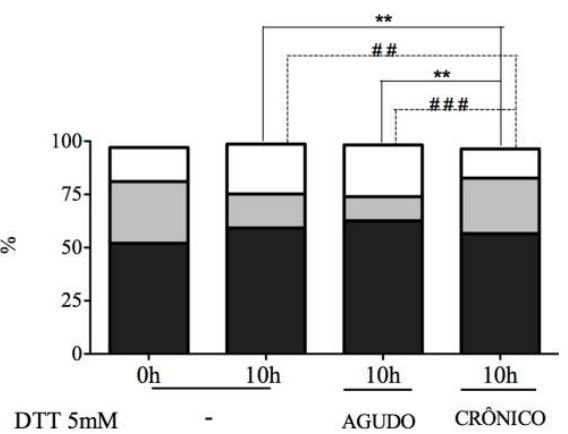

Porcentagem de células em cada fase do ciclo celular após 10 horas de incubação com DTT 5 mM agudo e crônico. As células imortalizadas foram incubadas ou não com DTT $5 \mathrm{mM}$ por 6,10 e 24 horas. No gráfico apresenta-se apenas o resultado da incubação por 10 horas. *ou $\# \mathrm{p} \leq 0,01$; **ou $\# \# \mathrm{p} \leq 0,001 ; * * *$ ou \#\#\# $\mathrm{p} \leq 0,0001$. Sendo que o * simboliza a diferença entre as fases $\mathrm{G} 2$, e o \# entre as fases $\mathrm{S}$. 
Tabela 5 - Acúmulo de células do Controle 1 e Tumoral 1 e 2 após a indução da UPR com $5 \mathrm{mM}$ de DTT

\begin{tabular}{|c|c|c|c|c|c|c|}
\hline Tratamento & Linhagem & Tempo & $\% \mathrm{G} 1$ & $\% \mathrm{~S}$ & $\% \mathrm{G} 2$ & Acúmulo \\
\hline & & $\mathrm{Oh}$ & 61 & 11 & 12 & - \\
\hline $5 \mathrm{mM}$ de DTT & Controle 1 & $6 \mathrm{~h}$ & 77 & 14 & 12 & \\
\hline \multirow[t]{5}{*}{ Agudo } & (Piedade) & $10 \mathrm{~h}$ & 77 & 11 & 13 & G1 \\
\hline & & $24 \mathrm{~h}$ & 76 & 5 & 13 & \\
\hline & Controle 1 & $6 \mathrm{~h}$ & 43 & 31 & 14 & \\
\hline & (Piedade) & $10 \mathrm{~h}$ & 47 & 26 & 13 & G1 \\
\hline & & $24 \mathrm{~h}$ & 53 & 14 & 6 & \\
\hline $5 \mathrm{mM}$ de DTT & & $0 \mathrm{~h}$ & 49 & 27 & 18 & - \\
\hline \multirow[t]{7}{*}{ Crônico } & Tumorais 1 & $6 \mathrm{~h}$ & 53 & 28 & 14 & \\
\hline & (Raji) & $10 \mathrm{~h}$ & 52 & 29 & 14 & S \\
\hline & & $24 \mathrm{~h}$ & 46 & 34 & 14 & \\
\hline & & $0 \mathrm{~h}$ & 50 & 27 & 15 & - \\
\hline & Tumorais 2 & $6 \mathrm{~h}$ & 55 & 26 & 16 & \\
\hline & (Toledo) & $10 \mathrm{~h}$ & 56 & 26 & 13 & S \\
\hline & & $24 \mathrm{~h}$ & 41 & 36 & 18 & \\
\hline
\end{tabular}

Nas linhagens Tumorais foi possível observar que, durante o estresse crônico, as células que se encontram na fase $S$ após $6 \mathrm{~h}$ de incubação parecem continuar nessa fase mesmo após 10 e $24 \mathrm{~h}$ (tabela 5). Exceto por um pequeno aumento na porcentagem das células Tumorais 2 em G2 após 24 h de tratamento (de $13 \%$ em 10 h para $18 \%$ em 24 h) e, como consequência, uma diminuição na porcentagem de células em G1 (de 55\% em 6 h para $41 \%$ em $24 \mathrm{~h}$ ) (tabela 5). Essas alterações podem indicar que as células estão entrando na fase $S$, mas parece haver um distúrbio na passagem das células para G2-M, diferentemente do que estaria acontecendo com o Controle 1, onde as células não passam para a fase $S$.

$\mathrm{Na}$ tentativa de entender melhor estes dados, realizamos a análise da transição relativa ao ponto $0 \mathrm{~h}$ das fases do ciclo celular (figura 13, 14 e 15). A transição relativa da fase $\mathrm{G} 1$ para a fase $\mathrm{S}$ foi calculada a partir da porcentagem de células em $\mathrm{S}$ em cada ponto de tratamento menos a porcentagem de células em $\mathrm{S}$ no ponto $0 \mathrm{~h}$ (figura 13). A partir 
destes cálculos podemos concluir se o tratamento fez com que as células passassem de G1 para $\mathrm{S}$ (aumento na transição relativa), ou se as células permaneceram na fase G1 do ciclo celular (diminuição da transição relativa). Se a transição relativa G1-S aumentar com passar do tempo de incubação, significa que as células estão passando da fase G1 para a fase $\mathrm{S}$. Ou seja, que a porcentagem de células na fase $\mathrm{S}$ no ponto $0 \mathrm{~h}$ é menor do que nos pontos seguintes. Devemos ressaltar que as células não foram sincronizadas e, portanto, as linhagens encontravam-se em fases diferentes do ciclo celular no início do experimento.

Figura 13 - Transição relativa de G1 para S
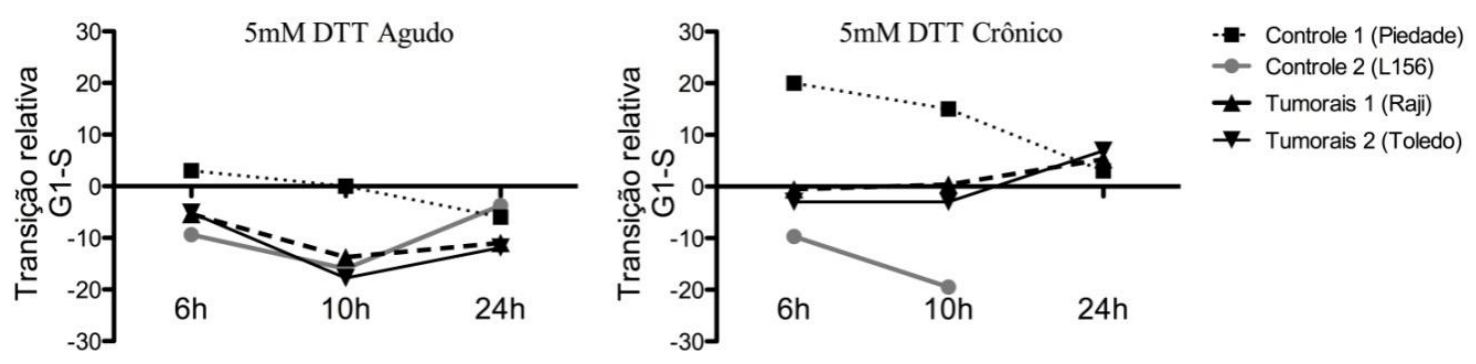

O DTT $5 \mathrm{mM}$ causa a diminuição da transição relativa de G1 para S no Controle 1, e o aumento da transição de G1 para S na condição crônica, nas linhagens tumorais. As células imortalizadas foram incubadas ou não com DTT $5 \mathrm{mM}$ por 6,10 e $24 \mathrm{~h}$. No gráfico, apresenta-se a transição relativa de G1 para $S$, que foi calculada pela porcentagem de células em $\mathrm{S}$ em cada ponto subtraindo a do ponto $0 \mathrm{~h}$.

Novamente podemos observar que o tratamento agudo provocou a parada de células na fase G1 do ciclo celular, principalmente no Controle 1 (Piedade), no qual o número de células na fase G1 do aumenta com o passar do tempo de incubação. Este acúmulo de células nessa fase é devido à diminuição da transição relativa G1-S durante o período de tempo em que as células ficaram incubadas (figura 13).

Durante a ativação crônica da via UPR nas linhagens tumorais podemos observar que houve um aumento da porcentagem de células na fase $\mathrm{S}$ do ciclo celular. É possível observar um aumento na transição relativa de células da fase G1 para a fase S (figura 13) e, como consequência, o aumento na porcentagem de células em $\mathrm{S}$ (tabela 5).

Na figura 14, observamos a transição relativa de S para G2 em todas as linhagens. A transição relativa foi calculada a partir da porcentagem de células em G2 em cada ponto de tratamento menos a porcentagem de células em $\mathrm{G} 2$ no ponto $0 \mathrm{~h}$. 
Figura 14 - Transição relativa de S para G2
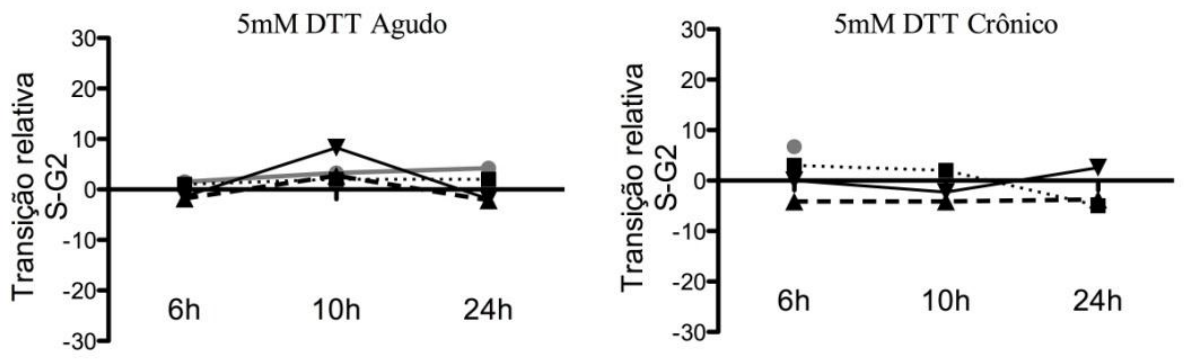

Controle 1 (Piedade)

Controle 2 (L156)

- Tumorais 1 (Raji)

$\rightarrow$ Tumorais 2 (Toledo)

O estresse do ER provocado pelo tratamento com $5 \mathrm{mM}$ de DTT causa a parada do ciclo celular em G1 na condição aguda e em S e G2 na condição crônica. As células imortalizadas foram incubadas ou não com DTT $5 \mathrm{mM}$ por 6,10 e $24 \mathrm{~h}$. No gráfico, apresenta-se a transição relativa de $\mathrm{S}$ para G2, que foi calculada pela porcentagem de células em G2 em cada ponto subtraindo a do ponto $0 \mathrm{~h}$.

Podemos observar que a transição relativa de células da fase S para G2 praticamente não foi alterada pelo tempo de incubação durante a ativação crônica nas células Tumorais 1 e 2. Exceto por um pequeno aumento já mencionado anteriormente na porcentagem de células em G2 nas Tumorais 2 após 24 h com DTT crônico. Outro fato importante é que as poucas células do Controle 1 que conseguiram entrar em S, após 6 h de DTT crônico (figura 13), passaram para G2, e a transição relativa foi diminuindo assim como a de G1 para S (figura 14).

Por fim, na figura 15 podemos visualizar a transição relativa de G2 para G1. Esta foi calculada utilizando a porcentagem de células na fase G1 nos pontos 6, 10 e $24 \mathrm{~h}$ subtraindo essa porcentagem no ponto $0 \mathrm{~h}$.

Figura 15 - Transição relativa de G2 para G1
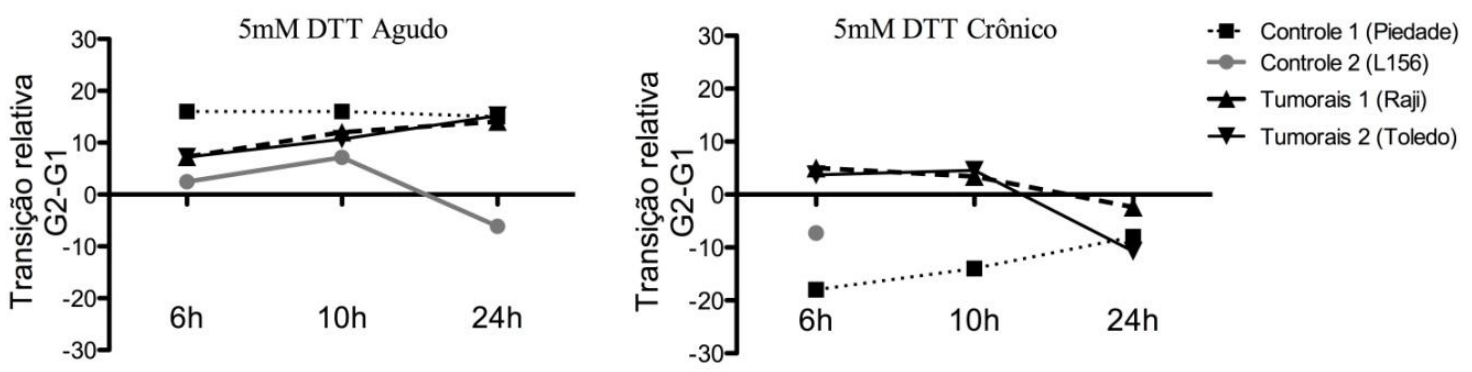

O estresse do ER provocado pelo tratamento com $5 \mathrm{mM}$ de DTT agudo acumula as células na fase G1 do ciclo celular. As células imortalizadas foram incubadas ou não com DTT $5 \mathrm{mM}$ por $6,10 \mathrm{e}$ 24 h. No gráfico, apresenta-se a transição relativa de G2 para G1, que foi calculada pela percentagem de células em $\mathrm{G} 1 \mathrm{em}$ cada ponto subtraindo à do ponto $0 \mathrm{~h}$. 
No Controle 1, é possível observar que não houve alteração na transição relativa de G2 para G1, mostrando que com o aumento do tempo de incubação as células pararam de entrar em S (Figura 13), e parte delas entrou em G2 (figura 14). No ponto $6 \mathrm{~h}$ a maior porcentagem de células entrou e permaneceu na fase G1 do ciclo. Durante a incubação crônica com DTT, as células que se encontravam em G2 chegaram na fase G1 do ciclo celular, mas a passagem de G1 para S foi prejudicada (figura 13 e tabela 5).

Nas Tumorais, o tratamento com DTT crônico provocou o acúmulo de células na fase S do ciclo. As células que estavam na fase G1 passaram para a fase S (figura 13). Entretanto, a passagem de S para G2 foi prejudicada (figura 14). Além disso, após 24 h de tratamento, observa-se um pequeno aumento na porcentagem de células na fase G2 em decorrência da diminuição da transição relativa de G2 para G1 (tabela 5).

Observou-se que o comportamento das células em relação ao ciclo celular é mais heterogêneo do que a ativação da via UPR. Consideramos que essa variação possa ser consequência das diferentes taxas de proliferação de cada linhagem celular e do fato das células estarem em fases diferentes do ciclo celular quando foram estimuladas com DTT. No entanto, as tentativas de sincronização do ciclo celular realizadas durante este estudo não foram bem sucedidas (apêndice D).

Nossos experimentos mostraram que a intensidade de ativação da via UPR, a taxa de morte celular e o efeito do DTT no ciclo celular são dependentes tanto do tipo celular quanto da duração do estresse. Entretanto, devemos ressaltar o comportamento atípico das células do Controle 1, que parecem possuir a UPR intrinsecamente ativada cuja expressão de Ciclina A1, além de baixa, não responde ao aumento da ativação da via UPR. O comportamente deste controle foi diferente do observado nas demais linhagens (figura 8, 9 e 11).

As células dos controles utilizadas em nosso estudo são linfócitos B separados a partir de sangue periférico de indivíduos saudáveis e, posteriormente, imortalizadas por infecção com o vírus EBV. O vírus EBV é um vírus de DNA dupla fita da família do herpesvírus. Durante a fase latente esse vírus expressa 9 proteínas importantes para a sua manutenção e do linfócito B infectado. Entre essas proteínas está a proteína latente de membrana 1 (LMP-1), que é capaz de inibir a apoptose regulando positivamente a expressão do gene BCL2 e A20 (85). O LMP-1 é um oncogene que mimetiza o receptor CD40 e é capaz de ativar a via de sinalização do NFkB. A expressão da proteína LMP-1 é essencial para a proliferação de linfoblastos infectados por EBV (85). É sabido que os níveis de expressão dessa proteína podem variar fisiologicamente dependendo da linhagem 
celular infectada e do período de infecção. Células que expressam níveis muito elevados ou muito reduzidos da proteína LMP-1 possuem a proliferação celular diminuída. Altas concentrações da proteína LMP-1 correlacionam-se com a menor incorporação de BrdU pelas células e portanto à baixa síntese de DNA. Além disso, essas células acumulam-se na fase G1 do ciclo celular. O aumento dos níveis de LMP-1 está relacionado com o aumento da fosforilação do fator de iniciação eucariótico 2 (eIF2 $\alpha$ ) (86). Clones infectados com EBV e que expressam níveis fisiologicamente altos de LMP-1 possuem níveis altos de eIF2 $\alpha$ fosforilado. O LMP-1 promove o aumento dos níveis de eIF2 $\alpha$ fosforilado pois é capaz de ativar a PERK através da ativação da via UPR (87). A ativação da via UPR induzida pelo estresse do ER com tunicamicina levou ao aumento da expressão de LMP-1, que tem sua transcrição aumentada pelo fator de transcrição ATF4. A ativação da UPR promovida pelo LMP-1 é dependente da concentração dessa proteína, ou seja, quanto maior os níveis de LMP-1 maior a ativação da via UPR promovida pela mesma (87).

As células do Controle 1 parecem ter a via UPR intrinsecamente ativada, e quando o estresse do ER é promovido pela incubação com DTT a expressão relativa de BiP aumenta e as células se acumulam na fase G1 do ciclo celular (figura 8,11, 12 e tabela 5). Sendo assim, uma hipótese é que a ativação intrínseca da UPR nestas células pode também ser consequência de uma alta expressão de LMP-1, uma vez que as células encontram-se na fase G1 do ciclo celular e a expressão de Ciclina A1 encontra-se baixa em todos os períodos analisados.

Levando em conta os dados da literatura e os nossos achados, podemos vislumbrar que a relação entre a via UPR e o ciclo celular depende tanto da célula quanto do tipo de estresse. Os mecanismos causadores da deficiência da proliferação dos EBV-B do Paciente $\mathrm{P}$ e em outros pacientes com CVID podem estar envolvidos com a baixa ativação da via UPR (61). Uma UPR deficiente não permitiria o aumento da transcrição da proteína LMP1, o que poderia causar a diminuição nos níveis dessa proteína e consequentemente diminuição da taxa de proliferação dessas células. Por outro lado, o aumento dos níveis fisiológicos da proteína LMP-1 também causaria a diminuição da proliferação, mas neste caso deveríamos observar uma UPR intrinsecamente ativada nos EBV-B do Paciente P e não uma deficiência na ativação. 
4.3 Ativação da via UPR e estudo do ciclo celular com outras drogas estressoras de ER

Em linfócitos B imortalizados por EBV o estresse da via UPR, provocado pelo tratamento com DTT, induz a parada do ciclo celular em G1 na condição aguda, e em S e G2 na condição crônica. Essa parada é dependente da linhagem celular e provavelmente da fase em que o ciclo celular se encontra quando as células são estressadas. A parada do ciclo celular em consequência da ativação da via UPR parece também ser depende do estímulo. Existem na literatura trabalhos que mostram a parada das células na fase G1 do ciclo celular como consequência da indução crônica da via UPR com drogas como a tunicamicina $(40,68)$ e tapsigargina (77). Para verificarmos essa hipótese, realizamos um experimento onde tanto células EBV-B do Controle 3 quanto da linhagem Tumoral 1 foram estressadas com $250 \mathrm{nM}$ de tapsigargina.

\subsubsection{A tapsigargina induz a parada do ciclo celular em G1}

Na figura 16, observou-se que as células do Controle 3 e da Tumoral 1 tiveram o número de células em G1 aumentado após a incubação com $24 \mathrm{~h}$ de tapsigargina. A porcentagem de células na fase G1 do ciclo celular aumenta de $41 \%$ para $68 \%$ nas células Tumoral 1 e de $47 \%$ para $60 \%$ nas células do Controle 3.

Figura 16 - Parada das células na fase G1 do ciclo celular após o estresse do ER provocado pela incubação com tapsigargina por $24 \mathrm{~h}$
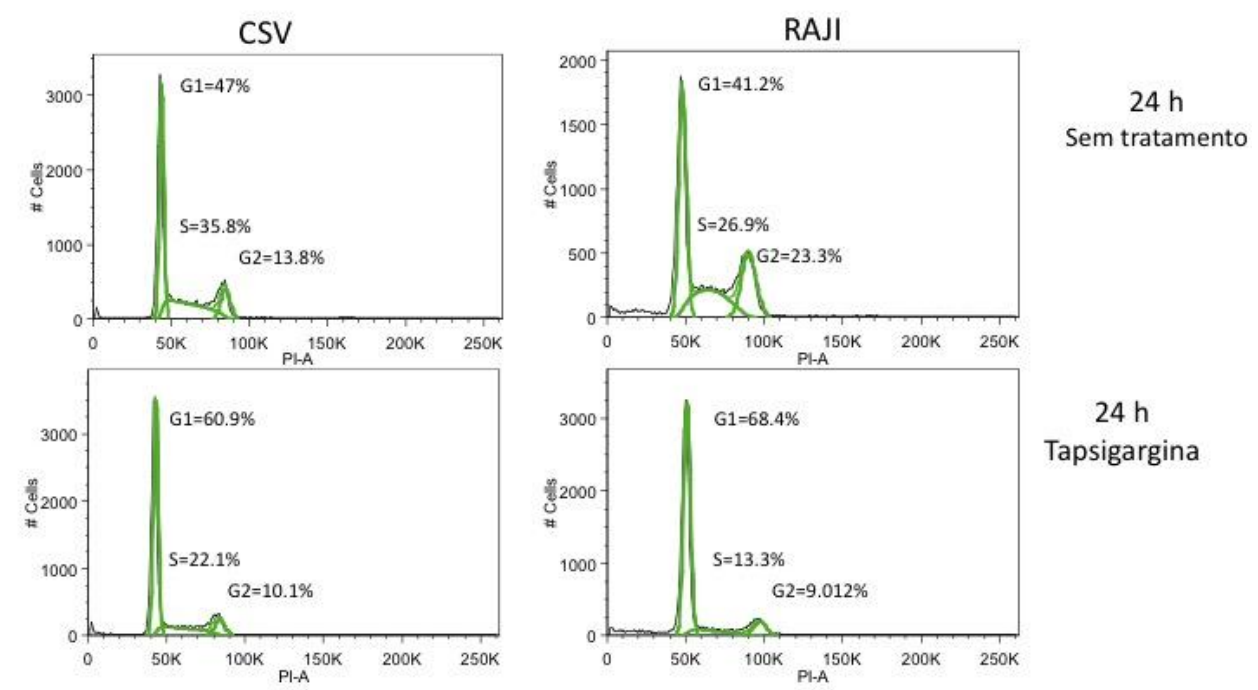

$24 \mathrm{~h}$

Tapsigargina

Análise do ciclo celular após a incubação com $250 \mathrm{nM}$ de tapsigargina crônico. As células foram fixadas e marcadas com PI para a análise de ciclo celular por citometria de fluxo 
O DTT, a tunicamicina e a tapsigargina são estressores conhecidos do ER, entretanto o mecanismo de ação dessas drogas é diferente. A tunicamicina bloqueia a Nglicosilação de proteínas, causando o acúmulo de proteínas dobradas e não glicosiladas. A tapsigargina bloqueia a entrada de cálcio no ER e a depleção dos níveis desse íon provoca o estresse ativando a via UPR. Por sua vez, o DTT age quebrando as pontes dissulfeto impedindo o dobramento de proteínas que necessitem dessa ligação.

É importante entender que drogas com mecanismos de ação diferentes provocam reações diferentes no ciclo celular, apesar de todas serem consideradas estressoras de ER (figura 12, tabela 5 e figura 16). Entretanto devemos considerar que a maior diferença nos mecanismos de ação do DTT e da tapsigargina é que o primeiro provoca o estresse do ER e a consequente ativação da via UPR, ao impedir o dobramento de proteínas que dependam da formação de pontes dissulfeto enquanto o segundo estressa o ER impedindo a saída de proteínas já dobradas do lúmen do ER, provocando um aumento de proteínas no lúmen do ER.

Na figura 17, apresentamos um painel com a análise do ciclo celular da Tumoral 1 após a incubação com 5 mM de DTT, agudo ou crônico, e 250 nM de tapsigargina crônico. Pela sua análise, verificou-se que o estresse causado pela incubação com tapsigargina se assemelhou ao que observamos quando as células são estressadas com $5 \mathrm{mM}$ de DTT agudo, onde é visto o acúmulo de células na fase G1 do ciclo celular.

Brewer e colaboradores mostraram que o estresse do ER causado pela tunicamicina e a consequente ativação da via UPR causavam um declínio nos níveis proteicos de ciclina D1 em fibroblastos murinos (40). Essa diminuição de ciclina D1 era responsável pela parada das células na fase G1 do ciclo celular. A repressão da tradução da ciclina D1 após a indução da via UPR era dependente da fosforilação do eIF2 $\alpha$, mas poderia ser independente de PERK $(68,69)$.

Em nosso estudo, a incubação crônica com DTT dos linfócitos B imortalizados gerou uma parada na fase S ou G2 do ciclo celular (figura 12 e tabela 5). 
Figura 17 - Parada das células após a indução da via UPR, é dependente da droga utilizada como estressor.
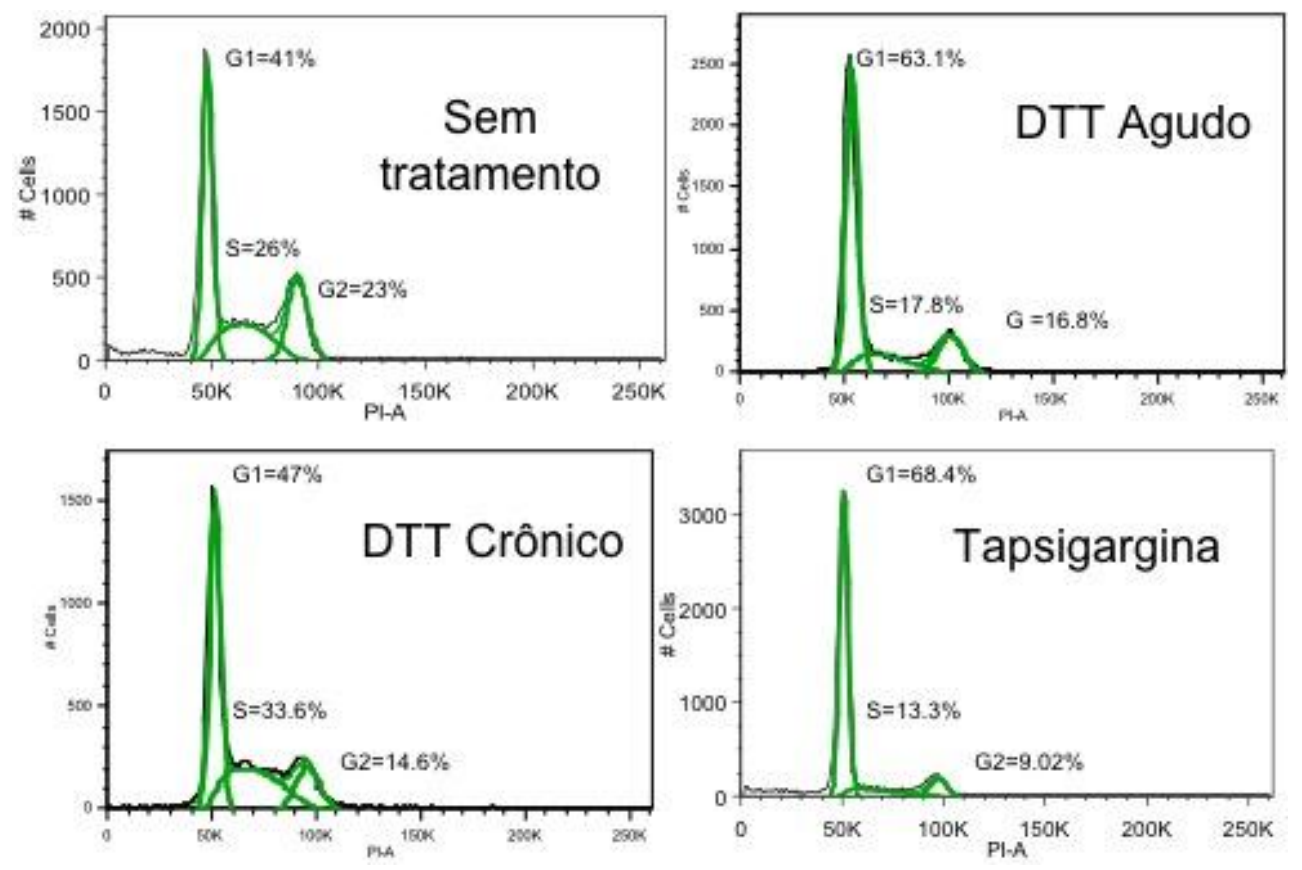

Comparação do ciclo celular após indução com $250 \mathrm{nM}$ de tapsigargina e com DTT. Análise do ciclo celular após o estresse do ER provocado pela incubação com DTT agudo ou crônico ou com tapsigargina por $24 \mathrm{~h}$. As células EBV-B Tumoral 1 foram fixadas e marcadas com PI para a análise de ciclo celular por citometria de fluxo.

É sabido que o DTT e a tapsigargina são as drogas que induzem mais eficientemente o braço da PERK da via UPR. Experimentos realizados com células CHO (Chinese hamster ovary cells) mostraram que a cinética da fosforilação da PERK é mais rápida e eficiente quando o DTT e a tapsigargina são usados como ativadores da via UPR do que com a tunicamicina. No entanto, a cinética de fosforilação do eIF2 $\alpha$, era diferente da cinética de ativação da própria PERK. Isto é, o tratamento das células com DTT induzia apenas um aumento mínimo da fosforilação do eIF2 $\alpha$, apesar de induzir altos níveis de PERK fosforilada. Em contrapartida, o tratamento com tapsigargina produzia a mesma resposta, rápida e intensa, de fosforilação do eIF2 $\alpha$ e de PERK, ou seja, uma cinética de fosforilação em que existia um relação direta. Ainda mais, a fosforilação do eIF2 $\alpha$ após o tratamento com tunicamicina também foi significativa, embora tenha sido menor e mais lenta quando comparada com o tratamento com tapsigargina (88).

Como analisamos anteriormente, em nosso estudo, em linfócitos B imortalizados por EBV, o estresse da via UPR provocado pelo tratamento com DTT induz a parada do ciclo celular em G1 na condição aguda, e em S e G2 na condição crônica. Como 
mencionado anteriormente, o DTT induz de forma eficiente a fosforilação de PERK, mas este aumento de PERK fosforilada não apresenta uma efeito na fosforilação do eIF2 $\alpha$. Neste estudo não analisamos a transcrição de ciclina D1, entretanto mostramos que há um acúmulo dos transcritos de ciclina A1 dependente da ativação da via UPR. Assim, pela literatura e pelos dados por nós obtidos, podemos sugerir que a parada das células em uma fase específica do ciclo celular está relacionada com ativação diferenciada da UPR em decorrência do uso de estressores diferentes. É importante ressaltar que, em nosso estudo, o DTT foi escolhido como estressor do ER por provocar a ativação da via UPR devido ao acúmulo de proteínas não dobradas no lúmen do ER. Essa escolha foi baseada em dados do Paciente $\mathrm{P}$ que apontam para um defeito na ativação da via UPR, que levaria ao não dobramento de imunoglobulinas, causando a hipogamaglobulinemia em um subgrupo de pacientes com CVID.

4.4 Avaliação e comparação do estresse agudo e crônico induzido por DTT na_proliferação celular

Para entender melhor a relação entre ciclo celular, estresse do ER e o problema de proliferação observados nos LB imortalizados do Paciente $\mathrm{P}$, decidimos estudar a proliferação de linfócitos $B$ imortalizados durante ativação da via UPR. Nestes experimentos as células foram marcadas com CFSE ((5(6)-Carboxyfluorescein Nhydroxysuccinimidyl Ester) e depois incubadas na presença ou não de DTT ou nocodazol. O nocodazol é um agente antineoplásico que interfere com a polimerização dos microtúbulos e consequentemente na divisão celular, sendo assim, o ciclo fica parado na fase $\mathrm{G} 2$.

4.4.1 A incubação com $5 \mathrm{mM}$ de DTT induz um atraso na proliferação tanto nos controles quanto nas Tumorais

Na figura 18, observamos os gráficos de MFI (média de intensidade de fluorescência) da proliferação celular dos Controle 3 (CSV) e 4 (CBR) e da Tumoral 1 (Quadro 1). A média de intensidade de fluorescência indica o valor médio de quanto uma célula está expressando determinado marcador. No caso da análise da proliferação, a cada divisão celular observa-se a queda da intensidade de fluorescência do CFSE, uma vez que cada célula-filha terá aproximadamente metade da fluorescência da célula-mãe. Notamos 
nesse experimento que a taxa de proliferação de cada linhagem é diferente. Entretanto, todas as linhagens apresentam um atraso na proliferação após o tratamento com $5 \mathrm{mM}$ de DTT. Este mesmo efeito é observado com o tratamento com nocodazol já que a droga causa a interrupção do ciclo celular na fase G2. No mesmo experimento, também analisamos o ciclo celular e a expressão de genes associados com a via UPR.

Figura 18 - Atraso da proliferação celular provocado pelo estresse induzido pelo tratamento com DTT e nocodazol
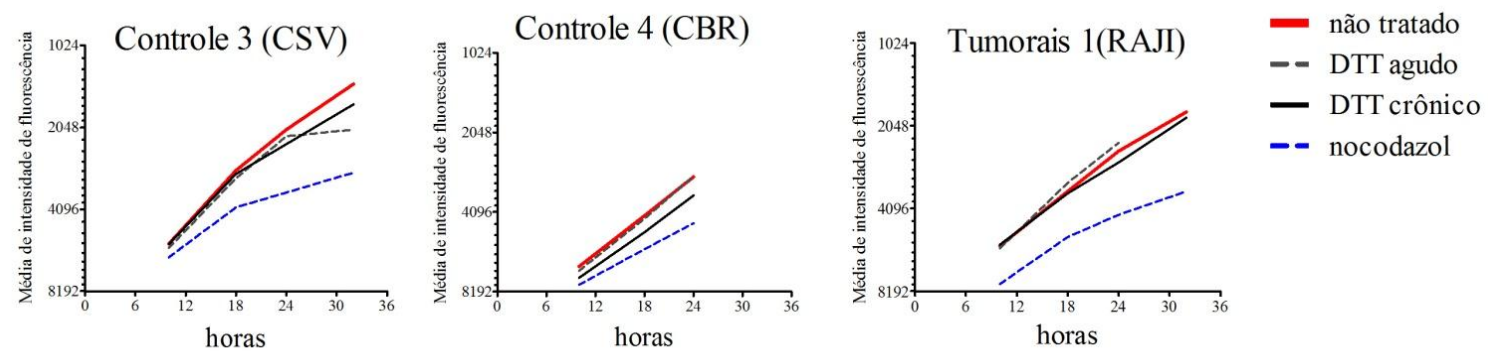

As células foram marcadas com CFSE e depois tratadas com DTT $5 \mathrm{mM}$ agudo ou crônico ou com nocodazol por 10, 18, 24 ou $32 \mathrm{~h}$. Após o término da incubação as células foram analisadas por citometria de fluxo.

Realizamos também as análises do ciclo celular das células Tumoral 1 (Raji) (figura 19). Como vimos nos experimentos anteriores, o tratamento com DTT crônico aumentou a porcentagem de células na fase S (6 h: 17,4\%, 10 h: 22,4\%, 18 h: 32,9 \% e 24 h: 34,9\%). Enquanto que o nocodazol, de acordo com o esperado, foi capaz de provocar um aumento no número de células em G2 ( 6 h: 25,5\%, 10 h: 30,2\%, 18 h: 37,2 \% e 24 h: 64,5\%). 
Figura 19 - Parada do ciclo celular em S após o estresse crônico com DTT e em G2 após o tratamento com nocodazol

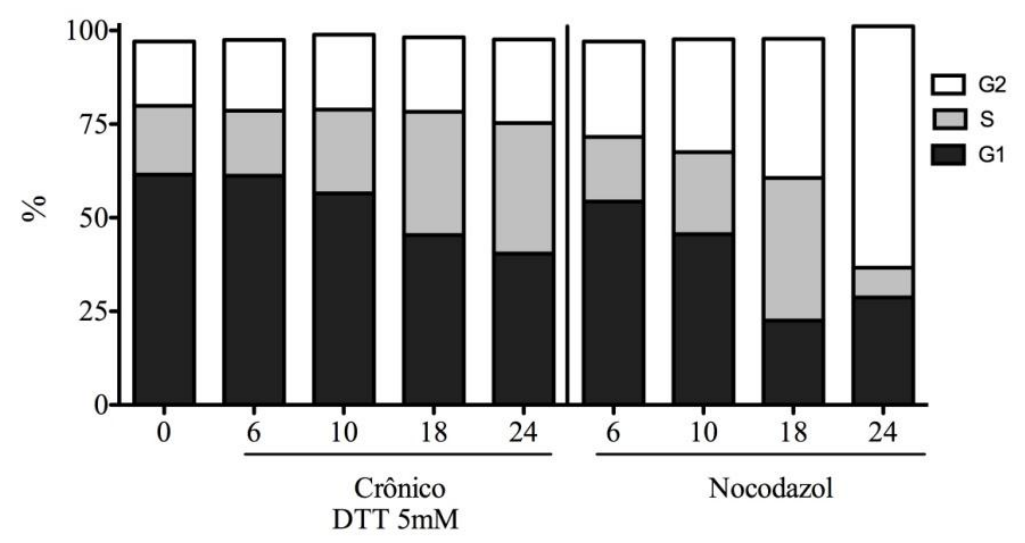

Porcentagem de células em cada fase do ciclo celular após o tratamento com DTT ou nocodazol. As células foram tratadas com DTT $5 \mathrm{mM}$ crônico ou com nocodazol por 6, 10, 18 ou $24 \mathrm{~h}$. Em seguida foram fixadas e marcadas com PI para a análise do ciclo celular por citometria de fluxo.

\subsubsection{A interrupção do ciclo celular não é capaz de ativar a via UPR}

Verificamos que a parada das células em $\mathrm{S}$ ocorreu simultaneamente à ativação crônica da via UPR, que pode ser verificada pelo aumento dos transcritos para BiP, CHOP e GRP94 (figura 20). O aumento dos transcritos de BiP segue o mesmo padrão observado nos experimentos anteriores (figura 8). Quando os linfócitos B são incubados em condições crônicas com $5 \mathrm{mM}$ de DTT, há um aumento dos transcritos de BiP após $6 \mathrm{~h}$, diminuição em $10 \mathrm{~h}$ seguida de um novo aumento após $18 \mathrm{~h}$, sugerindo a ativação persistente da via UPR. Além disso, verificamos o aumento dos transcritos para CHOP com o aumento do tempo de incubação, indicando a ativação do braço da PERK da via UPR.

Podemos observar também o aumento da transcrição de GRP94. A GRP94 é uma chaperona homóloga à proteína HSP90 (Heat Shok protein 90), que geralmente se dimeriza e funciona como uma co-chaperona em um multicomplexo com a chaperona BiP (GRP78) (88). A maior expressão de GRP94 ocorreu após 6 h de tratamento com 5 mM de DTT crônico o que coincide com o pico de transcrição da chaperona BiP.

Assim, os ensaios de proliferação revelaram que o estresse do ER provocado pela incubação aguda e crônica com DTT causa um atraso na proliferação celular, além de ativar a via UPR. Por outro lado o tratamento com nocodazol, que provoca a parada do ciclo celular (figura 19), não foi capaz de ativar a via UPR. 
Figura 20 - A parada das células em G2 provocada pelo nocodazol não ativou a via UPR

Tumoral 1

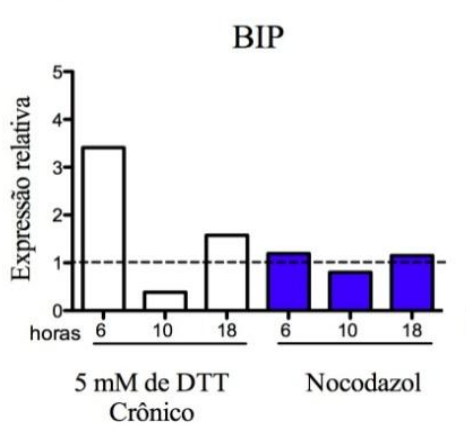

CHOP

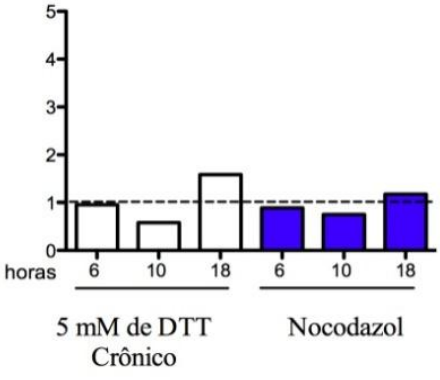

GRP94

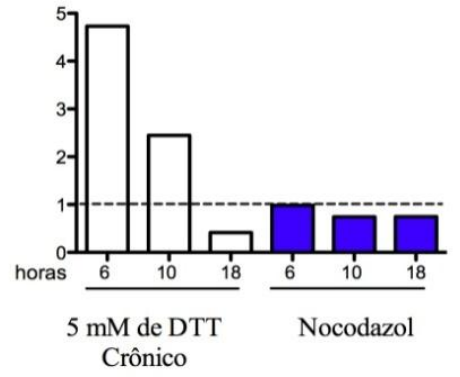

Ativação da via UPR induzida por DTT coincide com a parada das células e S, entretanto a parada das células em G2 provocada pelo nocodazol não ativou a via UPR. Os linfócitos B imortalizados foram incubados por $6,10,18$ ou $24 \mathrm{~h}$ na presença de $5 \mathrm{mM}$ de DTT crônico ou com nocodazol. No gráfico, está representada a expressão relativa pelo método do $2^{-\Delta \Delta \mathrm{Ct}}$.

4.5 Análise da ativação da via UPR e ciclo celular em linfócitos B do Paciente $\mathrm{P}$

As células do Paciente $\mathrm{P}$ foram estressadas com DTT e a ativação da via UPR e as alterações no ciclo celular foram verificadas.

4.5.1 Os linfócitos B imortalizados do Paciente $\mathrm{P}$ apresentam baixa atividade metabólica

Através do ensaio de redução MTT, foi avaliada a atividade metabólica dos linfócitos B imortalizados com EBV do Controle 4 (CBR) e do Paciente P (Figura 21).

A redução do MTT é um método colorimétrico rápido, frequentemente usado para medir proliferação celular e citotoxicidade. Neste ensaio, o MTT é acumulado pelas células por endocitose e a redução do anel tetrazólico deste sal resulta na formação de cristais de formazan de cor azul. Estes se acumulam em compartimentos endossomais e/ou lisossomais, sendo depois transportados para fora das células por exocitose. O ensaio do MTT foi usado como ensaio de viabilidade celular. 
Figura 21 - Atividade metabólica dos linfócitos B imortalizados do Paciente $\mathrm{P}$ e de um controle saudável

Controle

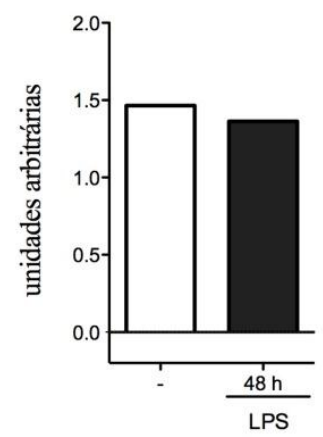

Paciente

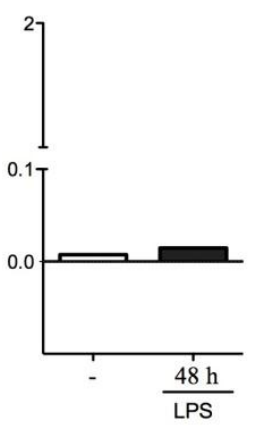

Baixa atividade metabólica dos linfócitos B imortalizados do Paciente P. As células imortalizadas com EBV do Paciente P e de um controle foram tratadas ou não com LPS $10 \mu \mathrm{g} / \mathrm{ml}$ por $48 \mathrm{~h}$. Em seguida, foram incubadas por $4 \mathrm{~h}$ na presença de MTT, lavadas e incubadas sob agitação com solução solubilizadora de MTT. A leitura foi realizada no espectrofotômetro de placa em $570 \mathrm{~nm}$.

Na figura 21, observamos que as células do Paciente $\mathrm{P}$ apresentaram uma atividade metabólica muito baixa em comparação com o controle saudável, sugerindo que estas células não estão proliferando e morrem em cultura. $O$ fato das células crescerem de maneira muito vagarosa dificulta a realização de experimentos com as mesmas.

Outra observação sobre o crescimento destas é que por sua fragilidade, aproximadamente $100 \%$ das células morrem após a centrifugação. Foram realizadas diversas mudanças no protocolo de cultivo dessas células, tais como mudança de meio e de soro fetal bovino, do tipo de pipeta usada durante o repique, e no tipo de placa e de garrafinha. No entanto até o momento não obtivemos sucesso no cultivo dessas células. Novos lotes foram imortalizados mas obtivemos o mesmo resultado insatisfatório.

Tendo em vista as dificuldades do cultivo das células imortalizadas decidimos realizar esses experimentos utilizando linfócitos B obtidos a partir de sangue periférico do Paciente P. Um adicional foi submetido à Comissão de Ética do ICB pedindo a aprovação de uso de sangue periférico de pacientes com CVID, incluindo o Paciente $\mathrm{P}$, para analisarmos a interação do ciclo celular e da via UPR em linfócitos B de sangue periférico.

\subsubsection{Os linfócitos B do Paciente P não ativam a UPR em resposta ao estresse com DTT}

Foram realizadas 3 coletas de sangue durante esse ano. A dificuldade desses 
experimentos foi a quantidade total de linfócitos B obtidos a partir do sangue periférico. Por se tratar de um paciente com imunodeficiência, coletamos no máximo $15 \mathrm{ml}$ de sangue por coleta. Além disso, não possuímos acesso ao paciente todos os meses. Após a separação recuperamos um total de aproximadamente $2,5 \times 10^{6}$ de linfócitos B. A concentração de células purificadas foi então ajustada para $1 \times 10^{6}$ células por ml. Estas células foram incubadas em diferentes condições com $1 \mathrm{mM}$ ou $5 \mathrm{mM}$ de DTT agudo ou crônico, com $10 \mu \mathrm{g} / \mathrm{ml}$ de LPS, com $1,5 \mathrm{mg} / \mathrm{ml}$ de Brefeldina A ou com $250 \mathrm{nM}$ de tapsigargina. Em tempos pré-determinados, foram analisadas quanto à apoptose, e à expressão relativa dos genes BiP, CHOP, EDEM, GRP94 e Ciclina A1

Na Tabela 6, podemos observar a análise de apoptose e necrose realizada através do ensaio de AnexinaV-FITC e Iodeto de Propídeo. É possível verificar um aumento na porcentagem de células apoptóticas após $10 \mathrm{~h}$ de incubação, tanto no ponto sem tratamento (de $1,8 \%$ no $0 \mathrm{~h}$ para $10,8 \%$ no $10 \mathrm{~h}$ ) quanto no ponto tratado com $1 \mathrm{mM}$ de DTT (de 1,8\% para 11,1\%). Entretanto esse aumento da apoptose parece ser decorrente da manipulação e incubação dos linfócitos $\mathrm{B}$, uma vez que não há diferença entre as porcentagens de apoptose das células tratadas e não tratadas.

Tabela 6 - Porcentagem de células apoptóticas e necróticas

\begin{tabular}{cccc}
\hline Horas de incubação & \% Vivas & \% Apoptose & \% Necrose \\
\hline $0 \mathrm{~h}$ & 91,37 & 1,8 & 0,78 \\
$10 \mathrm{~h}$ & 82,7 & 10,8 & 1,71 \\
$10 \mathrm{~h} 1 \mathrm{mM}$ de DTT Agudo & 81,7 & 11,1 & 1,09 \\
\hline
\end{tabular}

Podemos observar um pequeno aumento na expressão relativa dos genes $\mathrm{BiP}$, CHOP e Ciclina A1 após 10 h de incubação no ponto não tratado e no tratado com $1 \mathrm{mM}$ de DTT agudo, porém esse aumento não foi significativo (figura 22). 
Figura 22 - O DTT agudo não induz a ativação da via UPR no paciente $\mathrm{P}$
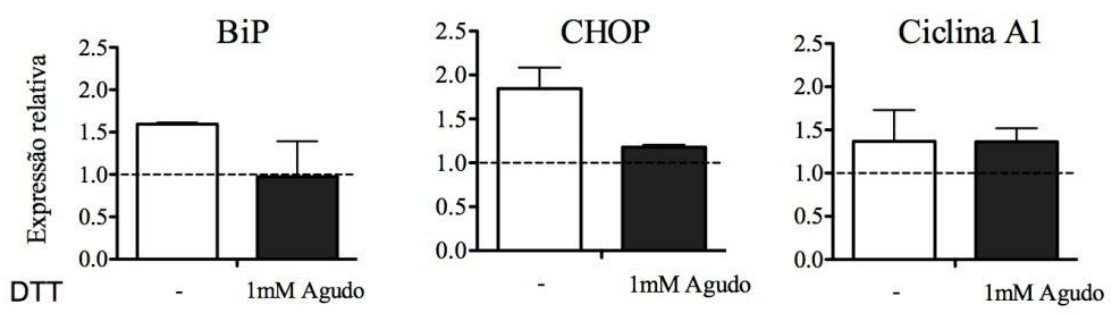

Expressão relativa dos genes BiP, CHOP e Ciclina A1 da coleta 1. Os linfócito B de sangue periférico do Paciente $\mathrm{P}$ foram incubados por $10 \mathrm{~h}$ com $1 \mathrm{mM}$ de DTT agudo. Não houve diferença significativa entre os níveis de transcritos desses três genes entre o ponto $10 \mathrm{~h}$ tratado e o não tratado.

Além disso, este pequeno aumento na transcrição de BiP não foi visto na coleta 2 , na qual os linfócitos B foram tratados com 1 e 5 mM de DTT agudo (Figura 23). Ou seja, o tratamento com DTT agudo não foi capaz de ativar a via UPR dos linfócitos B do Paciente P. É importante lembrar que tanto nos EBV-B dos Controles quanto nos das Tumorais, o tratamento com DTT agudo provoca o aumento dos transcritos BiP após $6 \mathrm{~h}$ de incubação (Figura 8).

Figura 23 - Ativação deficiente da via UPR do Paciente P.
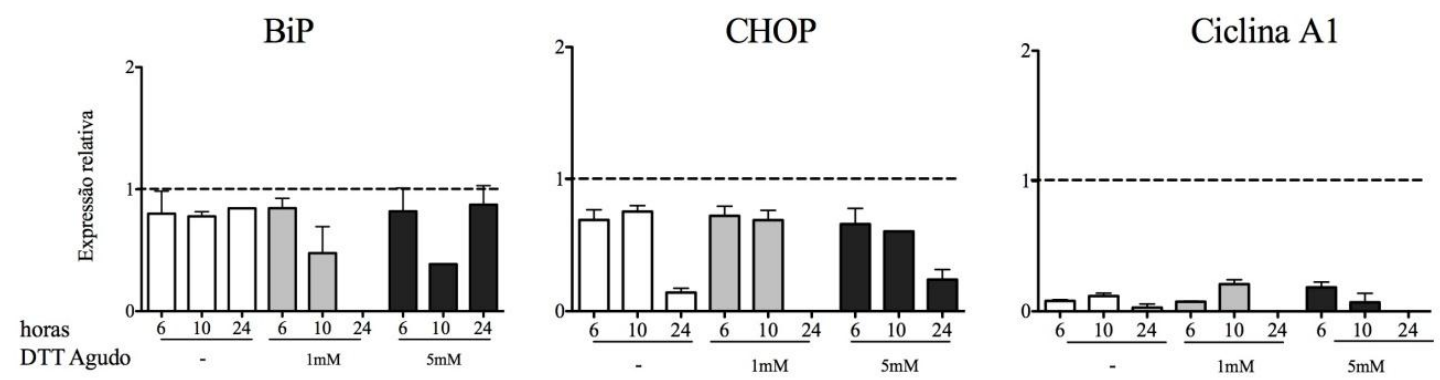

Expressão relativa dos genes BiP, CHOP e Ciclina A1 da coleta 2. O tratamento com 1 ou $5 \mathrm{mM}$ de DTT agudo não ativa a UPR nos LB do Paciente $P$

Estes resultados corroboram os dados anteriormente obtidos pelo laboratório, nos quais se mostrou que o Paciente P apresentava a ativação do eixo IRE1 $\alpha / \mathrm{XBP} 1$ deficiente quando comparado com um controle saudável. Nesse estudo, foi mostrado que o Paciente P apresentava menor expressão da proteína XBP1 spliced em células do sangue periférico ativadas por LPS quando analisado por western-blot. Dada a importância do XBP-1 spliced 
na ativação da maquinaria secretória de imunoglobulinas por plasmócitos, foi postulado que este defeito poderia estar relacionado à hipogamaglobulinemia apresentada pelo paciente. Células do Paciente $\mathrm{P}$ e de um controle saudável foram imortalizadas pelo vírus EBV, estimuladas in vitro com $10 \mu \mathrm{g} / \mathrm{ml}$ LPS por $12 \mathrm{~h}$ e $48 \mathrm{~h}$ e os transcritos de XBP-1 spliced, IRE-1 $\alpha$ e BiP foram determinados por q-PCR. As células do controle saudável estimuladas por LPS apresentaram um pico de transcrição dos genes de interesse em $12 \mathrm{~h}$, seguido de um rápido decréscimo dos transcritos em reflexo da ativação da via UPR e consequente resolução do estresse do ER. Contudo, as células imortalizadas da Paciente P não apresentaram o mesmo pico de transcrição após 12 h de estímulo. Mesmo após 48 h de tratamento com LPS as células deste paciente foram incapazes de atingir a intensidade de expressão gênica alcançada pelas células do controle, em $12 \mathrm{~h}$ de tratamento. Este dado sugere que os linfócitos $\mathrm{B}$ do Paciente $\mathrm{P}$ apresentam uma ativação e uma resolução da via UPR mais lentas em relação ao controle. Foi também analisado a expressão relativa de BiP nas células imortalizadas do Paciente $\mathrm{P}$ e do controle após o tratamento de 8 ou 12 h com Brefeldina A. Após $8 \mathrm{~h}$, as células do Paciente $\mathrm{P}$ e do controle expressaram, respectivamente, 4 e 27 vezes mais $\mathrm{BiP}$ em relação àquelas não tratadas. Doze h após a adição de Brefeldina A à cultura, as células da Paciente $\mathrm{P}$ tiveram uma expressão de BiP 5 vezes maior em relação ao estado basal, enquanto que as células do controle apresentaram uma queda na expressão deste mRNA. Novamente, após $12 \mathrm{~h}$ de tratamento com Brefeldina $\mathrm{A}$, as células do Paciente $\mathrm{P}$ ainda não tinham atingido a intensidade de expressão gênica alcançada pelas células do controle em $8 \mathrm{~h}$ de tratamento. Estes dados nos permitiram postular que os linfócitos $\mathrm{B}$ do Paciente $\mathrm{P}$ apresentam uma ativação e uma resolução da via UPR mais lentas em relação ao controle (59).

Em nosso estudo, os linfócitos B do Paciente P não ativaram a via UPR quando estressados com DTT. A fim de entender se essa ausência de resposta era dependente da droga estressora, decidimos tratar as células com diferentes estressores da via UPR, o DTT crônico, o LPS, a Brefeldina A e a tapsigargina.

$\mathrm{Na}$ figura 24, podemos observar um aumento dos transcritos de BiP, EDEM e GRP94 após o tratamento com com LPS, Brefeldina A e tapsigargina. Sendo que o tratamento com Brefeldina A foi o que provocou maior aumento na expressão relativa de $\operatorname{BiP}(3,7)$. 
Figura 24 - Expressão relativa dos genes BiP, CHOP, EDEM e GRP94 da coleta 3 no paciente $\mathrm{P}$
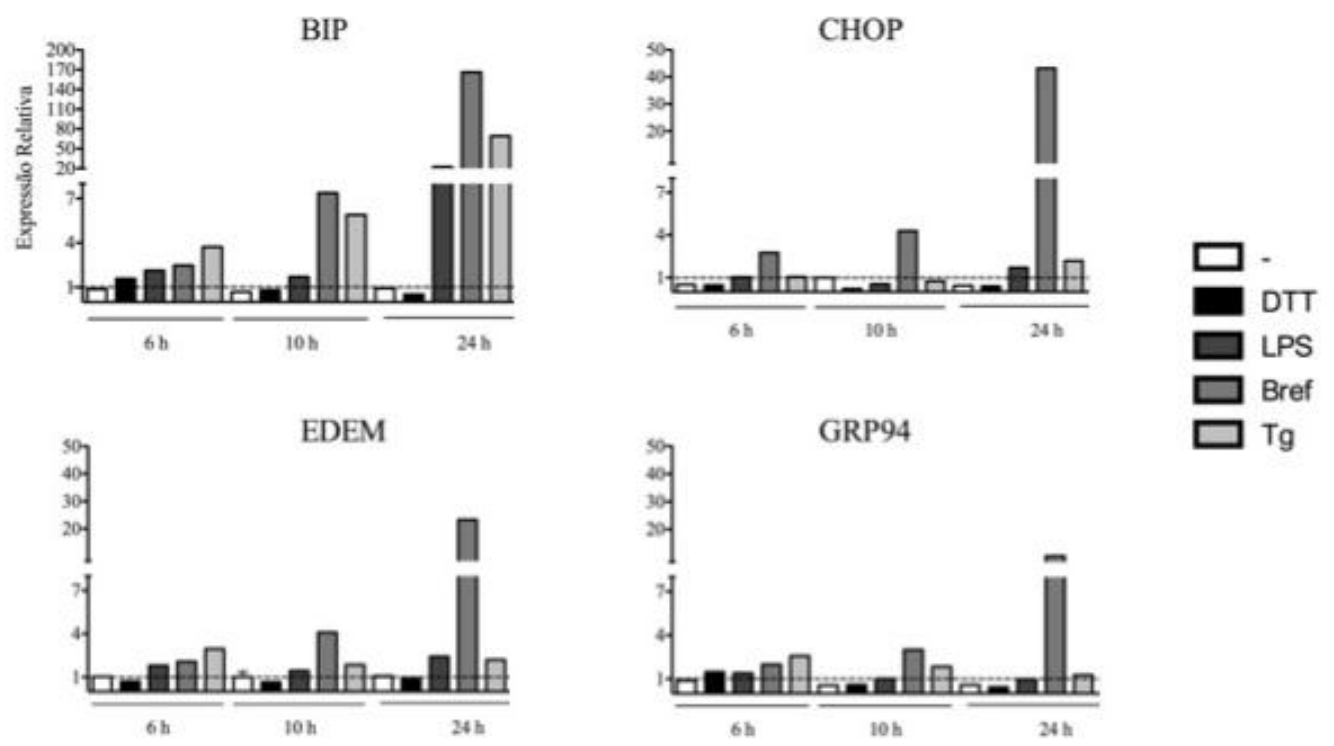

A via UPR do Paciente P é ativada com o tratamento com $10 \mu \mathrm{g} / \mathrm{ml}$ de LPS, 1,5 mg/ml Brefeldina A e $250 \mathrm{nM}$ de Tapsigargina. Os linfócitos B separados a partir de sangue periférico do Paciente $\mathrm{P}$ foram incubados por até $24 \mathrm{~h}$ na presença e ausência de tratamento.

O estresse provocado pela incubação na presença de 1 e $5 \mathrm{mM}$ de DTT na condição aguda não foi capaz de aumentar a expressão de BiP em relação à condição não tratada. No entanto, quando o estresse foi induzido com $5 \mathrm{mM}$ de DTT crônico, observou-se um ligeiro aumento dos transcritos de BiP, EDEM e GRP94. No entanto, quando induzimos o estresse crônico com DTT a expressão relativa de BiP aumenta em média 16 vezes nas células do Controle 2 e nas Tumorais 1 e 2 após 6 h de incubação (figura 8). No caso do Paciente $\mathrm{P}$, esta expressão aumenta 1,5 vezes com $5 \mathrm{mM}$ de DTT crônico e 3,7 vezes quando o estresse é induzido com tapsigargina, a droga que provocou o maior aumento no ponto $6 \mathrm{~h}$.

Já discutimos que a repercussão do tratamento com DTT ou tapsigargina sobre o ciclo celular é diferente. Devemos considerar também a diferença nos mecanismos de ação de cada droga na via UPR. O DTT provoca o estresse do ER e a conseqüente ativação da via UPR, pois impede o dobramento de proteínas que dependam da formação de pontes dissulfeto; a Brefeldina A provoca desarranjo do Complexo de Golgi e transporte retrógrado de proteínas para o retículo endoplasmático. A tapsigargina impede a saída de proteínas já dobradas do lúmen do ER, acarretando o aumento de proteínas precipitadas. Por fim, a ausência de resposta dos linfócitos B do Paciente P após indução do estresse por DTT corrobora o defeito, previamente identificado por nosso grupo, na ativação do braço 
IRE1/XBP1 do Paciente P. É sabido que o principal papel do braço IRE1/XBP1 durante a ativação da via UPR é a depuração de proteínas permanentemente não dobradas (89).

4.5.3 A ausência da ativação da UPR pelo Paciente P após a incubação com DTT não é causado por um dano estrutural

A partir da análise destes resultados, uma explicação para a ausência de resposta dos linfócitos B do Paciente P após indução do estresse por DTT seria o defeito na ativação do braço IRE1/XBP1 do Paciente P, previamente identificado por nosso grupo. Entretanto uma outra explicação para a ausência de resposta do Paciente P frente ao estímulo com DTT seria um dano estrutural dos sensores da via UPR causado por essa droga. Para testar essa hipótese, realizamos um experimento no qual os linfócitos $\mathrm{B}$ do Paciente $\mathrm{P}$ foram cultivados por 24 h na presença simultânea de DTT e LPS além de diferentes indutores da via UPR, tais como apenas o DTT, LPS, Brefeldina A e tapsigargina (figura 25).

Na figura 25, observamos que o tratamento simultâneo com DTT e LPS não alterou os níveis de transcritos de BiP quando comparado com o tratamento feito somente com LPS. Esses resultados sugerem que as diferenças observadas na ativação da UPR refletem diferenças intrínsecas no reconhecimento do estresse pelo linfócito B do Paciente P e não devido a um dano estrutural hipoteticamente provocado pelo DTT. 
Figura 25 - A resposta deficiente do Paciente P frente ao estresse causado pelo DTT não é decorrente de um dano estrutural.
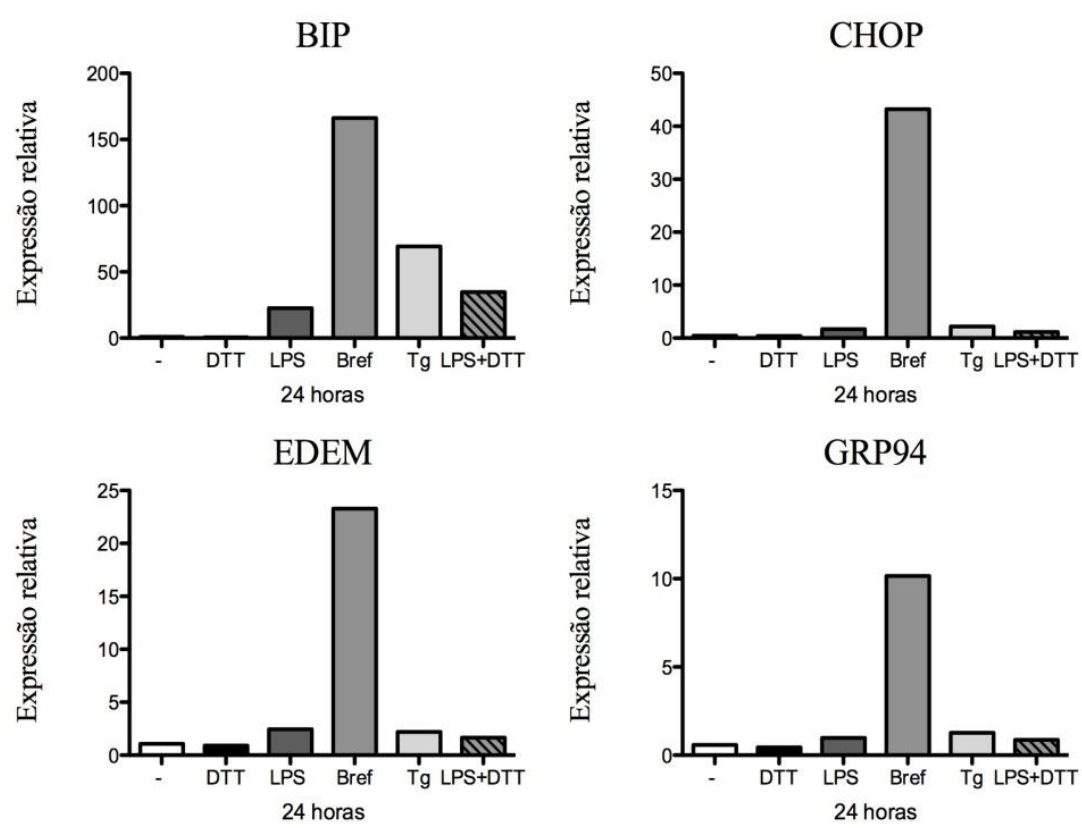

Expressão relativa dos genes BiP, CHOP, EDEM e GRP94 da coleta 3. Os linfócito B do Paciente $\mathrm{P}$ foram cultivados por $24 \mathrm{~h}$ na presença de $5 \mathrm{mM}$ de DTT crônico, LPS, Brefeldina A, tapsigargina e DTT mais LPS

Além disso, essa falha da resposta frente ao estímulo com DTT não foi observada em outras células testadas pelo nosso grupo. Ainda mais, Niwa e colaboradores mostraram que o braço da IRE é capaz de responder eficientemente a diferentes tipos de estresse, como aquele provocado por tunicamicina e tapsigargina, mas é muito mais sensível ao acúmulo de proteínas não dobradas causado pela ruptura das pontes dissulfeto em consequência da incubação com DTT (90).

Portanto, sugerimos que os linfócitos B do Paciente P apresentam uma deficiência maior na resposta frente ao estresse provocado pela incubação com o DTT, possivelmente devido ao defeito observado no braço IRE1/XBP1. 
5 CONCLUSÕES 
Os nossos resultados mostraram que a ativação da via UPR pela incubação com o DTT provoca o acúmulo dos transcritos de ciclina A1 e a parada do ciclo celular. A fase de parada do ciclo celular é dependente da droga estressora e da linhagem celular, corroborando a nossa hipótese de que a ativação da via UPR altera o ciclo celular de maneira estressorespecífica. No entanto, o contrário não se mostrou verdadeiro, a parada no ciclo celular provocada por nocodazol não ativou a via UPR. A alteração do ciclo celular provocada pela ativação da via UPR está correlacionada com o acúmulo dos transcritos de ciclina A1 e a interrupção da natureza cíclica dessa proteína.

Em relação aos experimentos realizados com os linfócitos B do Paciente P, observouse que a via UPR do Paciente P não é ativada em resposta ao DTT, mas sim em resposta a outros estressores conhecidos do ER como a tapsigargina, brefeldina A e o LPS. Uma vez que o DTT não causa nenhum dano estrutural nos sensores do ER este resultado sugere que defeito no braço da IRE1 $\alpha$, verificado no Paciente P, impede à ativação da UPR causada pelo DTT. 
REFERÊNCIAS 


\section{REFERÊNCIAS*}

1. Simon SM, Peskin CS, Oster GF. What drives the translocation of proteins? Proc Natl Acad Sci U S A. 1992;89(9):3770-4.

2. Gilmore R. Protein translocation across the endoplasmic reticulum: a tunnel with toll booths at entry and exit. Cell. 1993;75(4):589-92.

3. Simon SM, Aderem A. Myristoylation of proteins in the yeast secretory pathway. J Biol Chem. 1992;267(6):3922-31.

4. Otero JH, Lizak B, Hendershot LM. Life and death of a BiP substrate. Semin Cell Dev Biol. 2010;21(5):472-8.

5. Aebi M, Bernasconi R, Clerc S, Molinari M. N-glycan structures: recognition and processing in the ER. Trends Biochem Sci. 2010;35(2):74-82.

6. Ellgaard L, Helenius A, Quality control in the endoplasmic reticulum. Nat Rev Mol Cell Biol. 2003;4:181-191

7. Lajoie P, Snapp EL. Changes in BiP availability reveal hypersensitivity to acute endoplasmic reticulum stress in cells expressing mutant huntingtin. J Cell Sci. 2011;124(Pt 19):3332-43.

8. Liu Y, Lee SY, Neely E, Nandar W, Moyo M, Simmons Z, et al. Mutant HFE H63D protein is associated with prolonged endoplasmic reticulum stress and increased neuronal vulnerability. J Biol Chem. 2011;286(15):13161-70.

9. Bartoszewski R, Rab A, Fu L, Bartoszewska S, Collawn J, Bebok Z. CFTR expression regulation by the unfolded protein response. Methods Enzymol. 2011;491:3-24.

10. Mitchell CA, Beall JA, Wells JR, Gray PP. Growth and protein production kinetics of a murine myeloma cell line transfected with the human growth hormone gene. Cytotechnology. 1991;5(3):223-31.

11. Werner ED, Brodsky JL, McCracken AA. Proteasome-dependent endoplasmic reticulum-associated protein degradation: an unconventional route to a familiar fate. Proc Natl Acad Sci U S A. 1996;93(24):13797-801.

12. Harding HP, Zhang Y, Ron D. Protein translation and folding are coupled by an endoplasmic-reticulum-resident kinase. Nature. 1999;397(6716):271-4.

13. Harding HP, Calfon M, Urano F, Novoa I, Ron D. Transcriptional and translational control in the Mammalian unfolded protein response. Annu Rev Cell Dev Biol. 2002;18:57599.

\footnotetext{
* De acordo com:

International Committee of Medical Journal Editors. [Internet]. Uniform requirements for manuscripts submitted to Biomedical Journal: sample references. [updated 2011Jul 15]. Available from: http://www.icmje.org
} 
14. Shamu CE. Splicing together the unfolded-protein response. Curr Biol. 1997;7(2):R67-70.

15. Hendershot LM, Ting J, Lee AS. Identity of the immunoglobulin heavy-chain-binding protein with the 78,000-dalton glucose-regulated protein and the role of posttranslational modifications in its binding function. Mol Cell Biol. 1988;8(10):4250-6.

16. Schroder M, Kaufman RJ. The mammalian unfolded protein response. Annu Rev Biochem.2005;74:739-789

17. Ritter C, Helenius A. Recognition of local glycoprotein misfolding by the ER folding sensor UDP-glucose:glycoprotein glucosyltransferase. Nat Struct Biol. 2000;7(4):278-80.

18. Glembotski CC. The role of the unfolded protein response in the heart. J Mol Cell Cardiol. 2008;44(3):453-9.

19. Tardif KD, Mori K, Siddiqui A. Hepatitis C virus subgenomic replicons induce endoplasmic reticulum stress activating an intracellular signaling pathway. J Virol. 2002;76(15):7453-9.

20. Ryu JC, Kim YJ, Chai YG. Mutation spectrum of 1,2-dibromo-3-chloropropane, an endocrine disruptor, in the lacI transgenic Big Blue Rat2 fibroblast cell line. Mutagenesis. 2002;17(4):301-7.

21. Reimold AM, Iwakoshi NN, Manis J, Vallabhajosyula P, Szomolanyi-Tsuda E, Gravallese EM, et al. Plasma cell differentiation requires the transcription factor XBP-1. Nature. 2001;412(6844):300-7.

22. Rutkowski DT, Kaufman RJ. A trip to the ER: coping with stress. Trends Cell Biol. 2004;14(1):20-8.

23. Bertolotti A, Zhang Y, Hendershot LM, Harding HP, Ron D. Dynamic interaction of BiP and ER stress transducers in the unfolded-protein response. Nat Cell Biol. 2000;2(6):32632.

24. Costa CZ, da Rosa SE, de Camargo MM. The unfolded protein response: how protein folding became a restrictive aspect foi innate immunity and B lymphocytes. Scand $\mathbf{J}$ Immunol. 2001;73(5) 436-48.

25. Hendershot LM. The ER function BiP is a master regulator of ER function. Mt Sinai J Med. 2004;71(5):289-97.

26. Kimata Y, Oikawa D, Shimizu Y, Ishiwata-Kimata Y, Kohno K. A role for BiP as an adjustor for the endoplasmic reticulum stress-sensing protein Ire1. $J$ Cell Biol. 2004;167(3):445-56

27. Haze K, Yoshida H, Yanagi H, Yura T, Mori K. Mammalian transcription factor ATF6 is synthesized as a transmembrane protein and activated by proteolysis in response to endoplasmic reticulum stress. Mol Biol Cell. 1999;10(11):3787-99 
28. Kaufman RJ. Stress signaling from the lumen of the endoplasmic reticulum: coordination of gene transcriptional and translational controls. Genes Dev. 1999;13(10):121133.

29. Tirasophon W, Lee K, Callaghan B, Welihinda A, Kaufman RJ. The endoribonuclease activity of mammalian IRE1 autoregulates its mRNA and is required for the unfolded protein response. Genes Dev. 2000;14(21):2725-36.

30. Niwa M, Sidrauski C, Kaufman RJ, Walter P. A role for presenilin-1 in nuclear accumulation of Ire 1 fragments and induction of the mammalian unfolded protein response. Cell. 1999;99(7):691-702.

31. Yoshida H, Matsui, T., Yamamoto, A., Okada, T., Mori, K. XBP1 mRNA is induced by ATF6 and spliced by IRE1 in response to ER stress to produce a highly active transcription factor. Cell. 2001;107(7):881-91.

32. Oda Y, Hosokawa N, Wada I, Nagata K. EDEM as an acceptor of terminally misfolded glycoproteins released from calnexin. Science. 2003;299(5611):1394-7.

33. Nakagawa T, Zhu H, Morishima N, Li E, Xu J, Yankner BA, et al. Caspase-12 mediates endoplasmic-reticulum-specific apoptosis and cytotoxicity by amyloid-beta. Nature. 2000;403(6765):98-103.

34. Urano F, Wang X, Bertolotti A, Zhang Y, Chung P, Harding HP, et al. Coupling of stress in the ER to activation of JNK protein kinases by transmembrane protein kinase IRE1. Science. 2000;287(5453):664-6.

35. Ye J, Rawson RB, Komuro R, Chen X, Dave UP, Prywes R, et al. ER stress induces cleavage of membrane-bound ATF6 by the same proteases that process SREBPs. Mol Cell. 2000;6(6):1355-64.

36. Shen X, Ellis RE, Lee K, Liu CY, Yang K, Solomon A, et al. Complementary signaling pathways regulate the unfolded protein response and are required for $\mathrm{C}$. elegans development. Cell. 2001;107(7):893-903.

37. Scheuner D, Song B, McEwen E, Liu C, Laybutt R, Gillespie P, et al. Translational control is required for the unfolded protein response and in vivo glucose homeostasis. Mol Cell. 2001;7(6):1165-76.

38. Harding HP, Novoa I, Zhang Y, Zeng H, Wek R, Schapira M, et al. Regulated translation initiation controls stress-induced gene expression in mammalian cells. Mol Cell. 2000;6(5):1099-108.

39. Harding HP, Novoa I, Zhang Y, Zeng H, Wek R, Schapira M, et al. Regulated translation initiation controls stress-induced gene expression in mammalian cells. Mol Cell. 2000;6(5):1099-108.

40. Brewer JW, Hendershot LM, Sherr CJ, Diehl JA. Mammalian unfolded protein response inhibits cyclin D1 translation and cell-cycle progression. Proc Natl Acad Sci U S A. 1999;96(15):8505-10. 
41. You KR, Liu MJ, Lee ZW, Kim DG. Transcriptional regulation of the humam transferrin gene by GADD153 in hepatoma cells. Hepatolygy . 2003; 38:745-755

42. Boyce M, Yuan J. Cellular response to endoplasmic reticulum stress: a matter of life or death. Cell Death Differ. 2006;13(3):363-73.

43. Novoa I, Zhang Y, Zeng H, Jungreis R, Harding HP, Ron D. Stress-induced gene expression requires programmed recovery from translational repression. EMBO J. 2003;22(5):1180-7.

44. Chaudhary PM, Eby M, Jasmin A, Bookwalter A, Murray J, Hood L. Death receptor 5, a new member of the TNFR family, and DR4 induce FADD-dependent apoptosis and activate the NF-kappaB pathway. Immunity. 1997;7(6):821-30.

45. Daniel NN, Korsmeyer SJ. Cell death: critical control points. Cell. 2004; 116:205-219

46. Barone MV, Crozat A, Tabaee A, Philipson L, Ron D. CHOP (GADD153) and its oncogenic variant, TLS-CHOP, have opposing effects on the induction of G1/S arrest. Genes Dev. 1994;8(4):453-64.

47. Zinszner H, Kuroda M, Wang X, Batchvarova N, Lightfoot RT, Remotti H, et al. CHOP is implicated in programmed cell death in response to impaired function of the endoplasmic reticulum. Genes Dev. 1998;12(7):982-95.

48. Amundson SA, Myers TG, Fornace AJ, Jr. Roles for p53 in growth arrest and apoptosis: putting on the brakes after genotoxic stress. Oncogene. 1998;17(25):3287-99.

49. Yoshida H, Okada T, Haze K, Yanagi H, Yura T, Negishi M, et al. ATF6 activated by proteolysis binds in the presence of NF-Y (CBF) directly to the cis-acting element responsible for the mammalian unfolded protein response. Mol Cell Biol. 2000;20(18):6755-67.

50. Lee K, Tirasophon W, Shen X, Michalak M, Prywes R, Okada T, et al. IRE1-mediated unconventional mRNA splicing and S2P-mediated ATF6 cleavage merge to regulate XBP1 in signaling the unfolded protein response. Genes Dev. 2002;16(4):452-66.

51. Lee AH, Iwakoshi NN, Glimcher LH. XBP-1 regulates a subset of endoplasmic reticulum resident chaperone genes in the unfolded protein response. Mol Cell Biol. 2003;23(21):7448-59.

52. Calfon M, Zeng H, Urano F, Till JH, Hubbard SR, Harding HP, et al. IRE1 couples endoplasmic reticulum load to secretory capacity by processing the XBP-1 mRNA. Nature. 2002;415(6867):92-6.

53. Yamamoto K, Sato T, Matsui T, Sato M, Okada T, Yoshida H, et al. Transcriptional induction of mammalian ER quality control proteins is mediated by single or combined action of ATF6alpha and XBP1. Dev Cell. 2007;13(3):365-76.

54. Iwakoshi NN, Lee AH, Vallabhajosyula P, Otipoby KL, Rajewsky K, Glimcher LH. Plasma cell differentiation and the unfolded protein response intersect at the transcription factor XBP-1. Nat Immunol. 2003;4(4):321-9. 
55. Sckalet AH, Isler JA, King LB, Harding HP, Ron D, Monroe JG. Rapid B cell receptor-induced unfolded protein response in nonsecretory $\mathrm{B}$ cells correlates with pro-versus antiapoptotic cell fate. J Biol Chem. 2005; 280(48): 39762-71.

56. Notarangelo LD. Primary immunodeficiencies (PIDs) presenting with cytopenias. Hematology Am Soc Hematol Educ Program. 2009:139-43.

57. Janeway CA, Apt L and Gitlin D. Agammaglobulinemia. 1953. Trans Assoc Am Phys 66: 200-204.

58. Lu W, Liu ZY, Li TS. [Common variable immunodeficiency: report of 12 cases and review of literature]. Zhonghua Nei Ke Za Zhi. 2008;47(5):378-81.

59. Kuribayashi JS, Bombardieri CR, Baracho GV, Aliberti J, Machado FS, Kalil J, et al. Slower rescue of ER homeostasis by the unfolded protein response pathway associated with common variable immunodeficiency. Mol Immunol. 2008;45(10):2990-7.

60 Kuribayashi, Juliana Sayuri. A desregulação da via UPR associada à imunodeficiência comum variável. Dissertação de Mestardo- Universidade de São Paulo. 2007

61. Guo BC, Saxon A. B cell lines from a subset of patients with common variable immunodeficiency undergo enhanced apoptosis associated with an increased display of CD95 (Apo-1/fas), diminished CD38 expression, and decreased IgG and IgA production. Cell Immunol. 1995;166(1):83-92.

62. Heichman KA, Roberts JM. Rules to replicate by. Cell. 1994;79(4):557-62.

63. Matsushime H, Ewen ME, Strom DK, Kato JY, Hanks SK, Roussel MF, et al. Identification and properties of an atypical catalytic subunit (p34PSK-J3/cdk4) for mammalian D type G1 cyclins. Cell. 1992;71(2):323-34.

64. Marcote MJ, Pagano M, Draetta G. cdc2 protein kinase: structure-function relationships. Ciba Found Symp. 1992;170:30-41; discussion -9.

65. Hochegger H, Takeda S, Hunt T. Cyclin-dependent kinases and cell-cycle transitions: does one fit all? Nat Rev Mol Cell Biol. 2008;9(11):910-6.

66. Hochegger H, Takeda S, Hunt T. Cyclin-dependent kinases and cell-cycle transitions: does one fit all? Nat Rev Mol Cell Biol. 2008;9(11):910-6

67. Ghosh TK, Bian JH, Short AD, Rybak SL, Gill DL. Persistent intracellular calcium pool depletion by thapsigargin and its influence on cell growth. $J$ Biol Chem. 1991;266(36):24690-7..

68. Eriksen SH, Jensen B, Olsen J. Effect of N-linked glycosylation on secretion, activity, and stability of alpha-amylase from Aspergillus oryzae. Curr Microbiol. 1998;37(2):117-22.

69. Brewer JW, Diehl JA. PERK mediates cell-cycle exit during the mammalian unfolded protein response. Proc Natl Acad Sci U S A. 2000;97(23):12625-30. 
70. Hamanaka RB, Bennett BS, Cullinan SB, Diehl JA. PERK and GCN2 contribute to eIF2alpha phosphorylation and cell cycle arrest after activation of the unfolded protein response pathway. Mol Biol Cell. 2005;16(12):5493-501.

71. Raven JF, Baltzis D, Wang S, Mounir Z, Papadakis AI, Gao HQ, et al. PKR and PKRlike endoplasmic reticulum kinase induce the proteasome-dependent degradation of cyclin D1 via a mechanism requiring eukaryotic initiation factor 2 alpha phosphorylation. J Biol Chem. 2008;283(6):3097-108.

72. Thorpe JA, Schwarze SR. IRE1alpha controls cyclin A1 expression and promotes cell proliferation through XBP-1. Cell Stress Chaperones. 2010;15(5):497-508.

73. Pagano M, Pepperkok R, Verde F, Ansorge W, Draetta G. Cyclin A is required at two points in the human cell cycle. EMBO J. 1992;11(3):961-71.

74. Yang R, Morosetti R, Koeffler HP. Characterization of a second human cyclin A that is highly expressed in testis and in several leukemic cell lines. Cancer Res. 1997;57(5):91320 .

75. Li X, Zhu H, Huang H, Jiang R, Zhao W, Liu Y, et al. Study on the effect of IRE1a on cell growth and apoptosis via modulation PLK1 in ER stress response. Mol Cell Biochem. 2012;365(1-2):99-108.

76. Livak KJ, Schmittgen TD. Analysis of relative gene expression data using real-time quantitative PCR and the 2(-Delta Delta C(T)) Method. Methods. 2001; 25(4):402-8.

77. Berridge MJ. Inositol triphosphate and calcuim signalling.Nature. 1993; 361:315-325.

78. Healy SJ, Gorman AM, Mousavi-Shafaei P, Gupta S, Samali A. Targeting the endoplasmic reticulum-stress response as an anticancer strategy. Eur $\mathbf{J}$ Pharmacol. 2009;625(1-3):234-46.

79. Bagratuni T, Wu P, Gonzalez de Castro D, Davenport EL, Dickens NJ, Walker BA, et al. XBP1s levels are implicated in the biology and outcome of myeloma mediating different clinical outcomes to thalidomide-based treatments. Blood. 2010;116(2):250-3.

80. Zhang J, Jiang Y, Jia Z, Li Q, Gong W, Wang L, et al. Association of elevated GRP78 expression with increased lymph node metastasis and poor prognosis in patients with gastric cancer. Clin Exp Metastasis. 2006;23(7-8):401-10.

81. Li J, Lee AS. Stress induction of GRP78/BiP and its role in cancer. Curr Mol Med. 2006;6(1):45-54.

82. Lee E, Nichols P, Spicer D, Groshen S, Yu MC, Lee AS. GRP78 as a novel predictor of responsiveness to chemotherapy in breast cancer. Cancer Res. 2006;66(16):7849-53. Epub.

83. Gass JN, Gifford NM, Brewer JW. Activation of an unfolded protein response during differentiation of antibody-secreting B cells. J Biol Chem. 2002;277(50):49047-54.. 
84. Ma Y, Shimizu Y, Mann MJ, Jin Y, Hendershot LM. Plasma cell differentiation initiates a limited ER stress response by specifically suppressing the PERK-dependent branch of the unfolded protein response. Cell Stress Chaperones. 2010;15(3):281-93.

85. Kuppers R. B cells under influence: transformation of B cells by Epstein-Barr virus. Nat Rev Immunol. 2003;3(10):801-12.

86. Lam N, Sandberg ML, Sugden B. High physiological levels of LMP1 result in phosphorylation of eIF2 alpha in Epstein-Barr virus-infected cells. J Virol. 2004;78(4):165764.

87. Lee DY, Sugden B. The LMP1 oncogene of EBV activates PERK and the unfolded protein response to drive its own synthesis. Blood. 2008;111(4):2280-9.

88. Melnick J, Aviel S, Argon Y. The endoplasmic reticulum stress protein GRP94, in addition to $\mathrm{BiP}$, associates with unassembled immunoglobulin chains. J Biol Chem. 1992;267(30):21303-6.

89. Yoshida H, Matsui T, Hosokawa N, Kaufman RJ, Nagata K, Mori K. A timedependent phase shift in the mammalian unfolded protein response. Dev Cell. 2003;4(2):26571.

90. Jenney B Durose, Arvin B T, Niwa M. Instrinsic capacities of molecular sensors of the unfolded protein response to sense alterante forms of endoplasmic reticulum stress. Mol Biol Cell. 2006; 17(7)3095-3107 
APÊNDICES 
APÊNDICE A - Padronização da análise do ciclo celular

Figura A.1 - Análise do ciclo celular por citometria de fluxo utilizando PI e fixação por etanol

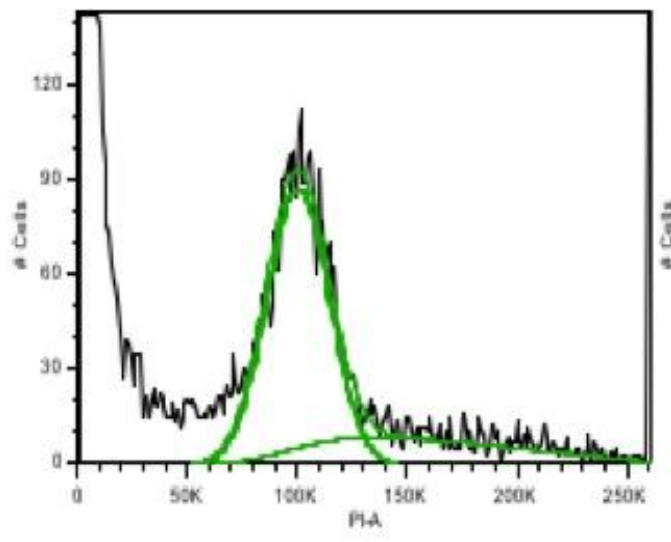

Hidroxiuréia $0,1 \mathrm{M}$

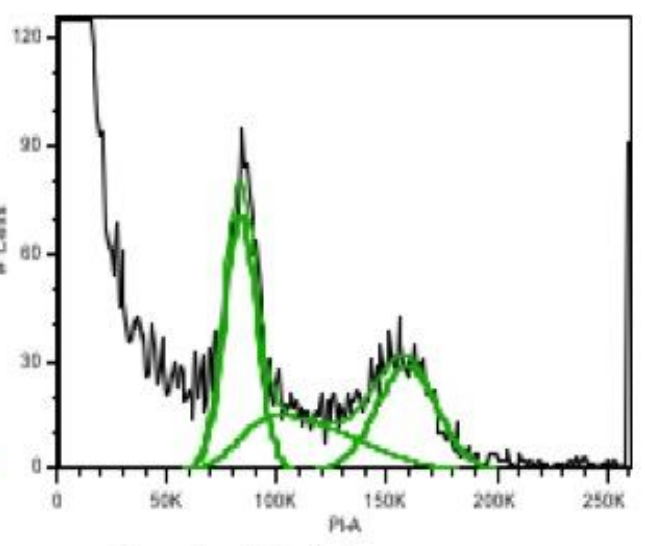

Nocodazol $2 \mu \mathrm{g} / \mathrm{ml}$

Linfócitos B imortalizados com EBV foram incubados por $48 \mathrm{~h}$ na presença de Nocodazol e Hidroxiuréia e depois marcadas para análise de ciclo celular. 
APÊNDICE B - Titulação do estresse com DTT

Tabela B.1 - Porcentagem de células mortas após a incubação com DTT

\begin{tabular}{cccc}
\hline & Dose de DTT & \% vivas & \% mortas \\
\hline Sem Tratamento & - & 82 & 18 \\
Agudo & 0,05 & 78 & 22 \\
& 0,5 & 80 & 19 \\
& 5 & 81 & 19 \\
Crônico & 10 & 69 & 30 \\
& 0,05 & 82 & 18 \\
& 0,5 & 83 & 16 \\
& 5 & 34 & 66 \\
\hline
\end{tabular}


APÊNDICE C - Comparação do estresse agudo e crônico com 5 mM de DTT

Tabela C.1 - Porcentagem de células mortas no Controle 1:

\begin{tabular}{cccc}
\hline Tratamento & Tempo & \% Vivas & \% Mortas \\
\hline \multirow{2}{*}{ Sem tratamento } & $0 \mathrm{~h}$ & 63 & 31 \\
& $6 \mathrm{~h}$ & 71 & 23 \\
& $10 \mathrm{~h}$ & 67 & 27 \\
& $24 \mathrm{~h}$ & 62 & 21 \\
Agudo & $6 \mathrm{~h}$ & 68 & 19 \\
& $10 \mathrm{~h}$ & 71 & 16 \\
\multirow{3}{*}{ Crônico } & $24 \mathrm{~h}$ & 65 & 23 \\
& $6 \mathrm{~h}$ & 68 & 14 \\
& $10 \mathrm{~h}$ & 67 & 16 \\
\hline
\end{tabular}

Tabela C.2 - Porcentagem de células mortas no Controle 2:

\begin{tabular}{cccc}
\hline Tratamento & Tempo & \% Vivas & \% Mortas \\
\hline \multirow{2}{*}{ Sem tratamento } & $0 \mathrm{~h}$ & 71 & 27 \\
& $6 \mathrm{~h}$ & 80 & 19 \\
& $10 \mathrm{~h}$ & 74 & 24 \\
& $24 \mathrm{~h}$ & 77 & 22 \\
Agudo & $6 \mathrm{~h}$ & 76 & 23 \\
& $10 \mathrm{~h}$ & 70 & 29 \\
\multirow{3}{*}{ Crônico } & $24 \mathrm{~h}$ & 74 & 25 \\
& $6 \mathrm{~h}$ & 65 & 34 \\
& $10 \mathrm{~h}$ & 19 & 80 \\
\hline
\end{tabular}


Tabela C.3 - Porcentagem de células mortas no Tumoral 1:

\begin{tabular}{cccc}
\hline Tratamento & Tempo & \% Vivas & \% Mortas \\
\hline \multirow{2}{*}{ Sem tratamento } & $0 \mathrm{~h}$ & 97 & 3 \\
& $6 \mathrm{~h}$ & 97 & 2 \\
& $10 \mathrm{~h}$ & 96 & 4 \\
& $24 \mathrm{~h}$ & 97 & 2 \\
Agudo & $6 \mathrm{~h}$ & 96 & 3 \\
& $10 \mathrm{~h}$ & 96 & 3 \\
\multirow{3}{*}{ Crônico } & $24 \mathrm{~h}$ & 96 & 3 \\
& $6 \mathrm{~h}$ & 95 & 4 \\
& $10 \mathrm{~h}$ & 95 & 4 \\
\hline
\end{tabular}

Tabela C.4 - Porcentagem de células mortas no Tumoral 2:

\begin{tabular}{cccc}
\hline Tratamento & Tempo & \% Vivas & \% Mortas \\
\hline \multirow{2}{*}{ Sem tratamento } & $0 \mathrm{~h}$ & 96 & 3 \\
& $6 \mathrm{~h}$ & 97 & 2 \\
& $10 \mathrm{~h}$ & 95 & 4 \\
& $24 \mathrm{~h}$ & 95 & 4 \\
Agudo & $6 \mathrm{~h}$ & 96 & 3 \\
& $10 \mathrm{~h}$ & 96 & 4 \\
\multirow{3}{*}{ Crônico } & $24 \mathrm{~h}$ & 96 & 3 \\
& $6 \mathrm{~h}$ & 96 & 4 \\
& $10 \mathrm{~h}$ & 94 & 5 \\
\hline
\end{tabular}


Figura C.1 - Quantificação do splicing do XBP1 após a indução do estresse por DTT no Controle 1

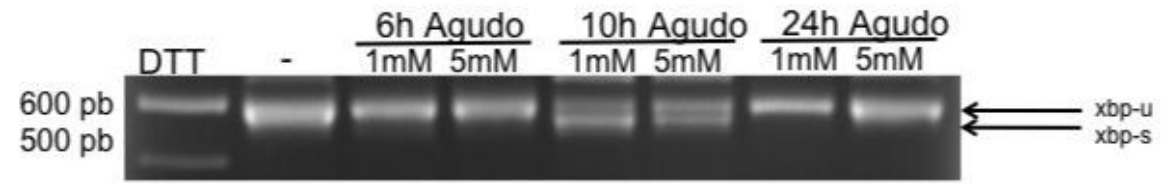

Presença da banda do XBP1s inicia-se apos $6 \mathrm{~h}$ de incubação mas o pico ocorre apos $10 \mathrm{~h}$ Linfócitos B imortalizados do controle Piedade, foram incubados por 6, 10 ou 24h na presença ou ausência de 1 ou $5 \mathrm{mM}$ de DTT agudo.

Figura C.2 - Análise do ciclo celular após o tratamento agudo com 5 mM de DTT

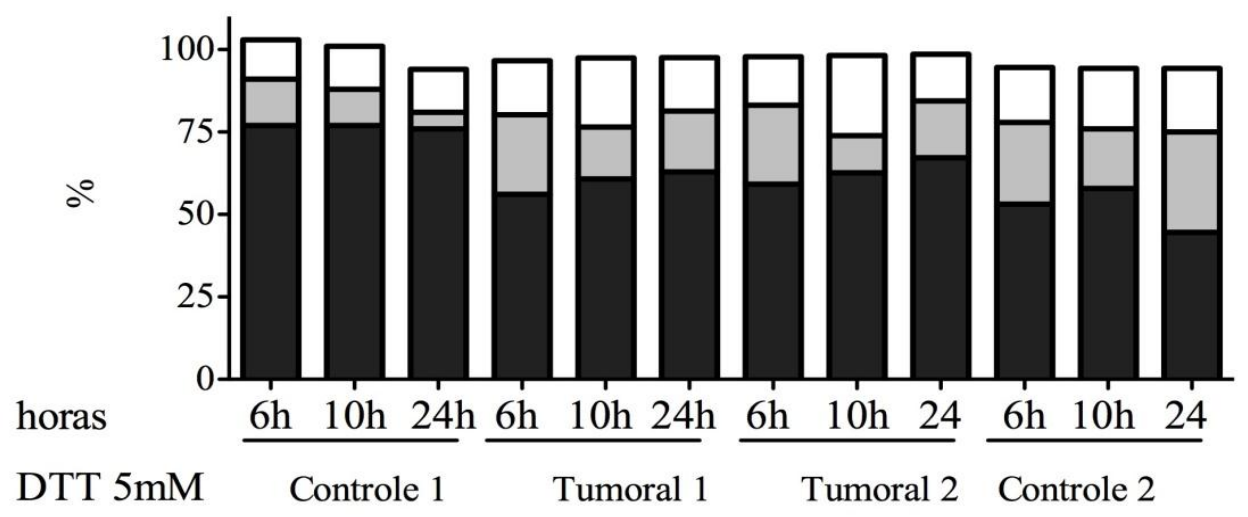

Linfócitos B imortalizados do controles 1 e 2 e das tumorais 1 e 2, foram incubados por 6, 10 ou $24 \mathrm{~h}$ na presença ou ausência de $5 \mathrm{mM}$ de DTT. As amostras foram analisadas quanto a fase do ciclo celular, por citometria de fluxo

Figura C.3 - Análise do ciclo celular após o tratamento crônico com 5 mM de DTT

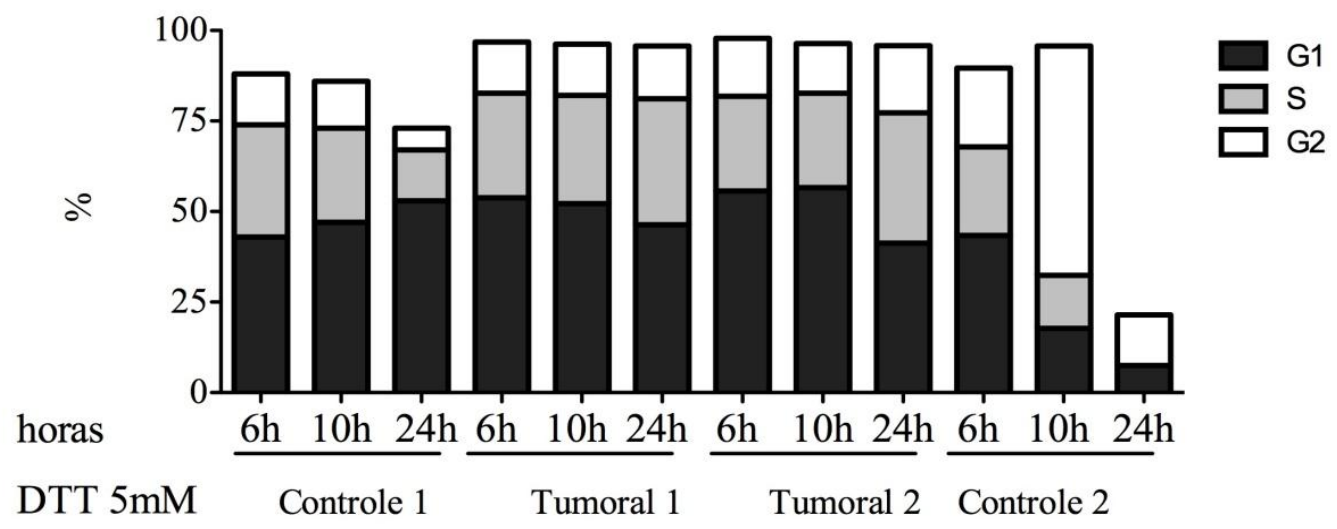

Linfócitos B imortalizados do controles 1 e 2 e das tumorais 1 e 2, foram incubados por 6, 10 ou $24 \mathrm{~h}$ na presença ou ausência de $5 \mathrm{mM}$ de DTT crônico. As amostras foram analisadas quanto a fase do ciclo celular, por citometria de fluxo 
APÊNDICE D - Sincronização das células controles

Figura D.1 - Tentativa de sincronização dos linfócitos EBV com meio privado de SFB
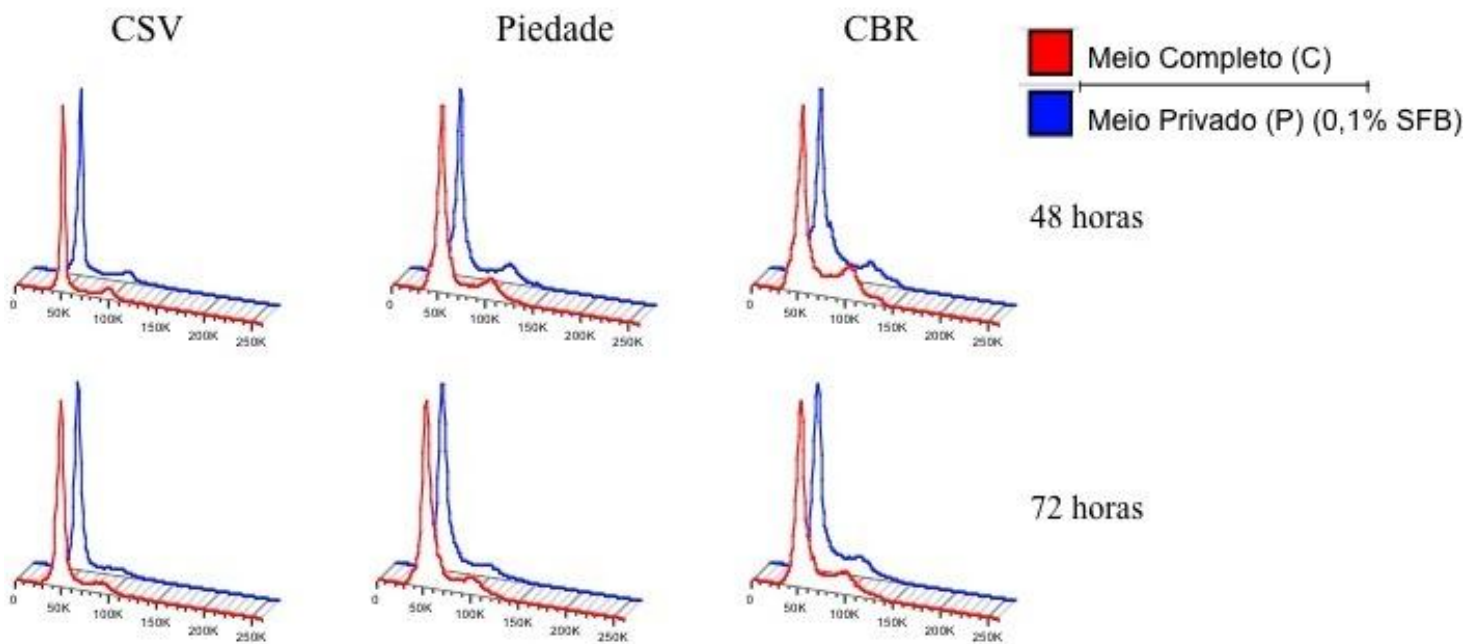

Tabela D.1. - Porcentagem de células em cada fase do ciclo celular

\begin{tabular}{|c|c|c|c|c|c|}
\hline Linhagem & tempo & Meio & $\% \mathrm{G} 1$ & $\% \mathrm{~S}$ & $\% \mathrm{G} 2$ \\
\hline \multirow{4}{*}{ CSV } & \multirow[t]{2}{*}{$48 \mathrm{~h}$} & $\bar{C}$ & 96 & 18 & $\overline{15}$ \\
\hline & & $\mathrm{P}$ & 82 & 21 & 10 \\
\hline & \multirow[t]{2}{*}{$72 \mathrm{~h}$} & $\mathrm{C}$ & 63 & 18 & 9 \\
\hline & & $\mathrm{P}$ & 72 & 14 & 9 \\
\hline \multirow{5}{*}{ Piedade } & \multirow[t]{2}{*}{$48 \mathrm{~h}$} & C & 51 & 19 & 15 \\
\hline & & $\mathrm{P}$ & 55 & 16 & 19 \\
\hline & \multirow[t]{2}{*}{$72 \mathrm{~h}$} & $\mathrm{C}$ & 45 & 36 & 8 \\
\hline & & $\mathrm{P}$ & 72 & 32 & 6 \\
\hline & $48 \mathrm{~h}$ & C & 36 & 28 & 16 \\
\hline \multirow[t]{3}{*}{ CBR } & & $\mathrm{P}$ & 37 & 33 & 14 \\
\hline & \multirow[t]{2}{*}{$72 \mathrm{~h}$} & $\mathrm{C}$ & 44 & 28 & 15 \\
\hline & & $P$ & 45 & 27 & 12 \\
\hline
\end{tabular}


Tabela D.2 - Tentativa de sincronização dos linfócitos EBV-B com meio privado de soro e nocodazol

\begin{tabular}{clccc}
\hline \multicolumn{1}{c}{ Meio } & Horas de Incubação & $\% \mathrm{G} 1$ & $\% \mathrm{~S}$ & $\% \mathrm{G} 2$ \\
\hline Meio Completo (C) $72 \mathrm{~h} \mathrm{C}$ & 64 & 22 & 9 \\
& $102 \mathrm{C}(72 \mathrm{~h}+30 \mathrm{~h})$ & 68 & 17 & 9 \\
& $72 \mathrm{~h} \mathrm{C}+30 \mathrm{~h}(\mathrm{C}+$ nocodazol $)$ & 60 & 15 & 18 \\
Meio Privado (P) & $72 \mathrm{~h} \mathrm{C}$ & 72 & 11 & 11 \\
& $102 \mathrm{C}(72 \mathrm{~h}+30 \mathrm{~h})$ & 70 & 15 & 7 \\
& $72 \mathrm{~h} \mathrm{C}+30 \mathrm{~h}(\mathrm{C}+$ nocodazol $)$ & 59 & 14 & 15 \\
\hline
\end{tabular}

